University of Louisville

ThinkIR: The University of Louisville's Institutional Repository

Electronic Theses and Dissertations

$12-2017$

\title{
The feelings we harbor - the role of collage in arousing powerful emotions in an ESL classroom.
}

Irina V. McGrath

University of Louisville

Follow this and additional works at: https://ir.library.louisville.edu/etd

Part of the Curriculum and Instruction Commons, and the Language and Literacy Education Commons

\section{Recommended Citation}

McGrath, Irina V., "The feelings we harbor - the role of collage in arousing powerful emotions in an ESL classroom." (2017). Electronic Theses and Dissertations. Paper 2849.

https://doi.org/10.18297/etd/2849

This Doctoral Dissertation is brought to you for free and open access by ThinkIR: The University of Louisville's Institutional Repository. It has been accepted for inclusion in Electronic Theses and Dissertations by an authorized administrator of ThinkIR: The University of Louisville's Institutional Repository. This title appears here courtesy of the author, who has retained all other copyrights. For more information, please contact thinkir@louisville.edu. 
THE FEELINGS WE HARBOR-THE ROLE OF COLLAGE IN AROUSING POWERFUL EMOTIONS IN AN ESL CLASSROOM

\author{
By \\ Irina $\mathrm{V}$. McGrath \\ M.A., University of Louisville, 2012
A Dissertation
Submitted to the Faculty of the
College of Education and Human Development of the University of Louisville in Partial Fulfillment of the Requirements for the Degree of

Doctor of Philosophy in Curriculum and Instruction

Department of Middle and Secondary Education University of Louisville

Louisville, Kentucky 
${ }^{\odot}$ Copyright 2017 by Irina V. McGrath

All rights reserved. 

THE FEELINGS WE HARBOR-THE ROLE OF COLLAGE IN AROUSING POWERFUL EMOTIONS IN AN ESL CLASSROOM

\author{
By \\ Irina V. McGrath \\ M.A., University of Louisville, 2012 \\ A Dissertation Approved on
}

November 13, 2017

by the following Dissertation Committee:

Lori Norton-Meier, Ph.D.

Kathryn Whitmore, Ph.D.

Mary Shelley Thomas, Ed.D.

James Chisholm, Ph.D. 


\section{DEDICATION}

To my daughters, Monica and Nicole-you are the lights of my life. 


\section{ACKNOWLEDGMENTS}

The journey of earning a doctorate degree is long and laborious. It takes years of hard work, will power, and commitment and is physically and emotionally demanding. Fortunately, a number of knowledgeable and caring people were by my side to help guide me through this journey.

I am tremendously grateful to all of you.

To my advisor and guiding light, Dr. Lori A. Norton-Meier, my deepest gratitude. Thank you for your kindness and your understanding, your support and your invaluable advice, and for giving me the strength to overcome my many challenges.

To Dr. Kathy Whitmore, whose influence shaped my dissertation topic and my beliefs, I am forever thankful for our priceless conversations; you gave me inspiration, provided me with amazing research opportunities, and furthered my knowledge-all of which deeply affected my work as a doctoral student and educator.

To Dr. Shelley Thomas, thank you for your encouragement and support, for believing in me, and for helping me realize the strength within myself to complete my dissertation journey and to create positive change in the education of English language learners. 
To Dr. James Chisholm, thank you for pushing me to go deeper into my thinking and for providing me with incredibly insightful and instrumental comments

To Jean Wolph—your friendship and mentorship have been invaluable to me throughout my life. Thank you.

Finally, to my mother and my daughters, whose unconditional love and nonstop support made this dissertation journey possible-l am grateful beyond words. 


\section{ABSTRACT \\ THE FEELINGS WE HARBOR-THE ROLE OF COLLAGE IN AROUSING POWERFUL EMOTIONS IN AN ESL CLASSROOM \\ Irina V. McGrath}

October 30, 2017

Traditional literacy education in the U.S. relies exclusively on language-based models. This can be particularly challenging for English language learners, who often find themselves bound by the constraints of the English language and limited in their expressions of thought and emotion. Current research on English language teaching, largely targeted towards native English-speaking students, suggests that incorporating various alternate modes of communication and representation improves literacy learning. Studies that address English language learning for non-native speakers are sparse. The purpose of this arts-based, qualitative, descriptive study is to fill this gap in the literature. Using collage making as a communicative mode, I conducted pre- and post-project, semistructured, ethnographic interviews with students and teachers. I used controlvalue theory to explore student artwork, and to analyze student emotion about collage making. Study results showed that collage was successful as a communicative mode in an English as a second language (ESL) classroom. Through collage, English language learners were able to express creativity, 
emotion, and language and to share stories. The collages were instrumental in the students' achievements, class participation, and feelings of self-satisfaction. 


\section{TABLE OF CONTENTS}

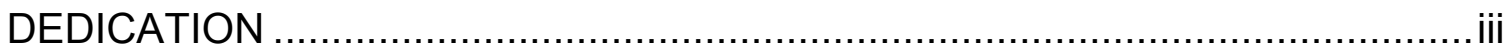

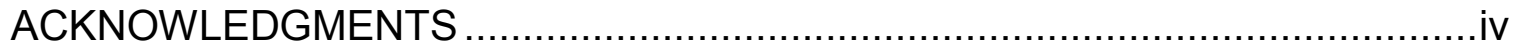

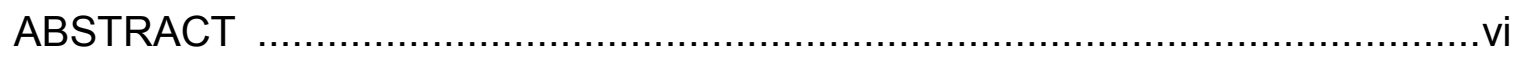

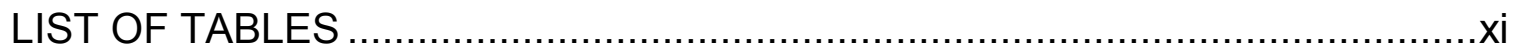

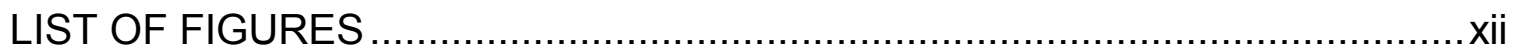

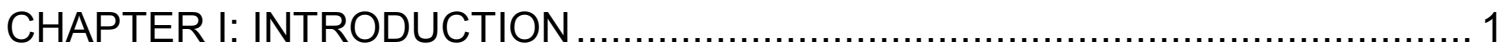

The Concept of Literacy and What It Means to Be Literate ….............................. 2

The Shifting Demographics of English Language Learners in the U.S............... 4

The Lack of Corresponding Change in English Language Instruction ................. 5

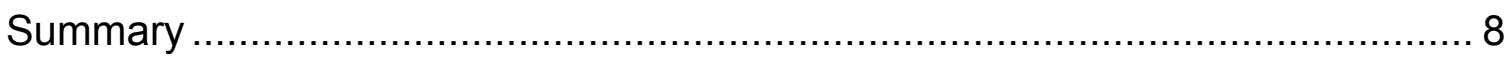

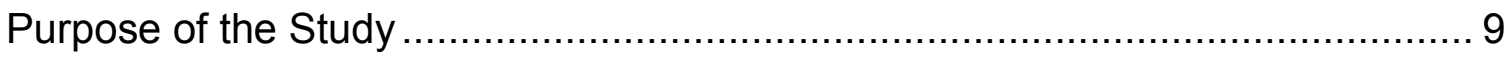

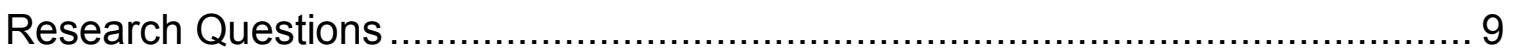

CHAPTER II: THEORETICAL FRAMEWORK ................................................ 10

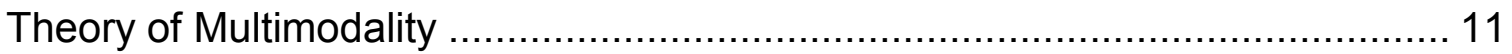

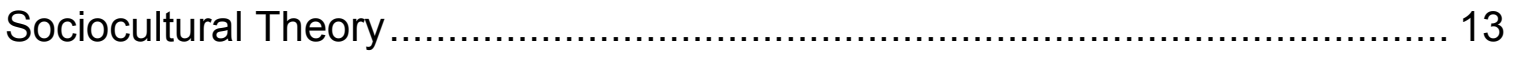

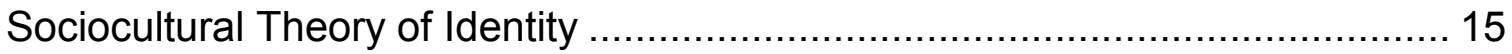

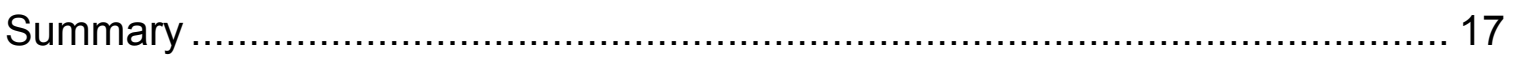

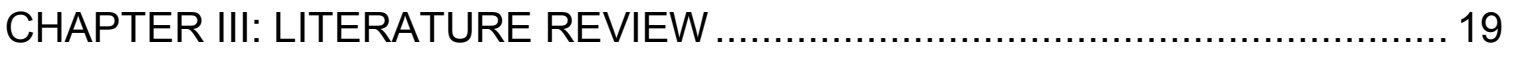

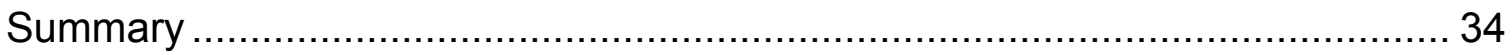

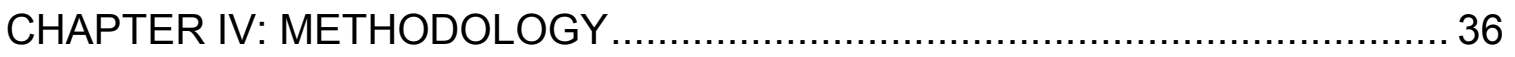




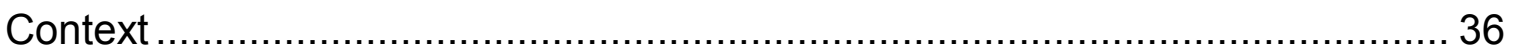

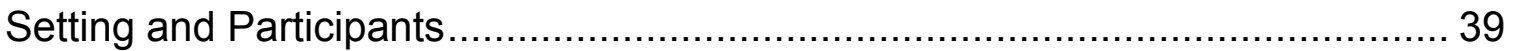

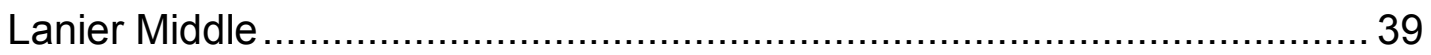

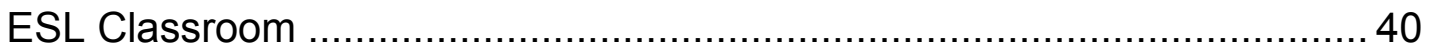

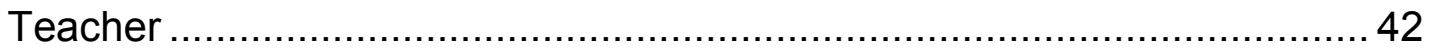

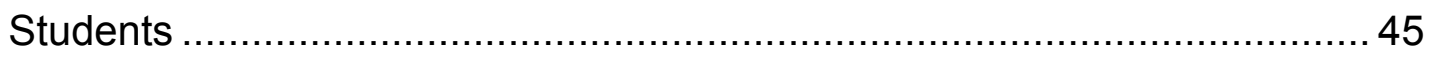

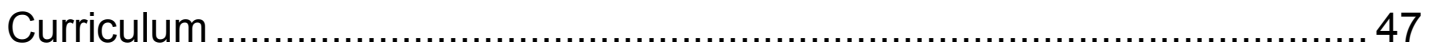

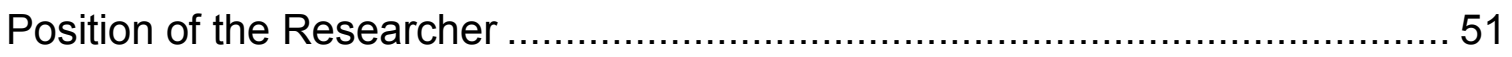

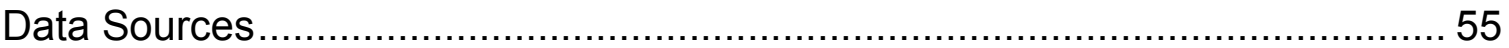

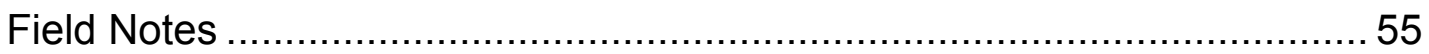

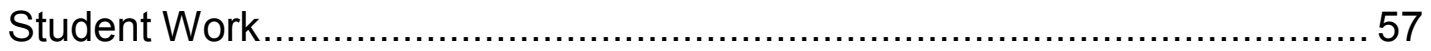

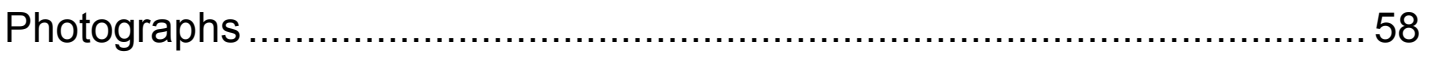

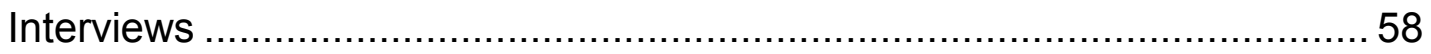

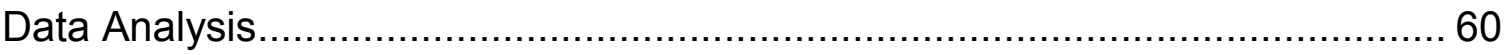

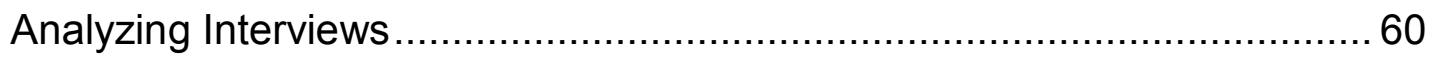

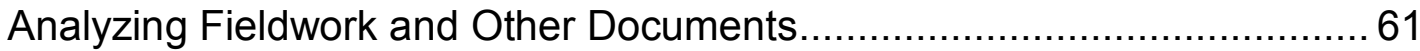

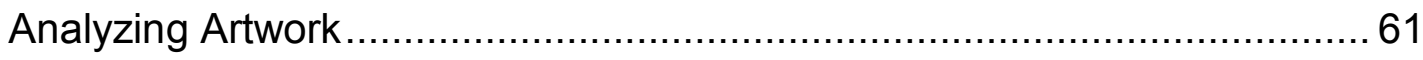

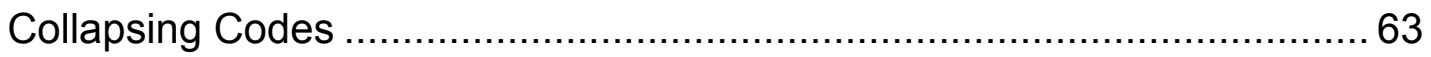

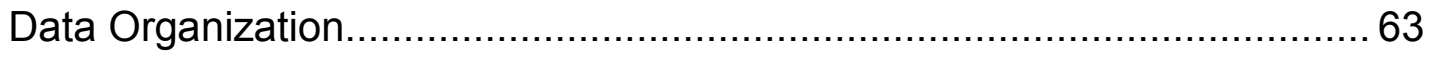

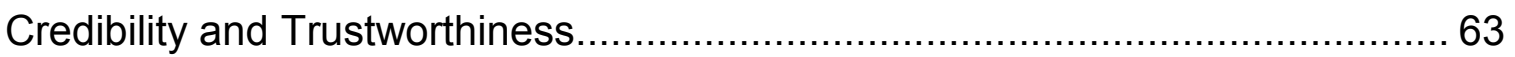

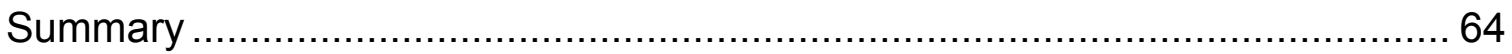

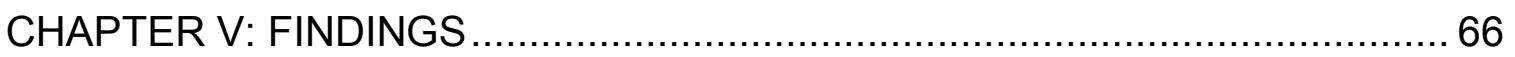

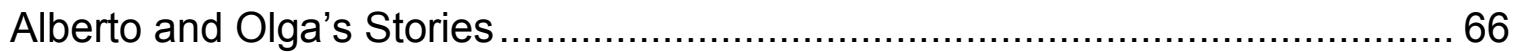




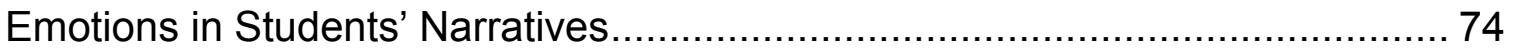

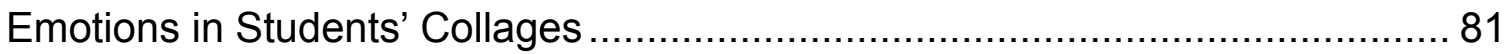

Achievement Emotions Related to Writing …….......................................... 99

Achievement Emotions Related to Collage Making .................................... 101

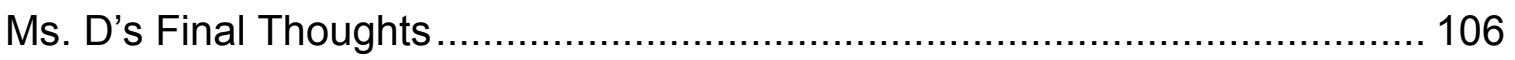

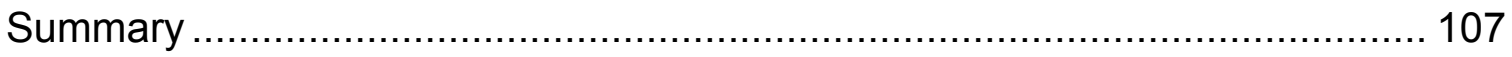

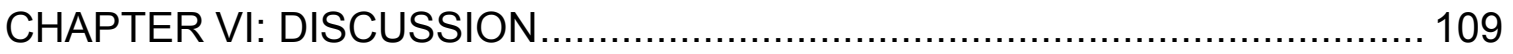

Creating Conditions for Effective Instruction for ELLs ................................ 114

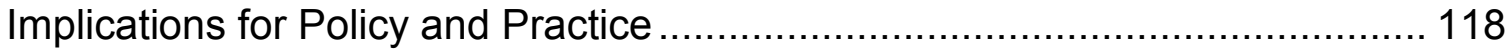

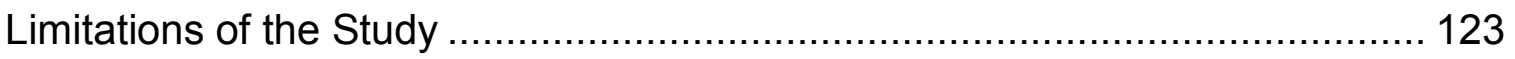

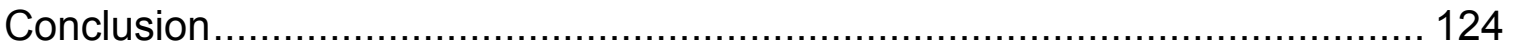

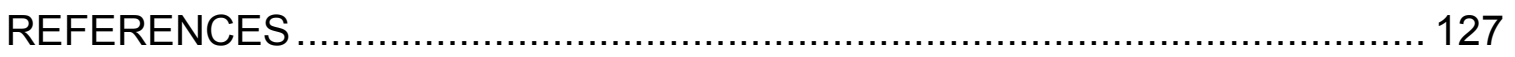

APPENDIX A: STUDENT INTERVIEW QUESTIONS ................................ 137

APPENDIX B: TEACHER INTERVIEW QUESTIONS ................................. 139

APPENDIX C: ORGANIZATION OF VISUAL TEXTS …............................ 141

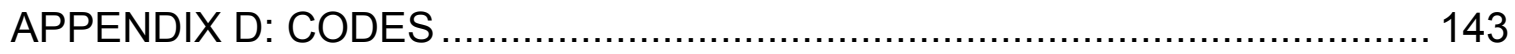

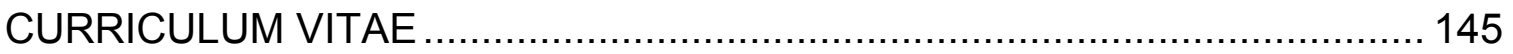




\section{LIST OF TABLES}

Table 4.1 Students' 2016 WIDA ACCESS Results...................................... 47

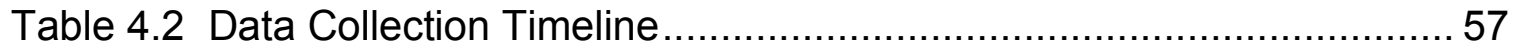

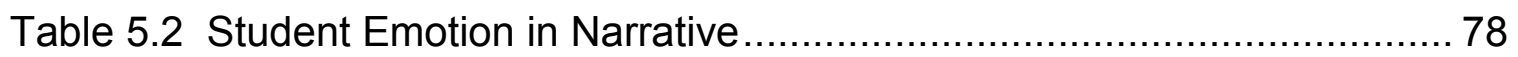

Table 5.3 Students' Explanation of Their Collages ........................................ 82

Table 5.4 What Color Meant in Students' Collages ....................................... 89

Table 5.5 Students' Thoughts and Feelings about Collage ........................... 102

Table 5.6 Students Who Preferred Writing over Collage Making ................... 104 


\section{LIST OF FIGURES}

Figure 5.1. Alberto's collage, representing his parent's separation. ................66

Figure 5.2. Olga's collage, representing her life in Russia............................ 72

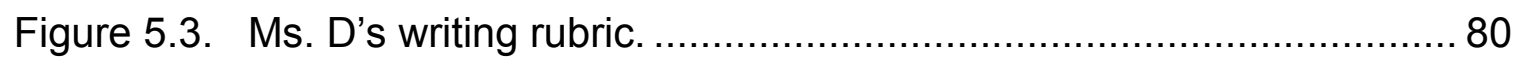

Figure 5.4. George's collage, depicting his move from Mexico to the U.S........ 90

Figure 5.5. Manuel's collage, depicting his move from Mexico to the U.S........91

Figure 5.6. Amal's collage, depicting a childhood accident. ..........................92

Figure 5.7. Chol's collage, depicting the house fire ....................................... 93

Figure 5.8. Yoselin's collage, about leaving Mexico for the U.S..................... 94

Figure 5.9. Vivian's collage, about her mother's death................................. 97

Figure 5.10. Maria's collage, about her parents' separation. .......................... 98 


\section{CHAPTER I: INTRODUCTION}

Eisner (2002) argued that, "Language, while a central and primary form of representation, is by no means the only form of representation" (p. 8). Albers (2007) agreed, stating that, humans can communicate not only through written and oral language but also through other sign systems, such as art, drama, music, math, and dance.

Unfortunately, for too long in the United States, "Language has been seen as the dominant way of knowing, particularly in the context of schooling, where oral or written language is thought to be the necessary precursor for acquiring knowledge" (Leland \& Harste, 1994, p. 337). Within this dominant educational practice, students become dependent on their ability to speak and write in English. This can be particularly challenging for newcomers to the U.S. and for English language learners (ELLs) who are at the entering level of English proficiency (WIDA, 2012).

There is little research on alternate strategies to support the academic and linguistic growth of language learners, and the studies that do exist, including research in the arts, multimodality, and 21st century literacies, do not involve English language learners. I conducted this study to fill this gap. Specifically, I wanted to examine the art form of collage in a secondary, English-as a-secondlanguage (ESL) classroom and to analyze the possibilities that collage making might offer as a communicative mode to these students. To put this study in 
context, I examined the concept of literacy and what it means to be literate, looked at the shifting demographics of English language learners in the United States, and studied the lack of corresponding change in English language instruction.

\section{The Concept of Literacy and What It Means to Be Literate}

The concept of literacy and the notion of what it means to be literate is complex. The multifaceted nature of both is evident in the numerous definitions that exist worldwide. For example, in the United States, literacy means the ability to read, write, understand, interpret, and discuss multiple texts across multiple contexts (International Reading Association [IRA], 2012). Other countries have different interpretations. Both the Netherlands and the German Federal Ministry for Economic Cooperation and Development define literacy as "reading and writing skills." The Swedish International Development Cooperation Agency defines literacy as "learning to read and write text and numbers" and, in Singapore, literacy refers to a person's ability to read with understanding. In urban China, a literate person is anyone who knows a minimum of 2,000 characters; in rural areas, it is 1,500 characters (Education for All Global Monitoring Report 2006, pp. 157-158). Within the U.S., the definition of literacy has undergone considerable change over the past three decades. Educators no longer view literacy as an individual practice but rather as a social one (Harste, 2003). James Paul Gee (1989), for example, viewed literacy as primary and secondary discourses, which are mastered through acquisition and learning. He believed that primary discourse came through "the process of primary 
socialization within the family" (p. 55) and that secondary discourses involved institutions beyond the family, such as schools, workplaces, stores, government offices, businesses, and churches (p. 56). Thus, these secondary discourses build upon and extend the uses of language that people acquire as part of their primary discourse. The secondary discourses develop, based on the practices that prevail within those institutions. Gee believed that it was important for all students, "mainstream and non-mainstream" (Gee, 1989), to acquire secondary discourses in a meaningful way.

Just as literacy is no longer considered an individual practice, it is also no longer described as a set of independent language skills that allows an individual to function in society, achieve one's goals, and develop one's knowledge (National Center for Education Statistics, 2003). Instead, many scholars and organizations are embracing the notion of multiple literacies. As Gee (2010) stated:

There are many different social and cultural practices which incorporate literacy, so, too, many different "literacies" (legal literacy, gamer literacy, country music literacy, academic literacy of many different types). People don't just read and write in general, they read and write specific sorts of "texts" in specific ways and these ways are determined by the values and practices of different social and cultural groups. (p. 4)

There is a relationship among literacy as a social construct, and the idea of multiple literacies and student literacy practices outside of school. There, students are immersed in "visual audio, and technology media [which they use] to capture, develop, produce, and publicly publish all types of products" (Albers \& Sanders, 2010, p. 2). They read online multimodal texts; communicate via Twitter, Snapchat, and Facebook; and participate in the Second Life ${ }^{\circledR}$, World of 
Warcraft ${ }^{\circledR}$ (Blizzard Entertainment, 2004), and other virtual worlds. However, although these practices may be part of the students' lives, they are not always integrated into school curriculum.

As Albers and Sanders (2010) pointed out, there is an existing tension between "the restrictive culture of political mandates that value[s] traditional approaches to literacy" and the need to develop "a culture of possibilities that engage[s] and build[s] upon the new literacies that students bring with them to class daily" (p. 2). Unfortunately, the data-driven, language-oriented curriculum, which privileges academic subjects and print-based literacy and marginalizes other ways of knowing, usually wins out.

\section{The Shifting Demographics of English Language Learners in the U.S.}

Throughout the United States, the population of English language learners has rapidly increased in recent years. Just in the past decade, states including Georgia, South Carolina, and Tennessee have experienced a growth greater than $200 \%$ in the ELL population (de Oliveira, 2016). In Kentucky, where I conducted this study, the ELL population jumped from 4,030 students in 20002001 to 16,351 in $2010-2011$-a 306\% increase (Horsford \& Sampson, 2013).

The increase in English language learners in the U.S. corresponds with the country's growth in immigrant and refugee populations. According to the American Immigration Council (2015), legal immigrants currently constitute 3.4\% of Kentucky's population, and unauthorized immigrants, roughly $0.8 \%$, representing a combined immigration increase of $2.5 \%$ from 1990 to 2013. 
The refugee population is also growing. Each year, between 60,000 and 85,000 refugees enter the United States (American Immigration Council, 2015). They may settle with or near their families or receive assistance through resettlement agencies. According to the Cultural Orientation Resource Center (2016), assistance organizations place refugees in areas, based on the availability of jobs, housing, and social services in the placement location. The Commonwealth of Kentucky, with its relatively low cost-of-living, job availability, and excellent social services, saw a $70 \%$ growth in refugee population between 2000 and 2012 (Kentucky Center for Economic Policy, 2014).

One of the many social service agencies in Kentucky is Catholic Charities; the organization provides programs for the elderly, immigration and naturalization consultations, employment, youth services, and free or low-cost legal services to refugees and immigrants. They also provide language assistance, interpretation services, and conduct free English as a Second Language (ESL) classes Monday through Friday from 9:30 AM to 3:30 PM (Kentucky Refugee Ministries, 2015). In addition to Catholic Charities, Interfaith Paths to Peace, Jewish Family and Career Services, and the nonprofit Americana Community Center also provide support to the English language learner community.

\section{The Lack of Corresponding Change in English Language Instruction}

In recent years, technology has become commonplace in everyday life. Younger generations communicate via Snapchat, Twitter, Instagram, and Facebook, and people of all ages spend numerous hours on their smart phones, computers, and tablets. These outlets are examples of passionate affinity 
spaces (Gee, 2004)—places where people "affiliate with others based primarily on shared activities, interests, and goals" (p. 67). These spaces are becoming increasingly more important to student identity development, education, and socialization than school environments. Whereas the outside world offers young people multiple communicative sign systems, classrooms continue to rely on one-language.

There are some exceptions to the language-only rule in elementary classrooms, where literacy education has shifted from conventional, textualbased tactics to include multimodal and digital methods (Albers, Holbrook, \& Seely Flint, 2014). The texts that students read and create in these classrooms are multimodal, multi-authored, and interactive (Jenkins, 2006) and contain written and spoken words, as well as images, graphics, and other digital enhancements. These changes are not as apparent in secondary school, which is a critical period when learning a second language. Indeed, researchers agree that "the window of opportunity for acquiring language within the language specific areas of the brain diminishes during the middle years of adolescence" (Sousa, 2011, p. 31) and decreases even further during high school years. According to Kissau, Adams, and Algozzine (2015), students who began learning a new language in middle school had greater oral proficiency, confidence, and motivation than students who started learning the language in high school. These findings are consistent with the instructional focus of many ESL teachers, whose goal is to help English language learners achieve cognitive academic language proficiency (CALP; Cummins, 1979) in five to seven years. Despite 
this knowledge, there is a demonstrable lack of improvement in achievement at this critical period, based on elementary and secondary scores on the National Assessment of Educational Progress (NAEP) test. According to a federal report (The Executive Office of the President, 2015), 11\% of fourth-grade ELLs in Kentucky scored at or above proficiency in reading and $19 \%$ of ELLs scored at or above proficiency in math. In contrast, only $5 \%$ of middle school ELLs scored at or above proficiency in reading and $1 \%$ scored at or above proficiency in math. Across the country, academic achievement for ELLs continues to "lag far behind [that] of their native English-speaking peers" (Carrillo Syrja, 2011, p. 9), and the gap between elementary and middle school ELLs remains wide.

National ELL statistics eventually drew the attention of the U.S. Department of Education (DOE) and the U.S. Department of Justice, Civil Rights Division (DOJ). On May 26, 2016, the U.S. Department of Education reauthorized the Elementary and Secondary Education Act of 1965 (ESEA). The reauthorized ESEA required that States' accountability systems "separately track and hold schools accountable for the performance of economically disadvantaged students, students from major racial and ethnic groups, children with disabilities, and ELs" (p. 4).

Additionally, the federal government issued a document warranting that all school districts and public schools were to ensure that English language learners participate meaningfully and equally in educational programs and services (U.S. Department of Justice \& U.S. Department of Education, 2015). To determine whether school districts complied with the civil rights laws, the Departments 
applied the standards established by the United States Court of Appeals for the Fifth Circuit in the Castañeda v. Pickard case (1981), as follows:

1. The educational theory underlying the language assistance program is recognized as sound by some experts in the field or is considered a legitimate experimental strategy;

2. The program and practices used by the school system are reasonably calculated to implement effectively the educational theory adopted by the school; and

3. The program succeeds, after a legitimate trial, in producing results indicating that students' language barriers are actually being overcome within a reasonable period of time. (p.6)

Finding a "sound program or a legitimate experimental strategy" for English language learners is not easy. This is in large part because existing research focuses on teacher recruitment and retention, Common Core State Standards, diversity, school safety, and early education (American Educational Research Association, 2016), and not on the economic and academic disparities the regulations were designed to address.

\section{Summary}

Research on English language learners and strategies that support these students' academic and linguistic growth is limited. Most studies on strategies, including research in the arts, multimodality, and 21st century literacies, center on those who already speak English. This study, however, specifically explored the impact of a single multimodal approach on the academic and linguistic growth of secondary English language learners. In particular, the study examined the role of collage as a communicative mode and the possibilities it offers to English language learners in secondary content classrooms. I discuss the underlying theory for the study in the next chapter. 


\section{Purpose of the Study}

The purpose of this study is to analyze the role that collages play in an English as a Second Language classroom and its value to English language learners as a communicative mode.

\section{Research Questions}

1. What can we learn about middle school English language learners from collage?

2. What role does collage play in an ESL classroom? 


\section{CHAPTER II: THEORETICAL FRAMEWORK}

It is more critical than ever for schools to acknowledge that the limits of our language do not define the limits of our understanding (Barone \& Eisner, 2012). When other modes of communication and representation, including the arts, "are pushed to the periphery of education politics and practices, then students are denied artistic methods and modes to develop and articulate their understandings, feelings, knowledges, experiences and perceptions" (McArdle \& Boldt, 2013, p. 5). When this happens, it deprives students of the opportunity to develop the creativity necessary for their personal and professional selfrealization and success. As Eisner (2002) argued:

[N]onlinguisic and nonquantitative forms of representation should be part of the programs that [teachers] design and, when it is warranted, to provide students with the option of displaying what they have learned in a field through video, film, and literary forms and through other means that suit the interests and aptitudes of the students they teach. The provision of such materials and opportunities makes a substantial contribution to education equity. (p. 205)

The use of nonlinguistic and nonquantitive forms of representation is particularly important for English language learners. Such forms provide English language learners with ways to learn and share what they know, which they can often not yet access through the English language.

Theoretically, I align myself with the ideas of Barone and Eisher (2012), Eisner (2012), and McArdle and Boldt (2013). Their ideas, coupled with 
multimodal, sociocultural, and identity theories, have influenced my thinking about equitable practices for English language learners.

\section{Theory of Multimodality}

The theory of multimodality (Hodge \& Kress, 1988; Kress \& Jewitt, 2003) addresses how people communicate, not just with language, but also with other forms of communication and representation. Multimodality does not sideline language; instead, it "nestles and embeds it within a wider social semiotic (Jewitt, 2008, p. 357). In a multimodal approach to pedagogy, teaching and learning happen through a range of modes, including images, writing, speech, and gestures (Archer \& Newfield, 2014). Learning takes place when students are "engaged in complex, socially constructed, personally relevant, creative composition and interpretation of texts that incorporate a variety of meaningful communicative modes or symbol systems" (Albers \& Sanders, 2010, p. 4). These modes, which Bezemer and Kress (2008) defined as "socially and culturally shaped resources for making meaning" (p. 170), "rarely, if ever, occur alone" (Jewitt \& Kress, 2003, p. 2). Instead, they work together in dynamic and synchronous ways (Eisner, 2002; Jewitt \& Kress, 2003; Albers \& Sanders, 2010). In some cases, certain modes may dominate, as in texts that use words and compelling visual images to convey messages. In other cases, the modes are equal. Regardless of the hierarchy, the processing of multimodal messages and texts requires certain skills on the part of the learner that are different from the skills needed to read print-based materials. Once developed, the skills expand the ways in which individuals acquire and comprehend concepts and provide 
learners with a broader range of options to obtain information (National Council for Teacher Education, 2005).

Kress and Jewitt (2003) identified four aspects that comprise a representation of meaning in the multimodal theory: materiality, framing, design, and production. Materiality refers to the materials or tools used to get the point across, such as photos, crayons, digital images, or music. Framing describes how individual elements within each mode make a message comprehensible and appealing to the audience. For example, a combination of images, words, and sound effects in a digital story must be well thought out, for the intended meaning to be conveyed as its author intended.

Design, the third aspect of multimodal theory, delineates the strategic positioning of elements within the chosen mode. When creating a collage, for example, an artist has to consider composition (the placement or arrangement of visual elements in a work of art). For instance, she may choose to position certain photos or images in the center of the piece, or she might move the pictures to the side and make them inconspicuous. Or, the artist may decide to incorporate angular lines into his design instead of rounded ones because "thick straight or angular lines convey anger, tension, frustration, and fear, while curved lines are more organic and soft and evoke a friendlier emotion" (Albers, 2007, p. 26). All of these decisions are a part of the design and are integral to communication between the artist and her or his intended audience.

In addition to "meaning-making that occurs through the reading, viewing, understanding, responding to ... and interacting with" (Walsh, 2010, p. 213) 
multimodal texts, learners actively design meaning through production, which is the fourth aspect of multimodal theory. Production encompasses the final product and the skills needed to design it. For example, to create a digital story, an artist must know about digital storytelling tools and be able to weave together images, music, voice, and/or words. If working on a group production, such as creating and performing a play, in addition to writing, performance, and creative problem solving skills, members of the group must have good communication skills and be able to work collaboratively with others. Understanding how various modes of communication and representation work allows individuals to communicate effectively with their intended audience (Jewitt \& Kress, 2003; Loerts, 2013). This knowledge of modes is essential to all students, particularly to English language learners, who often find themselves bound by the constraints of the English language. As Eisner (2002) pointed out:

The selection of a form of representation is a choice having profound consequences for [students'] mental life, because choices about which form of representation will be used are also choices about which aspect of the world will be expressed. Why? Because people tend to seek what they are able to represent. If your camera is loaded with black-and-white film, you look for shadows, for light and dark, but if the same camera is loaded with color film, you seek color. (p. 8)

\section{Sociocultural Theory}

Sociocultural theory is based on the concept that learning is a social process and that "human activities take place in cultural contexts, are mediated by language and other symbol systems, and can be best understood when investigated in their historical development" (John-Steiner \& Mahn, 1996, p. 191). Sociocultural theorists believe that the mind emerges from social interaction with 
other minds, that activities of "the mind are mediated by tools and symbol systems (languages), and that to understand a mental function, one must understand the roots and processes contributing to that function's development" (Unrau \& Alvermann, 2013, p. 67). Literacy learning is inseparable from the cultural and social histories of the individuals; therefore, an individual's construction of meaning is always influenced by their lived experiences.

Sociocultural theory was first proposed by Lev Vygotsky (1896-1934), a Russian psychologist, who strongly believed that biological, social, and individual factors are interconnected and that social interactions are essential to the development of cognition. Humans learn first through socialization with more knowledgeable peers (interpsychological level) and then through internalization of the gained knowledge, (intrapsychological level) (Vygotsky, 1978/1930-1934). During the early stages of development, learners rely on those who are more proficient in the subject matter. As they participate in a wide range of joint activities, the novice learners acquire useful strategies and crucial knowledge and become less dependent on others and more reliant on themselves. To help explain his position on learning as a social process and "to capture the relationship in schooling between what he called 'spontaneous' and 'scientific' concepts" (Moll, 2014, p. 35), Vygotsky (1978/1930-1934) developed the idea of a zone of proximal development (ZPD). According to Vygotsky, the ZPD was the

distance between the actual developmental level as determined by independent problem solving and the level of potential development as determined through problem solving under adult guidance or in collaboration with more capable peers. The zone of proximal development defines those functions that have not yet matured but are in 
the process of maturation, functions that will mature tomorrow but are currently in an embryonic state. (p. 79)

All learning takes place in a ZPD, where students' abilities are still

developing and can become manifested only with help from others (Moll, 2014).

As students participate in meaningful activities within their zones of proximal

development and synthesize the influences of others, they take on an increasing responsibility for their own learning and eventually become self-reliant learners (John-Steiner \& Mahn, 1996).

\section{Sociocultural Theory of Identity}

Sociocultural theory views identity as a social construct and considers human interactions to be the key factor in identity development (Mead, 1934; Erikson, 1994; Moje, Overby, Tysvaer, \& Morris, 2008; Vagan, 2011). The theory acknowledges that identities are lived out by individuals; however, "they are not individually constructed, produced, or possessed" (Moje \& Luke, 2009, p. 417). Rather, identities develop over time in social contexts, through interactions with others (Erikson, 1994). Historically, second language researchers working within the sociocultural theory distinguished between social and cultural identities. As Norton (2006) pointed out,

While "social identity" was seen to reference the relationship between the individual and the larger social world, as mediated through institutions such as families, schools, workplaces, social services, and law courts (e.g. Gumperz, 1982), "cultural identity" referenced the relationship between an individual and members of a particular ethnic group (such as Mexican and Japanese) who are considered to share a common history, a common language, and similar ways of understanding the world. (pp. 1-2)

Identity is no longer perceived as two separate entities; instead, second language researchers now view identity as socioculturally constructed and draw 
upon both social and cultural theories of identity in their work. According to sociocultural theory, identity construction is an ongoing process, "constantly changing across time and place" (Norton, 2006, p. 3). As immigrants and refugees move to a new country, they face the numerous challenges of everyday life. Adults have to find a job for themselves and a school for their children. They may also have to learn about U.S. currency, how to balance a checkbook, use a debit card, drive a vehicle, and navigate the healthcare system. Adults and children may have to learn a new language; this can be especially difficult for adults, as research shows that older you get, the harder it is to acquire a new language (Sousa, 2011). English language learners have to negotiate constantly between their own culture and the culture of the country that has become their home, and between their native language and English (Kanno, 2003).

Learning a new language is often associated with "the construction of new identities, appropriate to the new surroundings" (Pavlenko \& Lantolf, 2000, p. 171). As ELLs interact with English language speakers in various social settings, they start to appropriate their voices. Once they develop proficiency in their English, they rely less on the words of others and become more independent in using their new language in social and academic settings. Consequently, they develop a new voice that becomes their own, as well as a new identity (Pavlenko \& Lantolf, 2000). Proficiency in English is vital to the academic success and selfesteem of English language learners. The greater their language proficiency, the more comfortable ELLs feel about their abilities to perform academic tasks in English and the greater chance they have to develop an identity as a successful 
student. As Deme (2015) argued, "The lack of English language proficiency can threaten self-esteem and prevent students from self-expression, thus negatively affecting their academic identity" (p. 33).

Norton (2006) identified three additional characteristics of the sociocultural view of identity. The first is that classroom practices affect identity development; contemporary researchers, therefore, pay close attention to the interactive opportunities schools provide to students. As Norton and Toohey (2011) argued, "Diverse classroom practices offer learners a range of positions from which to speak, listen, read, or write. . . [Some] identity positions offer the greatest opportunity for social engagement and interaction [while others] silence students" (pp. 429-430). Educators, then, need to be aware of which practices support student identity development in a positive way and which ones marginalize students and contribute to their identities of struggling readers or writers and/or resistant learners (Moje \& Luke, 2009). The final two characteristics of identity that Norton (2006) defined were (a) that identity is "complex, contradictory, and multifaceted" and (b) that its "construction must be understood with respect to larger social processes, marked by relations of power that can be either coercive or collaborative" (p. 3).

\section{Summary}

Educational institutions continue to emphasize language over other modes of communication. For this reason, many ELL students feel constrained in language-only learning environments and struggle when performing activities in the classroom. Nonlinguistic and non-quantitative forms of representation, 
including arts-based modes of communication, have the capacity to assist and engage these students. However, these forms of communication have traditionally carried a lesser importance in education. Through continuing research and due to the growing prevalence of a multimodal world, nonlanguage-based modes are becoming more accepted in academic realms. Multimodality, which includes images, writing, and gestures (Archer \& Newfield, 2014), is an important concept for English language learning. In a multimodal approach, teachers combine writing with an artistic mode and present students with an engaging and non-linguistically-based activity, so that students feel more comfortable with a task, than they would with a strictly language-based activity. As students become comfortable in the classroom through their interactions with each other, they begin to form their own identities as learners. This is a key component of sociocultural theory, which views identity as a social construct and considers human interactions to be the key factor in identity development.

In the next chapter, I review the literature I consulted during my research, including studies about multimodality and identity-development in the classroom. 


\section{CHAPTER III: LITERATURE REVIEW}

In the past several decades, literacy practices in schools have been largely language-based (Dyson, 2001; Cummins, 2006; Kress, 2009).

Furthermore, according to Eisner (2002), "The dominant climate of... schooling [has been] one of highly rule-governed tasks and standardized expectations" ( $p$. 44). There has been a change, however, in the literacy practices outside of the school setting. As Albers \& Sanders (2010), stated, "Messages are now created, inscribed, sent, and received in multimodal ways steeped in the use of new technologies" (p. 1). Students are now able:

To participate in twittering, wikis, blogs or in various social networking sites (e.g., Myspace, Facebook, YouTube, Flickr); obtain instant information from the Web; or participate in a virtual environment through gaming or in a virtual world such as Second Life. (Walsh, 2010, p. 212)

These multimodal environments are changing the way in which students communicate and how they learn and process information. This is a problem for educators who continue to think of learning in terms of writing and speech (Jewitt, 2003). In her research on multimodal literacy and its implications for classroom use, Walsh (2010) discovered that more than $50 \%$ of students preferred computer games to reading or watching TV and that more than $40 \%$ of students used Photoshop, media players, or made podcasts at home. Despite these competencies, many students still have limited opportunities for multimodal 
literacy learning within the school setting (Tierney, Bond, \& Bresler, 2006; Walsh, 2009).

As schools continue to favor spoken and written words (Williams, 1983; Olshansky, 2008) over other modes of communication, language is still "the dominant way of knowing" (Leland \& Harste, 1994). Research shows, however, that nonlinguistic forms, when coupled with language, improve student literacy learning and level of engagement (Guichon \& McLornan, 2007; Early \& Marshall, 2008; Wei, 2011; Newfield, 2011). Vincent (2006) invited fifth graders at an independent primary school in Melbourne to create texts using MicroWorlds (LCSI, 2014) computer software, which improved the quality of student work and increased their engagement. The researcher concluded that:

Multimodal composition is not just a desirable extra, but should be brought into the mainstream of literacy teaching for two main reasons. Firstly, it is the way in which students see the world, and secondly it releases certain children from the trials of monomodal, verbal expression where they are unlikely to succeed. (Vincent, 2006, p. 56)

Hepple, Sockhill, Tan, and Alford (2014) documented similar results in a study of high school students whose "English language proficiency level . . . prohibit[ed] them from engaging fully with the literacy demands across the curriculum in mainstream classrooms" (p. 220). The researchers used Claymation and other modes of communication and representation and found that the multimodal approach was instrumental to student engagement and to the students' pride and satisfaction with their own work. At the middle school level, Ajaya (2009) found that multimodality gave students the opportunity to experience the writing process from different channels, enhanced their language and literacy learning, and allowed them to create new identities as experts. 
Similarly, in a study by Wilson, Chavez, and Anders (2012), middle school English language learners participated in an 18-week unit on identity, in which they used multiple modes of communication to respond to questions such as "Who am I?" "Where do I come from?" "Who do I want to be?" and "What do I value?" They read and analyzed picture books, wrote personal narratives about a special memory or a significant event in their lives, and created podcasts. The researchers concluded that the multimodal nature of the unit gave the English language learners the freedom to share ideas in a preferred way and, thus, enhanced their identities as learners.

Ntelioglou, Fannin, Montanera, and Cummins (2014) also found a connection between the use of multiple modes of communication and representation, and student identity development. In their study, the researchers examined the effects of multilingual and multimodal practices on the literacy learning of English language learners. The study took place in a Canadian, $\mathrm{K}-8$ inner city school, which included a large population of linguistically and culturally diverse students. The researchers invited students to write narratives in multiple languages, use digital technological tools to add images and sound effects to their stories, and then turn the stories into dramatic performances. The researchers found that using additional modes of communication helped students express themselves, particularly those students who were at the beginning levels of English proficiency and who "normally felt embarrassed about their lack of spoken language fluency" (Ntelioglou et al., 2014, p. 6). Drama practice became central to the revision stage of the writing process because the students were 
able to act out what they were trying to convey. Finally, the multimodal and multilingual classroom practices allowed students to access identity positions of experts, which further increased their literacy learning (Ntelioglou et al., 2014). The review of research on multimodality and identity development revealed the potential that multiple modes of communication provides for positioning students as learners and experts in the classroom. Black (2009) studied adolescent English language learners and online fan fiction and discovered that the use of multimodal forms of representation furthered students' learning and encouraged their "participation in linguistically sophisticated and cognitively demanding tasks" (p. 695). In that study, as English language learners joined an online community to create fan fiction texts, they immersed themselves "in creative manipulation of popular cultural and textual artifacts, drawing from a mixture of text, image, color, and sound as a means of representing themselves and communicating in online spaces" (p. 690). By doing so, students were able to practice their writing skills and participate in collaborative activities that allowed them to feel a sense of accomplishment and to take on powerful identities of successful learners, collaborators, and technology experts.

Norton (1997) supported the notion of identity as a social construct and stressed the influential role of classroom interactions on students' identity development. According to Norton, identity relates to a learner's desire for affiliation, security, and safety. She stated that, "People who have access to a wide range of resources in a society will have access to power and privilege, 
which will in turn influence how they understand their relationship in the world and their possibilities in the future" (Norton, 1997, p. 410). Norton (2010) used the term investment to explain a learner's relationship to a second language:

If learners invest in a second language, they do so with the understanding that they will acquire a wider range of symbolic and material resources, which will in turn increase the value of their cultural capital. As the value of their cultural capital increases, so learners' sense of themselves, their identities, and their opportunities for the future are reevaluated. Hence, there is an integral relationship between investment and identity. (p. 3)

When students participate in activities that support their growth and allow

them to feel a sense of accomplishment, they become more engaged with a task and, consequently, more invested in their own work (Norton, 1997; Norton \& Williams, 2012). Student investment in work comes with a sense of ownership (Norton, 2003). In Norton's (2010) study on identity, literacy, and English language learners, the researcher used photography as a tool for female high school students to explore their lives and to develop proficiency in English. Throughout the project, Norton asked the participants to study the manuals on how to use the cameras and take quality pictures, write in their research journals, and participate in group discussions and class presentations. Norton found that the students had "complex investments in their respective literacy practices" ( $p$. 7), which resulted in high levels of English competence. Norton (2010) concluded that:

When learners engage in literacy practices, they are also engaged in acts of identity... If learners have a sense of ownership of meaning-making, they can engage actively in wide range of literacy practices; however, if there is little ownership over meaning-making, learning becomes meaningless and ritualized. (p. 10) 
Literacy researchers have recognized the importance of various modes for expanding options for students' writing in the classroom through the use of technology (Bogard \& McMakin, 2012) and visual literacy (Ranker, 2009). In a one-year qualitative study, Wiseman, Makinen, and Kupiainen (2015) investigated the integration of photography, drama, art, and writing in an elementary language arts curriculum. The findings demonstrated how various modes "alongside traditional school literacies, such as writer's workshop" (p. 537) benefited students, as they had more options to explore content and show their learning. Groves (2011) challenged the current view of the writing process taught in primary classrooms and urged teachers to employ a multimodal approach and to "use technology to enhance students' creative possibilities in the construction of new and dynamic texts and build learning about the elements of design into their instruction" (p. 49).

Brouillette, Burge, Fitzgerald, and Walker (2008) looked at the benefits of integrating writing instruction into visual and performing arts classes. In this study, visual arts, music, and dance teachers were paired with language arts teachers to create model lessons for others to use and/or adapt to meet their students' needs. In these lessons, both English language speakers and English language learners engaged in writing-to-learn activities, which became "a major component of student exploration of the arts" (p. 23). One of the activities, quickwrites, "allowed students to focus on what they wanted to say, recording their thoughts without stopping to worry about grammar and punctuation" (p. 20). Collaborative activities gave students frequent opportunities to share ideas with 
each other and to theorize, question, and examine their thinking before revising their quick-writes and turning them into essays. To test the effectiveness of the approach, the researchers collected writing samples from the students whose teachers participated in it, as well as the students in the control group whose teachers did not participate. The researchers found that the combination of writing-to-learn and arts-based activities had a profound effect on the students' academic growth. Both subgroups, English language speakers and English language learners, showed significant gains in writing.

The work of other scholars and practitioners has demonstrated the value of the visual arts as an entry point to academic writing. At the college level, Stein (2000) used photography to help her undergraduate ESL students write essays. Each pair of English language learners was asked to capture, in 14 photographs, literacy practices at various sites, and then create a captioned display, before writing an academic paper describing the findings. Stein concluded, "The use of visual mode as a sensory and cognitive activity enable[d] many students who struggle[d] with writing to produce more logical, coherent written texts" (p. 335). Olshansky (2016) created two approaches to literacy learning: Image-Making within the Writing Process and Picture Writing: Fostering Literacy through Art. Both approaches treated visual images and written words as equal modes of communication within the Artists/Writers Workshop. The workshop was designed around three basic premises:

(a) pictures are a natural language for thinking, developing, and expressing ideas; (b) not all students work easily with words; and (c) if we are truly interested in supporting the literacy learning of all students, we would be wise to expand the range of thinking tools we provide in the 
classroom, especially for our emerging or struggling readers and writers. (Olshansky, 2016, p. 109)

During picture writing, children created picture books by studying quality examples of picture books first. They learned how authors and artists use words and images to create a story. Then the children drew pictures to tell their own stories and used written words to describe the pictures. Similarly, during image making, children were invited to generate portfolios of textured papers (such as bubble, sponge, and watercolor paintings) and use them to create collages. Afterwards, the children wrote stories by "reading" their artwork. When they were done writing, the students typed their final drafts and glued them to the back of the collages.

Frankel (as cited in Olshansky, 2008) investigated the effectiveness of Olshansky's (2008) picture writing process. In Frankel's study, three hundred seventy-seven first- and second-grade students from three New Hampshire school districts participated in the study. Students' writing samples were collected from the treatment and comparison groups and retyped to prevent any bias on the part of the scorers. Frankel found that there were "significant gains in students' story development and use of descriptive language in the treatment group, as compared to smaller, or no gains, made by students in the comparison group" (Frankel, as cited in Olshansky, 2008, p. 188). This process was particularly successful with students who found academic writing challenging and who needed to have an alternative pathway to entering texts.

In a recent, four-year study, Frankel, Olshansky, and Yang (2015) evaluated the effectiveness of both image making and picture writing models. 
Three elementary schools in the Manchester School District served as the treatment group and three others, as the control group. Additionally,

two self-contained ELL Magnet programs within [the district] also served as treatment and comparison groups for evaluating the impact of the enhanced model on the academic achievement of this unique population of immigrant and refugee students new to the country. (Frankel, et al., 2015, p. 4)

Fifteen hundred students participated in the study. Eighty teachers in the treatment schools implemented the Picturing Writing/Image-Making Integrated Curriculum models, while the teachers in the comparison group implemented writing programs used in their schools. The authors found there were significant gains in writing and visual literacy

for treatment students at all grade levels as compared to the demographically matched comparison group. This held true for all at-risk subgroups as well, including 'Below Benchmark Readers,' Special Education Students, ELL Mainstream Students, and ELL Magnet Students. (Frankel, et al., 2015, p. 27)

Similar to Olshansky, Ehrenworth (2003) used visual images to teach writing to her students. She asked her students to analyze portraiture and record their observations; she then had them transform the phrases and sentences into poems. Ehrenworth's study documented the role that visual arts played in the writing process. She concluded that using more than one mode of communication and representation allowed students to access the experiences of others, as well as to "describe their own experiences and their ways of looking at the world" (p. 47). Batchelor (2014) examined the changes in seventh-grade advanced placement students' writing and the changes in their attitudes and perceptions regarding the revision process. For thirteen weeks, Batchelor co- 
taught a unit that focused on writing flash fiction and flash science fiction; during this time, the students free-wrote in writing journals, participated in a writers' workshop, discussed numerous revision techniques, and used mentor texts to learn how to "read like writers." At the end of the unit, the students produced three pieces of writing. After completing each piece, Batchelor asked students to reread the pieces in class and transfer their work into a different mode, such as 3-D art, sculpture, or drawing. Next, the students were encouraged to revisit their initial drafts and revise them. The findings of the study indicated that using another mode of communication allowed students to "visualize and see their writing concretely in front of them, which allowed opportunities for them to think about adding to their drafts while revising" (p. 221). The students reported that, by the end of the unit, they thought they could write better and also felt that the revision process could "be an enjoyable aspect of writing." The researcher concluded that, "teaching revision does not need to be confined to a languagedominated point-of-view, but rather, it could include other modes of communication" (p. 5).

Learning environments are complex and can be affected by physical space, materials and technology, classroom activities, and emotion. Emotions influence students' identity development and control their motivation (IAE, 2014).

For example, students can be excited during studying, hope for success, feel pride in their accomplishments, be surprised at discovering a new solution, experience anxiety about failing examinations, feel ashamed over poor grades, or be bored during lessons. In addition, social emotions play a role as well, like admiration, empathy, anger, contempt, or envy concerning peers and teachers. Moreover, students bring emotions to the classroom that concern events outside the school, but can nevertheless have a strong influence upon their learning, such as the emotional turmoil produced by stress within the family (Pekrun, 2014, p. 6). 
Emotions drive attention (Sylwester, 1994) and consequently affect students' engagement or disengagement with an activity or task. Thus, they contribute to students' successes and failures in a school setting and have a profound effect on their future, including their career goals and aspirations.

Despite the significant role emotions play in the field of education, their impact on students' lives and academic achievement has been largely overlooked. Only in recent years have emotions come back into the focus of researchers; however, the topic has still remained largely understudied.

The word emotion is defined as an affective state of consciousness and comes from the Latin word emovere, which means "to move out." The term has been frequently used in different disciplines in the humanities and the social and behavioral sciences; however, the questions, "What is an emotion?" and "What is the origin of human emotions?" "rarely generate the same answer from different individuals, scientists or laymen alike" (Scherer, 2005, p. 696).

Historically, there have been several views on emotions and their origin. One view is that an emotion is a feeling. According to Ahmed (2014), Descartes viewed emotions as feelings of bodily changes, stating that, "Emotions do not involve processes of thought, attribution or evaluation: we feel fear, for example, because our heart is racing, our skin is sweating" (Ahmed, 2014, p. 5). James (1902) also viewed emotions as feelings, stating that "the general cause of the emotions are indubitably physiological" (p. 449).

Another view is that emotions are tied to cognition. Ahmed (2014) stated that Aristotle and his followers believed that emotions were tied to "involve[d] 
appraisals, judgements, [and] attitudes" (p. 5). Lastly, there are scholars who believe that emotions are the product of human cognition and physiology.

Despite their origin, emotions are inseparable features of human nature and, unlike feelings, can be inferred and even measured empirically. According to Scherer (2005):

While both nonverbal behavior (e.g. facial and vocal expression) and physiological indicators can be used to infer the emotional state of a person, there are no objective methods of measuring the subjective experience of a person during an emotion episode. Given the definition of feeling as a subjective cognitive representation, reflecting a unique experience of mental and bodily changes in the context of being confronted with a particular event, there is no access other than to ask the individual to report on the nature of the experience. (p. 712)

Students' emotions can be inferred through facial and auditory expressions, and their intensity will vary from student to student and from one situation to another (Sylwester, 1994). Student-teacher conversations and teacher observations can identify and/or confirm the types of emotions students experience as well as their intensity. Educational theories and research on emotions can shed the light into causalities of emotions and their impact on student learning. One of the theories that specifically focuses on emotions in education is the control-value theory of achievement emotions (Pekrun, 2000; Pekrun, Frenzel, Goetz, \& Perry, 2007). Reinhard Pekrun (2014). Professor and the Chair for Personality and Educational Psychology at the University of Munich, advocated for four groups of academic emotions: epistemic, topic, social, and achievement. Epistemic emotions "are emotions triggered by cognitive problems, such as surprise about a new task; curiosity, confusion and frustration about obstacles; and delight when the problem is solved' (p. 8). An example of 
epistemic emotions as they relate to cognitive activities could be a student disappointed in his inability to either solve an algebraic expression or write a physics' lab report. The key is in the student's focus. If the focus is on the "cognitive incongruity implied by a non-solved problem" (Pekrun \& LinnenbrinkGarcia 2012, p. 262) then the student experiences epistemic emotions. If the focus is on personal failure then the student experiences achievement emotions.

Topic emotions are triggered by topics of classroom activities. These types of emotions do not necessarily relate to learning but nevertheless, they affect students' interests and engagement. An example could be emotions experienced by English language learners as they read and discuss refugee experiences that are similar to their personal experiences.

Social interactions are central to any academic setting. As Pekrun \& Linnenbrink-Garcia (2012) stated, "academic learning is situated in social contexts. Even when learning alone, students do not act in a social vacuum; rather, the goals, contents, and outcomes of learning are socially constructed" ( $p$. 263). Consequently, social emotions are emotions triggered by students' interactions with fellow students as well as teachers and administrators. These interactions induce an array of emotions in students from admiration and respect to annoyance and frustration and consequently influence student engagement. When social interactions among students evoke positive emotions, students are more likely to continue work with each other. When social interactions lead to students experiencing negative emotions, student disengagement may occur. 
Similarly, students' emotions towards teachers can either promote or demote engagement.

Finally, "achievement emotions are defined as emotions tied directly to achievement activities or achievement outcomes" (Pekrun, 2006, p. 317). Achievement activity emotions occur at a specific time before, during, or after students participate in an activity. These emotions can be a one-time experience or they can become habitual and reoccur each time a student participates in a recurring activity. An example of an activity emotion could be the joy that a student experiences every time he participates in a writing or reading activity.

The two types of achievement emotions: activity emotions and outcome emotions, differ in the object's focus. In activity emotions, the focus is on the activity itself; in outcome emotions the focus is on the outcome of a specific activity. The control-value theory differentiates between two types of outcome emotions: prospective and retrospective. Outcome prospective or anticipatory emotions are evoked before the activity begins. Students' anticipation of certain outcomes of an activity can lead to them either experiencing excitement that the desired outcome will be achieved or feeling anxious about an activity. Outcome retrospective emotions are evoked after the activity has been completed-for example, students feeling pride and satisfaction in the work well-done or experiencing embarrassment that the outcome of an activity turned out to be not what they had hoped for. 
Control and value are two important variables of the control-value theory, and their appraisals determine the type and intensity of emotions. According to Pekrun, et al. (2007):

appraisals of control and values are central to the arousal of achievement emotions, including activity-related emotions such as enjoyment, frustration, and boredom experienced at learning, as well as outcome emotions such as joy, hope, pride, anxiety, hopelessness, shame, and anger relating to success or failure. (Pekrun, 2006, p. 315)

In control-value theory, there are two types of subjective values: intrinsic and extrinsic. Intrinsic values represent students' appreciation for the activity itself, whereas extrinsic values suggest students' appreciation for an activity because they see how the activity relates to and helps them achieve future goals (Pekrun et al, 2007). For an activity to evoke emotion, an individual must first conduct an appraisal of both control and value. Different combinations of these appraisals lead to different emotions:

If the activity is seen as being controllable and valued positively, enjoyment is instigated. For example, if a student is interested in some learning material and feels capable of dealing with this material, he will enjoy studying... If there is controllability, but the activity is negatively valued, anger is posited to be experienced... In contrast, if the activity is valued, but there is no sufficient control and obstacles inherent in the activity cannot be handled successfully, frustration will be experienced. Finally, if the activity is valued neither positively nor negatively, boredom is induced. (Pekrun, Frenzel, Goetz, \& Perry, 2007, p. 21)

An appraisal of an activity does not necessarily happen on a daily basis.

For the most repeated or ongoing activities in a classroom, students conduct the control-value appraisal once and the emotions induced by that specific activity become habitualized. As Pekrun, et al. (2007) stated, "A student who has had many positive experiences in a class can experience anticipatory enjoyment 
before entering the classroom, without any need for an elaborate processing of expectancies and values relating to attending the class" (p. 23). However, every new situation will require a new appraisal.

\section{Summary}

In recent years, the importance of various communication modes has grown significantly; content classrooms, however, continue to preference language as the dominant mode of communication and representation. And even though a number of studies have demonstrated the positive effects of the visual arts on English language learners' academic growth and language development, very few studies discuss the role of collage as a communicative mode and the possibilities it offers to ELLs in content classrooms. Similarly, educational research on emotions, even though still in its emerging stage, has revealed a link between emotions and academic achievement. However, few studies discuss the role of emotions and explore their impact on English language learners' academic growth and language development. Additionally, the studies that do exist focus mostly on achievement outcome emotions and not activity emotions (Pekrun \& Linnenbrink-Garcia, 2012).

In the next chapter, I discuss the methodology for the study of 13 eighthgrade students who participated in an ESL program and used collage making, in addition to writing, to share personal stories with teachers and peers. I describe the study's context, setting, and participants, and detail the collection, analysis, and organization of the student and teacher interviews, fieldwork documents, 
artwork, and other data. I also discuss the various techniques I used throughout the study to establish credibility and trustworthiness. 


\section{CHAPTER IV: METHODOLOGY}

\section{Context}

I conducted the study in an ESL classroom at Lanier Middle School, in one of the largest school districts in the southeastern United States. At the time of the study, the district provided ESL services to 5,706 students who spoke English as an additional language. Of these students, 3,631 attended 41 elementary schools, 845 attended nine middle schools, and 1,230 attend 10 high schools. The district also offered services to new students at the International Academy and the ESL Newcomer Academy. To receive ESL services, students had to obtain the status of Limited English Proficient (LEP).

LEP classification in Kentucky is similar to schools across the U.S. School districts first administer a home language survey to identify students with limited English proficiency (703 KAR 5:070) (Kentucky Department of Education, 2016). Kentucky's home language survey contains four questions:

1. What is the language most frequently spoken at home?

2. Which language did your child learn when he/she first began to talk?

3. What language does your child most frequently speak at home?

4. What language do you most frequently speak to your child?

If the language is something other than English, then the school is required to assess the child to determine whether he or she is proficient in English or qualifies as an English language learner. To determine the student's 
classification, Kentucky uses the WIDA-ACCESS Placement Test (W-APT).

Based on test results, students are classified as Limited English Proficient (LEP) or Initially Fully English Proficient (IFEP). Under the reauthorized ESEA /No Child Left Behind Act (No Child Left Behind [NCLB], 2002), parents must be notified that their child has been identified as LEP, within 30 days of the beginning of the school year and within two weeks for students that enroll during the school year (Zacarian, 2012). The school must also develop a Program Services Plan (PSP) that outlines each student's instructional and assessment accommodations and indicates which of the following services the student will receive:

- Content-Based ESL: English Learners receive instruction in the content area of English language arts from a certified ESL teacher.

- Sheltered English Instruction: English Learners receive instruction in mainstream classrooms. Content is taught in English and adapted to the student's English proficiency levels.

- Structured English Immersion: English Learners receive support in the general education classrooms from an ESL teacher or bilingual associate instructor.

- Content Area Tutoring: English Learners receive one-on-one or small group tutoring during school hours in the content areas of language arts, mathematics, science, and social studies. 
- Two-way Immersion: English Learners and English Speakers receive instruction in both English and the primary language of the EL students.

- Pull-out ESL Resource: English Learners are removed from the general education classes to receive instruction in academic content or English language skills.

The services are determined by the Program Services Plan (PSP) committee and vary from student to student. If parents decline ESL services, the student will not participate in an ESL program but may still receive instructional and assessment accommodations in content area classrooms. If parents accept the ESL services, the student will be assigned to his or her assigned school (or to the closest school that offers an ESL program) and will receive instructional and assessment accommodations in content area classrooms.

Those students who are in their first year of enrollment in U.S. schools attend either the International Academy or the ESL Newcomer Academy until they reach a composite score of 2.5 or higher on the WIDA-ACCESS test. The test is administered to all English language learners in January and February of each year and results are made available to schools in May. Upon meeting the exit criteria, the newcomer students are assigned to schools by district, or to the closest schools that offer an ESL program. 


\section{Setting and Participants}

\section{Lanier Middle}

At the time of the study, Lanier was one of 20 middle schools in the district that served sixth through eighth grade students and one of nine middle schools that offered an ESL program. The school had approximately 900 students who spoke seventeen languages, including English; 126 students were classified as LEP. $52.3 \%$ of the students were male and $47.7 \%$ were female. $48.5 \%$ were White, $26.6 \%$ were African-American, $18.7 \%$ were Latino, $3.2 \%$ were Asian, and $2.6 \%$ were classified as "Other." $12.1 \%$ of the students participated in the Exceptional Child Education program, which was designed to meet the needs of students labeled as having various disabilities, including mild mental disability, emotional-behavioral disability, and multiple disabilities. Nine percent of the students participated in the ESL program. The school was located south of the city, within a low socioeconomic neighborhood; the average home value was $\$ 75,000$ and the household median income, approximately $\$ 30,000$. Most of the students lived within the school zone, aside from a small group of students who were bussed in from other neighborhoods because schools in their areas did not offer ESL programs.

Lanier had the second highest Spanish-speaking middle school population in the district; Spanish was second only to English as the most spoken language. The school employed two ESL teachers who spoke English only, one ESL teacher who spoke English and Spanish, one Bilingual Associate Instructor who spoke Spanish and provided translation support to students who were at the 
entering level of English proficiency (WIDA, 2012). English language learners at Lanier traveled together with English speakers to Math, Science, and Social Studies classrooms and split into two groups for Language Arts. English learners whose parents did not waive ESL services received English Language Arts (ELA) instruction from a teacher certified to teach ESL while English speakers received ELA instruction from a Language Arts teacher. Due to the split, both ESL and non-ESL classrooms were small, with approximately 13 students in each class.

For many years, Lanier Middle was an Environmental Education magnet. Students accepted into the program received intensive instruction in human interactions with nature and participated in outdoor investigations and projects. This is changing, as the school's focus shifts to promoting positive school culture and academic achievement. In October 2015, Lanier Middle was named a Cambridge International School of Excellence and began implementing the Cambridge Advanced Program into all its Advanced Placement classes. Although none of the English language learners in the building participated in the Cambridge program, at the time of the study, the school was also considering adopting the ESL version.

\section{ESL Classroom}

Ms. D's room was located on the second floor of Lanier Middle School, directly across from the computer lab, where the students often worked. Upon entering the classroom, my sight immediately fell on the bookshelves-two $6.5 \mathrm{ft}$. bookshelves, each with all five shelves completely filled with books of every size and genre for students to peruse and check out. To the right of the bookshelves 
were two bulletin boards: one had yellow background paper and festive, multicolored ribbon and the other was blue with a green border. There were school related news stories and flyers on the yellow board and, on the blue one, word walls of current vocabulary words, a calendar for the date, and a large map of the United States. Laid out in the middle of the room were four circular dark wood-coated tables, accompanied by twenty lightly colored, maroon chairs. On the wall across from the entrance and close to the ceiling were seven small, rectangular windows that let light trickle into the classroom. Below the windows was a row of tidily placed computers and seats. There were ten orange stability yoga balls under the long computer table; I found out later that students could use these if they preferred them to regular chairs. Ms. D was one of three teachers in the building who purchased the balls so she could offer her students this choice-during class activities, they could sit passively at a desk or bounce on a ball. The inflatable balls were light enough for the students to pick up and carry to their desks and were big enough so they could rest comfortably on them and not have to worry about sliding off. When I started the study, the balls had been in the room for nearly a year and the students had decided on their sitting preferences. Those who enjoyed the balls knew the classroom expectationthey were to pick up a ball from under the computer table and put it back once class was over. They always followed this rule.

One of the largest pieces of technology in Ms. D's classroom was the interactive Smart Board whiteboard, located on the right wall. Ms. D attached her computer and document camera to the Smart Board and used the board daily to 
present new information and review previously learned content. She also used it to take notes. Occasionally, Ms. D incorporated educational games into her teaching and used the Smart Board to display the games and allow students to interact with technology. Directly below the Smart Board were short bookcases that were filled with textbooks, dictionaries, and encyclopedias. Ms. D's desk sat in the corner of the room, diagonal to the doorway and adjacent to the Smartboard, with the gleaming light falling on the papers on her desk. Opposite Ms. D's well-ordered desk, was Mr. S' desk. Mr. S was an ESL teacher who collaborated with Mr. D during first and fifth block and used Ms. D's room to teach seventh-grade ESL students during Ms. D's planning period.

The whole classroom was illuminated by the bright and cheery colors of the many posters that lined the walls and was spatially organized in a way that promoted student engagement and facilitated learning. The students had a variety of classroom resources that were readily available to them, comfortable seating that promoted group activities and encouraged discussion among peers, and technology that bolstered education in an increasingly advanced world.

\section{Teacher}

Ms. D had been teaching at Lanier for six years, since they started their ESL program; for the five years prior to that, she taught Spanish at a Catholic school. When Ms. D started at Lanier, she was teaching ESL classes for all three grades (sixth, seventh, and eighth). As the number of students in the program increased, the Principal hired two additional ESL teachers. Ms. D became a teacher leader and mentor and continued to teach two sixth-grade and 
on eighth-grade class. She told me on numerous occasions that what she enjoyed the most was seeing growth in students and getting them excited about learning. In one of our conversations, she said,

Students are most happy when you have an engaging activity for them to do or an engaging curriculum, whether it be the story that you are reading or the activity on a Smartboard. They love to be involved, and they love to show you what they know, and they love to ask questions. They really love learning even though they won't tell you that. I noticed that they get the most excited when you get excited with them and you have something that interests them and that they can connect with. .

Therefore, Ms. D made it her goal to include as many stimulating and meaningful activities into her teaching as possible.

Ms. D was a strong believer in using various communicative modes in her ESL classroom, but she had not felt this way in the beginning of her teaching career. Her strong feelings towards incorporating visual arts into her teaching developed over time. Just as many ESL teachers at the secondary level did, she considered language to be the main mode of communication and representation. Ms. D centered all of the classroom activities and projects on developing ELLs' English proficiency through written and oral language. She made sure that her students practiced reading, writing, speaking, and listening skills on a daily basis. Ms. D participated in art courses when she was in middle and high school and once in college and had enjoyed them tremendously but had never associated visual arts with a language arts curriculum. When Ms. D first started teaching, she incorporated art into her lessons mostly so that her students could analyze someone else's work, rather than create their own. In her initial interview, Ms. D mentioned that all of her ESL endorsement courses in college favored language and the term 'visual arts' was associated with an accommodation for ELLs and 
not with a communicative mode that students can use to express themselves and share their learning. Ms. D's first introduction to multimodality happened two years ago when I approached her with an idea to co-teach a unit focused on students' lives and experiences. The unit's guiding question was: What do you want your teachers to know and understand about you? English language learners were asked to write a letter to their teachers and share a memory that would help teachers to get to know them better. In addition to writing, the students created collages. I selected collage-making instead of asking students to draw a picture using crayons or color pencils because of the students' fear of drawing. From my conversations with middle school ELLs, I learned that they viewed their drawing skills as inadequate and many refused to draw even a stick figure. Collages, on the other hand, were a more manageable activity for the students. They liked searching through magazines and cutting out pictures and words. By the end of the unit, Ms. D's students shared their excitement about the collage-making activity and displayed pride in the final product. Our conversations and students' written reflections revealed that collage-making became one of the most exciting and helpful activities for them. Ms. D was impressed by the quality of her students' work, and she was amazed at how two different modes, language and collage, allowed her to learn so much more about the students. Ever since that year, Ms. D has been incorporating collages into her 6th and 8th grade curriculum. However, between the two grade levels, Ms. D believed that 8th graders "were more mature to express themselves through collage than her 6th graders" and that they could appreciate more of what 
collage-making had to offer. I purposefully selected Ms. D's classroom for my study because I knew she would be using collage with her eighth graders. When I approached her about conducting my research in her classroom, she enthusiastically said yes.

\section{Students}

Thirteen eighth-grade English language learners participated in this study, seven males and six females. The students' English proficiency levels varied greatly; this was due to factors such as how long the student had been in the United States, family literacies, prior schooling, and age of arrival. For example, seven students had come to the United States more than eight years ago, four had arrived five to six years ago, and two students immigrated to the United States less than two years ago Eight of the students spoke Spanish; the remaining spoke Dinka (1); Nepali (1); Russian (1); Somali (1); and Swahili (1). The participants were representative of the greater school population in terms of gender and language.

All students in Ms. D's class qualified for free lunch and participated in the free after-school tutoring programs offered by the school and a local community organization called the Adelante Hispanic Achievers. Adelante was a non-profit organization that offered academic, mentoring, and personal enrichment programs to Spanish-speaking students and their parents. Through the partnership, established several years before the study, Adelante's volunteers provided one-on-one tutoring services to Spanish-speaking students in Lanier's 
library on Wednesdays and Thursdays from 2:30 until 5:00 PM, and Lanier provided transportation home.

The state of Kentucky uses WIDA ACCESS assessments to determine proficiency levels for English language learners. WIDA was originally established in 2002 when Wisconsin, Delaware, and Arkansas (WDA) were awarded an Enhanced Assessment Grant to develop language proficiency standards and assessments for the identification and correct placement of students who speak English as another language. When Arkansas decided not to participate in the grant; WDA changed to World-class Instructional Design and Assessment (WIDA). Kentucky joined WIDA in 2006 and has been administering the WIDA W-APT assessments to all students who are new to the U.S. and who may qualify for ESL services. The state also uses the WIDA ACCESS test with all students who have been previously identified as LEP to determine the students' English proficiency levels in reading, writing, listening, and speaking.

Additionally, the test provides teachers with information needed to create the students' Program Services Plans and to determine whether ELLs are ready to exit the LEP status. Lastly, test data helps school districts determine the effectiveness of their ESL programs and to identify other areas of need.

ACCESS for ELLs is administered in January through early February of each year and the results are available the following spring. WIDA distinguishes between the following proficiency levels: 1-Entering, 2-Emerging, 3-Developing, 4-Expanding, 5-Bridging, and 6-Reaching (WIDA: SPRING 2017, Interpretive Guide for Score Reports Kindergarten-Grade 12, p. 9). Table 4.1 shows the 
students' results in four of these areas. These numbers along with the students' names, languages they speak, and the dates the students were identified as Limited English Proficient exemplify the data that ESL teachers get to see before they meet their students in person in the fall.

Table 4.1

Students' 2016 WIDA ACCESS Results

\begin{tabular}{|c|c|c|c|c|c|c|}
\hline \multirow[b]{2}{*}{ Student } & \multirow[b]{2}{*}{ Language } & \multirow[b]{2}{*}{$\underline{\text { LEP ID }}$} & \multicolumn{4}{|c|}{ ACCESS } \\
\hline & & & Reading & Writing & Speaking & Listening \\
\hline Alberto & Spanish & 2008 & emerging & developing & developing & developing \\
\hline Maria & Spanish & 2008 & emerging & expanding & bridging & expanding \\
\hline Vivian & Swahili & 2015 & bridging & developing & bridging & bridging \\
\hline Marco & Spanish & 2008 & emerging & developing & expanding & developing \\
\hline Isabel & Spanish & 2008 & developing & developing & emerging & developing \\
\hline Yoselin & Spanish & 2016 & entering & entering & entering & entering \\
\hline Fatima & Somali & 2012 & developing & developing & developing & emerging \\
\hline George & Spanish & 2011 & developing & expanding & reaching & bridging \\
\hline Manuel & Spanish & 2009 & developing & expanding & reaching & bridging \\
\hline Olga & Russian & 2011 & expanding & expanding & reaching & expanding \\
\hline Ernesto & Spanish & 2008 & developing & developing & bridging & developing \\
\hline Amal & Nepali & 2012 & emerging & developing & emerging & expanding \\
\hline Chol & Dinka & 2008 & entering & developing & developing & expanding \\
\hline
\end{tabular}

\section{Curriculum}

Narrative writing was an essential part of the middle school language arts curriculum. Each year, all students in the district, including English language learners, were required to produce a piece of writing that described a real or imagined event. According to Ms. D, her students struggled with this assignment, even though she tried to scaffold instruction and break it down into manageable pieces. Ms. D had administered a writing pre-assessment to her students, during which students were asked to respond to a prompt and to use narrative techniques to describe events from their past. The pre-assessment 
results confirmed the ACCESS state test: all but four students in class were either entering or developing their writing proficiency. Additionally, on a learning survey that Ms. D administered at mid-term, 50 percent of the class responded that they needed to improve in writing. The writing attitude survey indicated that the majority of students did not like writing and had a negative viewpoint of their writing ability. Ms. D saw the need for quality writing instruction and a task "that would provide an avenue for success and give English language learners a sense of personal accomplishment and efficacy." Consequently, Ms. D decided to add a collage making to the unit. She was hoping that it would provide English language learners with a unique and exciting way of sharing a story and give them a break from having to rely constantly and exclusively on the English language. Her plan was for students to create a draft of a story, spend a few days working on the collages, and then return to the stories for revisions and edits, and to type them on the computers. In her initial interview Ms. D said,

My unit has a language and content objective. My language objective is for students to use reading, listening, speaking, and visual literacy to increase their writing proficiency on the WIDA writing rubric. My content objective is centered on the students' knowledge of Common Core State Standards (CCSS) W 8.3, which requires them to write narratives about personal experiences. By the end of the unit I want my students to be able to communicate their thoughts and feelings to an intended audience through two modes of communication-writing and collage. I think that these modes will make learning accessible to all my kids no matter their English language proficiency level.

Ms. $\mathrm{D}$ began the unit by talking to her students about their memories and by reading aloud from Wilfrid Gordon McDonald Partridge (Fox, 1984). She shared personal essays written by professional authors, including those from Dear Bully: 70 Authors Tell Their Stories (Kelley Hall \& Jones, 2011) and 
discussed picture books, including Let's Go See Papa (Schimel, 2011).

Afterwards, the students talked with partners and in small groups about why the authors chose to share their stories with the audience and the impact of the events on the main characters' lives. Ms. D's goal was to activate the students' prior knowledge; as they started making personal connections to stories of others, she hoped they would be able to generate ideas for their own narratives. After the students shared, Ms. D asked each of them to make a list of five to seven memories about life events that had a bearing on who they had become as individuals; then she encouraged them to share them in small groups. Ms. D was confident that feedback from classmates and the classmates' interest in certain memories would help students decide which stories to write about. She conferred with several students who had a difficult time choosing what to focus on. Once everyone finalized their ideas, Ms. D turned on calming music and asked the students to write their first drafts.

For the next two weeks students focused on writing. Ms. D's lessons had a predictable structure, which helped ELLs with transitions from one activity to another. English language learners knew exactly what happened in the lesson first and what activity followed next. Each class period, during a warm-up activity, Ms. D invited her students to either respond in writing to a prompt displayed on the Smartboard or edit a paragraph from a textbook. She would purposefully retype it using incorrect grammar and punctuation and then ask her students to correct errors. Independent work was always followed by volunteers sharing their responses with the class; afterwards, the class would move on to 
reading and discussing a mentor text. Then Ms. D taught a mini-lesson on a narrative technique and used a mentor text again to show how that technique was used by a professional writer. From the mini-lessons the students learned about similes, metaphors, and personification, how to embed dialogue and descriptive language into their writing, and how to "explode the moment"-a technique created by Barry Lane (1998), a well-known writer and educator. Ms. D explained each technique and actively engaged her students in practicing what had been taught, then she would link it to the students' narratives and encouraged them to go back to their drafts and apply the new learning to their own work.

By week three, the drafts were complete, and Ms. D started focusing on the arts. The students learned that there were five basic art elements that made up all objects in the world—dots, circles, lines, curves, and angles— and that artists used various types of lines to evoke emotions. As Albers (2007) explained, "Thick straight or angular lines convey anger, tension, frustration, and fear, while curved lines are more organic and soft and evoke a friendlier emotion" (p. 26). The students discovered that the composition or arrangement of visual images in a work of art is essential to how the artist conveys the message and how the audience receives it.

Ms. D decided that the best way for her students to understand what she expected from them during the collage activity, was to share some collages that professional artists and former students of hers had created. Using Microsoft PowerPoint images, she showed the students an individual collage and then 
asked them to apply their knowledge of colors, lines, and shapes to analyze the message of each piece of art. The students used their writer's notebooks to document their initial thoughts and then worked with partners to discuss ideas and confirm their findings. Students volunteered to present their thoughts to the class. Ms. D made sure that everyone agreed on the collage's message, before she introduced the next image. She continued the process until she felt that the students had acquired the necessary skills to read other artists' collages.

The next step was for the students to create their own collages. To get them started, Ms. D asked her students to bring photos from home. She scanned the photos using a school scanner, printed them in color, and returned the originals. Then, she gave them magazines and scissors so they could choose and cut images and letters from the magazine and gave them big zip-lock bags for their cuttings. She gave each of the students a piece of $9 \times 9$ white card stock paper to build their collages on and warned them not to glue anything until they carefully thought through the positioning of their chosen images. Ms. D personally met with each student about his or her collage; after they explained the collage's composition, she gave them glue sticks. Students spent the first three days of week four making final revisions and editing drafts. On Thursday and Friday, they typed their narratives in the computer lab across the hall.

\section{Position of the Researcher}

To conduct this study, I had to set aside my identity as a resource teacher who helps with lesson planning, provides feedback on the effectiveness of instruction, and co-teaches. Instead, I took on the identity of a researcher who 
was in the classroom every day for five weeks to collect data, including field notes, student work samples, and interviews. I did not start out as a participant observer; I interacted closely with Ms. D and her students, yet I did not participate in any of the class activities. However, as Merriam (2009) stated:

In reality, researchers are rarely totally participants or total observers. Rather, there is often a mix of roles wherein one might begin as either a full participant and then withdraw into more of a researcher stance or, in reverse, begin as a total observer and become more of a participant over time. (p. 125)

As the study progressed, even though Ms. D never asked her students to confer with me, one by one, completely on their own, they started to approach me with questions about spelling and grammar. Soon their questions turned into requests to listen to their stories and give them feedback regarding various narrative techniques they were incorporating into their writing. A student asked me to read her draft and to let her know if her descriptions of people and places were vivid enough and if the story was comprehensible. Another student asked me to read the lead to his story and share my opinion on how effective he was at making it engaging. He wanted to make sure that he hooked the audience in the beginning of the narrative, so they would continue to read it. I definitely began my work "as a spectator and gradually [became] involved in the activities being observed" (Merriam 2009, p. 126). However, even when Ms. D or the students asked me to participate in the activities, I tried "to stay sufficiently detached to observe and analyze" (Merriam, 2009, p. 126).

The narrative unit and student conversations made me think about the events in my past that had an impact on my life and who I had become. Like the participants of the study, I was an English language learner. Unlike the middle 
schoolers in Ms. D's classroom, I arrived in the United States at a much older age. My first language is Russian and when I was 25 , I left Russia to teach my native language at a high school level in the U.S. I had studied English in elementary, middle, and high school as well as college, but upon moving to the United Sates, I immediately realized that learning a second language did not necessarily equal knowing it.

I vividly remember my arrival in the Chicago O'Hare airport. Exhausted from a 14-hour non-stop flight, the passengers of II-96-300 formed a line and slowly proceeded to the exit. I found myself squeezed between an older woman wearing a bright red Versace dress and a young couple in faded jeans and tshirts. The crowded aisle of the Russian plane was my last connection to home. It felt safe and strangely comfortable. I wanted to hold on to that feeling forever, but I knew that it would be impossible.

Clenching my bag tightly, I passed by the smiling faces of the flight attendants and stepped into the unknown. The airport was buzzing with noises that I could not differentiate. The sounds of human voices mixed with those of moving bodies, carts, and escalators. Hundreds of people were passing by me in a hurry. Everyone seemed to know what they were doing and where they were going. Overwhelmed and terrified of the new surroundings, I stopped in the middle of a terminal, staring at signs that meant nothing to me.

"I cannot go back, only forward," I told myself, as I looked around for any visuals to help me find my way to the Greyhound bus. The signs in English had arrows next to them but they were pointing in many directions and none of them 
looked like a picture of a bus. I tried to understand what people around me were saying, only to realize that my listening skills were not strong enough to comprehend the conversations. There was no point in trying to talk to anyone. Even if I were able to produce an intelligible question, I wouldn't be able to understand the answer. Whether oral or written, language was out of the picture. My only hope was that, eventually, I would spot an image of a vehicle that would guide me out of the labyrinth of terminals. I didn't see any but what did catch my eye through the glass wall was a yellow taxi cab parked outside. I knew then that I would be able to get to the Greyhound bus safely.

During my first several months in the U.S., I discovered painfully the power that language was holding over me. When asked a question, I had an indepth answer in my head but my lack of proficiency in English prevented me from sharing it with others. Constant translation from English into Russian and back brought on severe headaches and frustration with my inability to communicate fully. I soon realized that my personality started to change-I was becoming more reserved. "You are not saying anything," people would remark in a conversation. "I don't know enough words to say what I want to say!" I wanted to tell them but instead I would only smile. It would take too much time to explain why I was quiet, and I wasn't sure they would be able to understand me anyway, both literally and figuratively.

Despite the challenges that language was imposing on me, I soon realized that other modes of communication were there to support me and help me feel confident again. Gestures became invaluable in my attempts to get points 
across. Visuals helped with making sense of the world around me. It was much easier to learn English vocabulary and comprehend texts when pictures or illustrations were included alongside words. It was less painful to get around the city and accomplish daily tasks when I relied on images, graphics, and photos. Facial expressions and tones of voice helped me share my emotions, I as I read the emotions and feelings of others. I became acutely aware of how people reacted to language. Certain words in a conversation would make their eyes sparkle or cast a barely noticeable shadow. Paying attention to how others responded to the content of a conversation and the choice of words used in that conversation helped me to understand people better.

The first several months in the United States taught me an invaluable lesson that language, though the dominant mode of communication and representation, was only one of many modes; and that the overreliance on language can have an irreversible effect on your emotional well-being as well as your self-esteem and motivation.

\section{Data Sources}

I collected and analyzed data over a three-month period, from March to May 2017. My data sources included field notes, student work, photographs, and interviews. See Table 4.2 for my data collection timeline.

\section{Field Notes}

Before beginning to collect data, I visited Ms. D's classroom to become familiar with classroom routines, rules, and expectations. When she began teaching the narrative unit, I took field notes (Sunstein \& Chiseri-Strater, 2012), 
documenting exactly what I observed. Each day, I began my field notes with the same format. I included the date and time of each observation and listed the participants present (Merriam, 2009). If a student or students were absent on any particular day, I noted that in my notes as well. I used the checklist suggested by Merriam (2009) to guide me. In my field notes, I described in detail:

- The physical setting of Ms. D's classroom, as well as technologies and resources available to the students.

- Information about the participants of the study, where they were sitting, what they were doing, and their reactions to what was happening in the classroom.

- Interactions between the students during various cooperative learning activities and interactions between the students and the teacher. During whole class discussions, I wrote down direct quotes from the participants as well as summaries of their utterances. Whenever students worked in small groups, I used voice recorders to record group conversations and transcribed them later for an in-depth analysis of what they said. This data helped me to see who generated what ideas as well as to understand the reasoning behind certain decisions the students made when creating collages.Personal, reflective comments that described my feelings, reactions, and emerging theories; I used these later to write memos. As Glesne (2011) suggested: 
Recording only observations and interview notes in your field journal is not enough. As often and as soon as possible, reflect on your fieldwork so you can clarify and add to them. If you do not reflect on your fieldwork, what was clear to you in September will not necessarily be so in December. Writing helps you think about your work, and about new questions and connections. (p. 189)

At the end of each period, I shared my notes with Ms. D. The timing worked well for both of us. She taught English Language Arts (ELA) to her eighth-grade ESL students during second period, followed by a planning period. Looking through my field notes benefited both of us. Ms. D helped me interpret what was happening in the classroom and she used my field notes to reflect critically on her teaching and student learning.

Table 4.2

Data Collection Timeline

Date Action Data

March, 2017 Became familiar with the site Interviewed the teacher and the students and transcribed the interviews District and school data Student data Initial interviews Performed initial data analysis

Memos

April, 2017- Did fieldwork

May, 2017 Completed data collection Conducted final interviews and transcribed them Performed data analysis Conducted peer-reviews Did member checking

Field notes

Students' drafts and reflections

Students' final writing pieces

Students' collages

Follow-up interviews

\section{Student Work}

Throughout the study, I collected various artifacts, including narrative drafts; final pieces; collages; and the writer's notebooks that students used to 
take notes, write responses to Ms. D's prompts, and reflect on their learning. Additionally, I collected the students' notes that described their experiences with the arts-based unit. Ms. D had asked the students to think about the past four weeks chronologically and describe in writing what they did, what they thought, and how they felt. The students' responses reflected their personal perspectives and helped me better understand their attitudes and feelings towards writing and collage.

\section{Photographs}

I took photographs of the students as a "means of remembering and studying detail that might be overlooked if a photographic image were not available for reflection" (Bogdan \& Biklen, 2007, p. 151). The photographs helped me remember details about the day and the students' facial expressions helped me interpret their responses to the different parts of the narrative unit.

\section{Interviews}

I conducted multiple informal interviews and two in-depth, semi-structured interviews with the students and Ms. D. I conducted the semi-structured Interviews with students before and after the arts-based narrative unit. In the first such interviews, I sought to learn about the students' interests, their attitudes towards writing and collage, and their comfort levels with writing in English (see Appendix A). To create a relaxing and trusting atmosphere, I started by talking to the students about their prior experience with writing and collage making. I hoped this would establish a relaxed environment that would lower the students' affective filter (Krashen, 1982) and allow them to open up to me and freely share 
their thoughts about experiences. Affective filter refers to the learner's psychological state of mind and affects the amount of language students are able to understand and, consequently, the amount of language they are able to produce. When English language learners experience negative emotions such as anxiety or alienation, their affective filter is high and it impedes the input and output of information. The more relaxed and comfortable the students are the more control they have over the language and its functions. Therefore, just as it was imperative for Ms. D to lower her students' affective filters to ensure language acquisition, I too wanted to do this, so I could maximize what I learned from students during my interviews.

I interviewed the students again immediately after the completion of the arts-based unit. As soon as the students finished typing their stories in the computer lab, Ms. D sent them, one at a time, to meet with me. It was our fifth week together and by then the students felt comfortable responding to my questions and sharing their experiences. I was mostly interested in their experiences with collage making and wanted to hear them talk about the images, colors, and lines they had used to communicate their stories. I also wanted to know what strategies or activities they had found to be most helpful, engaging, or challenging, and why. Since I was looking for specific information from all of the participants in the study, I asked everyone some questions; however, "the largest part of the interview [was] guided by a list of questions or issues to be explored, and neither the exact wording nor the order of the questions [was] determined ahead of time" (Merriam, 2009, p. 90). 
In my semi-structured interview with Ms. D, I focused on her professional history and her experiences with the writing process and the arts as a student and as an educator. I also wanted to learn more about her experiences and feelings about integrating collage into her teaching, as well as the strategies and activities she felt were most successful (see Appendix B).

I recorded all of the semi-structured interviews to "ensure that everything said [was] preserved for analysis" (Merriam, 2009, p. 109) and I subsequently transcribed them.

\section{Data Analysis}

I analyzed the data "simultaneously with data collection" (Merriam, 2009, p. 171). I began by looking at the school data I had obtained from the Kentucky Department of Education website as well as the student data from Ms. D and the ESL office. Through these sources, I learned the students' entry dates into the United States, which languages they spoke, their educational background, and their English language proficiency levels. My analysis of interview data, collages, and students' narratives were shaped by what Pekrun (2014) referred to as achievement and topic emotions and by Pekrun, Frenzel, Goetz, \& Perry's (2007) concepts of control and value.

\section{Analyzing Interviews}

I transcribed the interviews with the students and with Ms. D. I listed when, where, and with whom I conducted them. Then I added line numbering down the left-hand side of each page and left a wide margin on the right-hand side for comments and codes. Consistent with Vagle (2014), I did a holistic 
reading of an entire text, or the first read, of the data. I read to get a general feeling for the data but did not make any notes or assign codes. Next, I read line by line and did open coding. I looked for significant statements across the interviews and tried to identify parts that related to my research questions. I eliminated statements that were not relevant to my research questions.

\section{Analyzing Fieldwork and Other Documents}

As I started to accumulate field notes and documents from the study, I looked in the data for the codes I had created for the interviews and I created new ones. I created a separate list of codes for each piece of data I analyzed. Afterwards, I compared my lists and combined them, thus creating "one master list of concepts derived from [several] sets of data. This master list constitute[d] a primitive outline or classification system reflecting the recurring regularities or patterns" (Merriam, 2009, p. 180) in my data.

\section{Analyzing Artwork}

As part of analyzing the students' artwork, I used Albers' (2007) approach to reading visual representations. Albers distinguished between three basic visual text structures: aesthetic, metaphoric, and narrative. According to Albers, aesthetic visual texts are those that serve a decorative purpose; students choose to create them to make their writing pieces look pretty. The second type, metaphoric texts, are visual representations of the students' interpretation of the text, expressed through metaphor. The third category, narrative texts, are organized in the manner of a story (p. 136) and are divided into schematic texts, descriptive texts, and multiphasic texts. Each narrative text serves a different 
purpose. Schematic texts are used to show explicit and implicit relationships between objects and descriptive narrative texts depict events almost identical to the events described in the story. Multiphasic texts are created in several phases, with collage being "the most common multiphasic text found in ELA classes ... they contain many individual elements (picture texts) that overlap, collide, or merge together to tell a story" (Albers, 2007, p. 138).

My first step in analyzing the students' collages was to determine the type of visual text structure: Was it aesthetic, narrative, or metaphoric? If the text structure was narrative, I looked at how the story was organized. Next, I looked at the visual texts' orientation by dividing each collage into four quadrants. According to Albers (2007), most texts are oriented either from left to right (horizontal orientation) or from top to bottom (vertical orientation). In the horizontally oriented texts, the information that represents what is known or has been established (reality) is displayed on the left side, while the new information (ideal) is displayed on the right side. In the vertically oriented texts, the ideal is represented in the top two quadrants and reality is displayed in the bottom two.

After I established orientation, I looked at colors, lines, shapes, and compositions. I wanted to know: Were the students using warm or cool colors to show the mood of the text? Were they using angular or curved lines? What shapes were present in the artwork and how were the images arranged? (See Appendix C.) 


\section{Collapsing Codes}

After I finished coding my entire set of data with a pencil, I typed up all my preliminary codes. Afterwards, I used the list of codes and different colored sticky notes to arrange the codes into groups. Once I established the groupings, I transferred my data into a table. Initially, I generated a large number of categories across various sets of data. However, I only kept those that "seem[ed] to hold across more than one interview and set of filed notes" (Merriam, 2009, p. 182). By doing this, I gradually reduced the number of categories and combined them into seven themes, which I used to write my narrative (see Appendix D).

\section{Data Organization}

As the study progressed, I created a separate electronic file for each study participant. I retyped students' written reflections. I also created a binder for hard copies of all data and organized it by (a) final narratives, (b) collages, (c) reflections, (d) initial interviews with students, (e) initial interview with the ESL

teacher, (f) final interviews with the students, (g) final interview with the ESL teacher, (h) memos, and (i) emerging codes and themes.

\section{Credibility and Trustworthiness}

To increase the credibility and trustworthiness of my study, I used triangulation, peer review, researcher's position, member checking, and thick descriptions.

- Triangulation: I depended on a variety of methods for obtaining data, including informal and semi-structured interviews; field notes; analytic 
memos; and student work, including drafts and final writing pieces, reflections, and collages.

- Peer Review: I sought out the input on my work from my professors and fellow PhD students "regarding the process of the study, the congruency of emerging findings with the raw data, and tentative interpretations" (Merriam, 2009, p. 229).

- Researcher's Position: I addressed researcher bias by reflecting on my own assumptions and exploring my own biases.

- Member Checking or Respondent Validation (Merriam, 2009): I shared interview transcripts and analytical thoughts with the participants of the study to make sure their words were represented accurately (Creswell, 2013). As Maxwell (2005) argued:

This is the single most important way of ruling out the possibility of misinterpreting the meaning of what participants say and do and the perspective they have on what is going on, as well as being an important way of identifying [the researcher's] own biases and misunderstanding of what [the researcher] observed. (p. 111)

- Thick Descriptions: I used thick/rich descriptions "of the setting and participants of the study, as well as a detailed description of the findings with adequate evidence presented in the form of quotes from participant interviews, field notes, and documents" (Merriam, 2009, p. 227 ) in order to provide a vivid picture of the research study.

\section{Summary}

Lanier Middle School had a population of approximately 900 students, who spoke a total of seventeen languages. Students received ESL services if 
they were classified as Limited English Proficient (LEP) by the Program Services Plan (PSP) committee. The committee also ensured a personalized plan per student, which resulted in a variety of plans per classroom, as exemplified in the diverse classroom used for this study.

Ms. D's eighth-grade ESL students varied greatly in their level of English proficiency. Seven participants were male; six were female; the majority of the students (eight) spoke Spanish. According to Ms. D, her students struggled with narrative writing and many believed that their writing needed improvement. This struggle with language provided an opportune situation for Ms. D to implement a multimodal unit and allowed me to do this study.

I conducted student and teacher interviews and collected and analyzed data, field notes, pictures, and student work samples. For my overall analysis, I used control-value theory and Pekrun's (2014) four types of academic emotions: student achievement, epistemic, topic, and social. For the collages, I analyzed the students' choice of orientation, colors, lines, shapes, and compositions, using Albers' (2007) approach to reading visual representations.

In the next chapter, I will discuss my findings. Specifically, I will focus on achievement emotions related to writing and collage making. I will also discuss the role of emotions in students' collages and narratives. 


\section{CHAPTER V: FINDINGS}

\section{Alberto and Olga's Stories}

When Alberto entered the classroom, he pulled a chair closer to the teacher's desk where I was sitting and placed his collage and narrative in front of me. He didn't say a word; he just patiently waited for the interview to begin. He wasn't looking at me. His brown eyes were focused on the collage (see Figure $5.1)$.

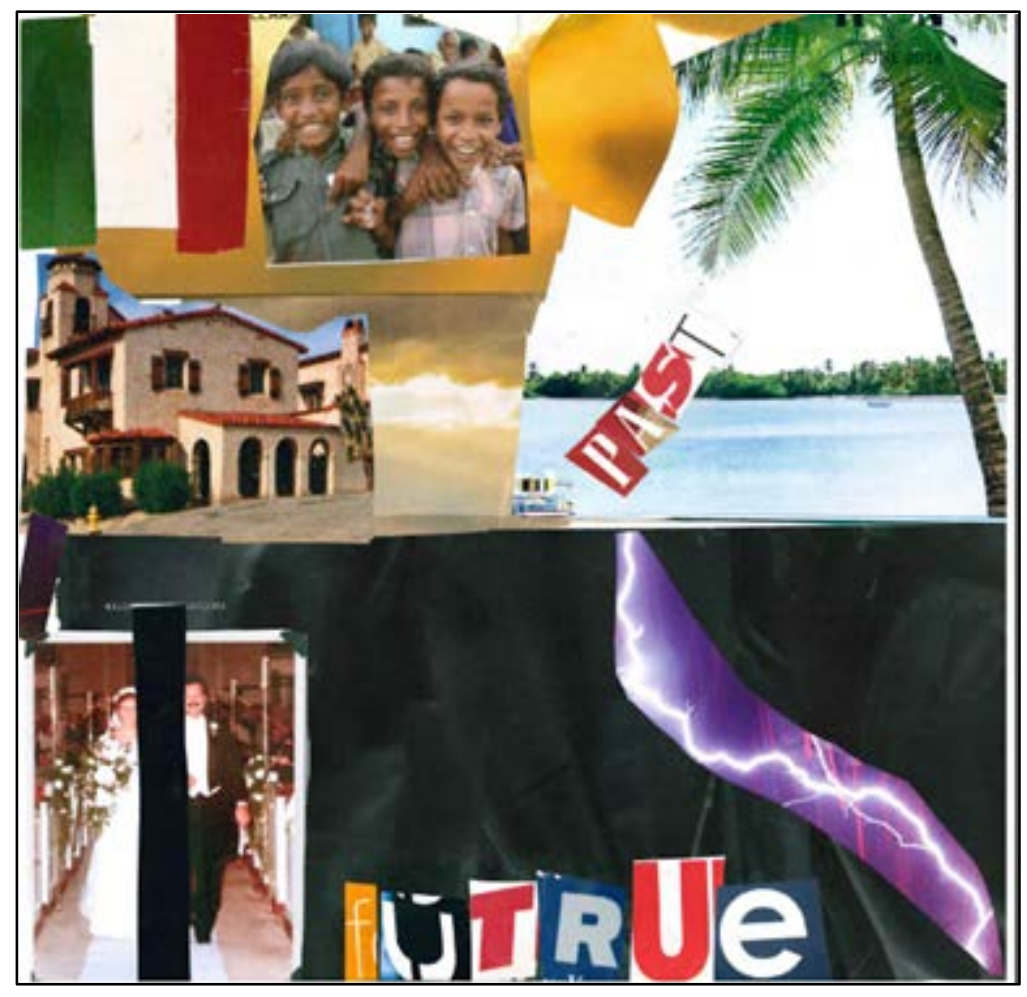

Figure 5.1. Alberto's collage, representing his parent's separation.

"How are you?" I smiled, "Did you have a good day?"

He nodded but did not say a word. "So what good things happened 
today?" I probed. He shrugged his shoulders and once again did not say word. I wondered if getting Alberto open up would be a challenge. I remembered how difficult it was to get him to talk during our initial interview. I also remembered that the only person he communicated with in class was Manuel, his elbow partner. And the only time he talked to him was when the teacher instructed the students to share their thoughts with someone who was sitting next to them. Alberto was looking at his collage so I decided that asking him about that might help him feel comfortable.

"Let's talk about the unit that you just finished... what was your experience with writing and collages? Can you tell me about it?" I asked in a friendly tone of voice. Alberto did not respond but he seemed to be thinking.

"Writing is a waste of time," he finally said. He continued:

Collage seems great. It seems fun. It's just good for to remember in the past. It was the most helpful. I would go for collage. You can cut out some stuff and put it on paper, get some background, get some ideas for what you're going to do. And I have a lot of great ideas but the writing is just like I don't have great ideas. If I had to choose between writing and collage, I would choose this one [pointing at the collage].

"Tell me about your collage," I asked, moving the collage closer to Alberto.

All right. Well, about this story, it was just in the past, it was all wonderful. That is why I put the palm tree and sun, and I have three brothers (that ain't me though in the picture). Yeah, we bought like a house or something like that but I was born in here. I just put the Mexican flag because I know my both parents were from Mexico but brothers are from here as well. But in the future it's just like they got married and then they broke up because they got in a fight in a bad situation right now. It makes me sad. It makes me want to go to the back and forget about the future.

"How old were you?" 
About seven or six years old. I wish I could go back here," Alberto pointed to the upper two quadrants of the collage. "When I remember those memories, it makes me want to cry.

I looked at Alberto. His eyes were still on the collage. I noticed that they were red. "Did you share your feelings with anyone?" I asked.

"No, I just wanted to be alone with my collage," he lifted his head up and looked at the ceiling. I figured he was doing it to prevent tears from rolling down his cheeks. "How did working on the collage make you feel?" I asked.

It brought back memories but it doesn't make you feel any better-just in the middle. But I needed to talk about what happened and why they move on. I needed to remember in the past and how it affected us because you see, life will never be happy again.

This time he looked at me. His eyes were wet but he didn't reach for the tissue box sitting on the desk. I thanked Alberto for the interview; after he left, I studied the collage. It was vertically oriented; the story was told from top to bottom. Alberto showed his past in the top two quadrants of the collage and depicted his present in the bottom two. He used warm colors to describe the past, the world that he wanted to go back to, and dark colors to show the present. A black background dominated the bottom quadrants. Alberto used images from magazines and one wedding photo of his parents to tell the story. He cut out and glued a thick black strip of paper in the middle of the photo to show the parents' separation. As I was carefully examining the colors, lines, and images in Alberto's collage, I kept thinking about the sadness in his voice as he shared this emotional event and the tears in his eyes as he talked about his collage. Then I read his narrative, "Relationship": 
How could a relationship have gone so wrong so quickly? I thought to myself as I placed boxes of my clothes and books into back seat of my dad's old Honda Civic. After my family are done packing our stuff up, we got into the car, we gave me dad hugs and kisses and said our goodbyes and I love you. My mom put the car on drive and pulled over slowly to talk to my dad.

"Can we talk about this?" My dad said with pain in his voice.

"No," my mom responded.

"Why?" [Dad]

"Because I'm tired of all of this fighting, the problems, and arguments we have to every single day and night." [Mom]

"Please I need you, I can't survive without you." [Dad]

"I'm sorry but it's too late now goodbye Ismael." [Mom]

It was crazy how fast she seemed to move on nut two days later, my mom had already found a new place to live. The house was great and it wasn't that bad but it's not call home if my dad want here. This morning my mom told to come to the living room with my brothers then I said ok mom. When we go to the living room with my brothers she told us "don't be like your father because he is stupid and lazy". And if he calls you don't answer, don't pick up, and don't respond too. "OK?" my mom said to me and brothers.

"Ok mom," me and my brothers respond.

Later that day, somebody is calling in my phone it has no name only it was the phone number that's all. I didn't know what to do. I was thinking should I give it to my mom, pick up the phone or should I hang up. I wanted to pick up to ask him that what happen to you and mom, why did the both of you break up but I promise my mom that I will never pick up so after all that thinking I decided to hang up the phone.

After I finished reading, I sat in silence for a few moments and then I re-

read it. Something was missing and I couldn't quite figure out what it was. I

finally realized that Alberto had not used a single word to describe his emotional state and the feelings that were evoked by his parents' separation-one of the 
most dramatic events in his life. It was his collage and our conversation that revealed Alberto's emotions. Just as I was done reading, I noticed Olga. She patiently waited for me in in the hallway. I set aside Alberto's work and invited her in. Olga's straight brown hair was pulled in a tight ponytail. She used two small snap hair clips to keep her bangs away from her round face. Olga smiled as she entered the room and sat in the chair in front of me. I asked her if she didn't mind me tape-recording our conversation and she nodded in agreement. I placed the recorder on the corner of the desk, so it would not distract her and proceeded with my questions. Similar to Alberto's interview, I was interested in her experience with collage-making and writing and her feelings towards both activities. I was also interested in what Olga learned about herself and the communicative modes she used to tell her story. When I asked her about writing, Olga responded:

It's not hard if I pick the right topic. Once I get into the writing, I know what I am doing. I can express more through writing. We did a lot of learning about writing in class. Learning about writing helped to get ready for high school. I like writing.

"What topics are difficult for you and which ones are easy?" I asked.

"The ones I like is personal narratives. The ones that are about you. The ones I don't like are short stories."

"What is your preferred mode of communication, if you have one?" I asked.

"If it's about telling a story, I prefer writing. I can explain more in writing." "What about collage? How do you feel about it?" I asked. 
"It helped to express feelings. It helped remember the past. I feel good about collage. It just takes it out of me," Olga paused. She was thinking and I did not want to interrupt. A few minutes passed before she continued:

This collage is about my life and how I feel. Well, I have two sides because there's good and wrong. I was bullied in Russia and this is a small picture of her. She doesn't look like a bully but she was very mean. I put her in the middle because she could have chosen the right side, but since she didn't choose the right side, she just started to be mean and everything. And the word "'hope"'" means everyone can change but it just depends if that person wants to change or not. The Russian flag because it happened in Russia and then the building above 'hope' that's just to show it was Russia. Yeah, I'm right there on the not so happy side trying to forget those memories but I can't. Grey shows how sad and upset I am still.

Tears rolled down Olga's cheeks, and she wiped them off with the sleeve of her maroon uniform shirt.

"I try to forget it but it's so hard," she finally said.

Before I could say anything, Olga added, "Collage helped me as far as how I felt. I felt good inside that I can express feelings. I just don't like sharing it to many people that I got bullied when I was in Russia. It makes me sad."

I looked at Olga's collage (see Figure 5.2). Just as she said, it had two sides with a small picture of the girl who bullied Olga in the orphanage in the middle. The background on both sides was grey, which explained Olga's past and present emotions. She glued the words "two sides" in the middle of the collage. Olga mentioned in her interview that there are "two sides because there's good and wrong" and that the bully could have chosen the "good" side but she didn't. 


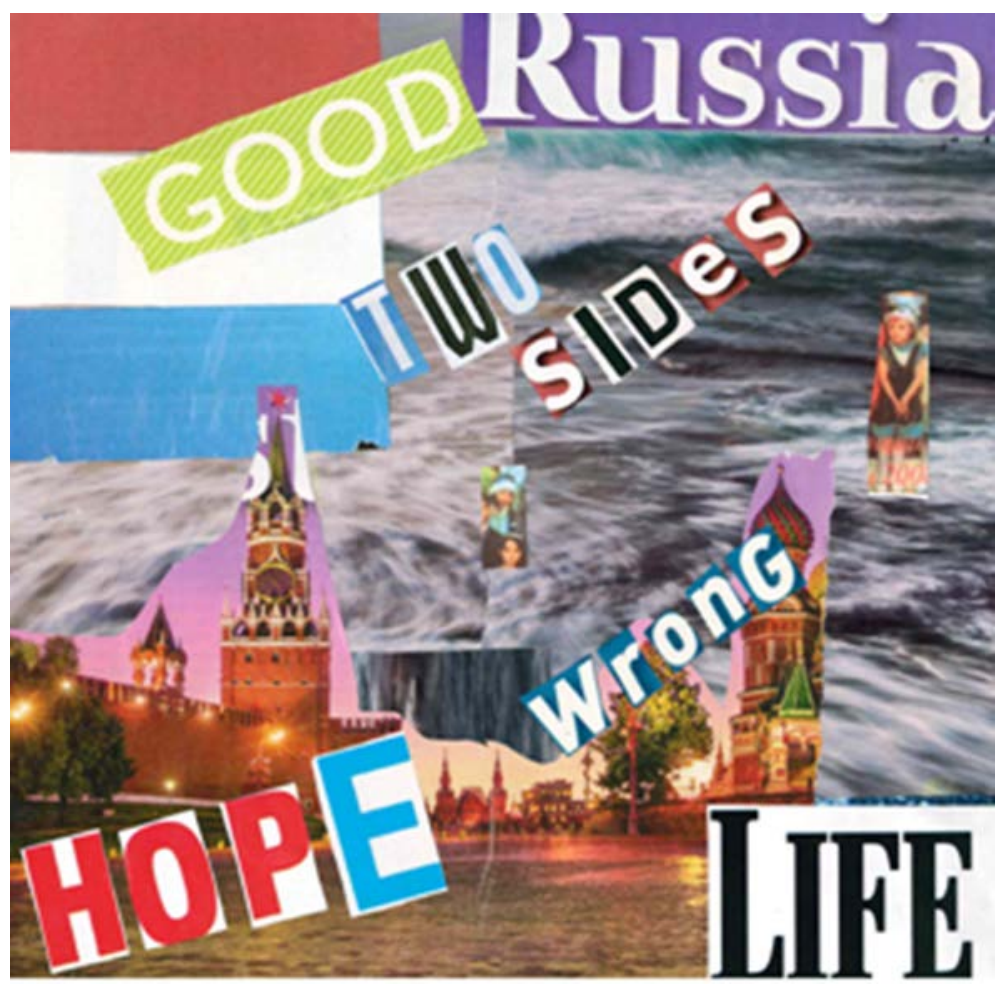

Figure 5.2. Olga's collage, representing her life in Russia.

Olga's collage made me think of her life. She spent exactly half of her life in an orphanage in Russia and half in the United States after she was adopted by a caring and loving couple from Kentucky. Her life in Russia was hard and filled with sadness. Olga's life in the United States was filled with love, but her memories of the past were clouding her present. She placed a photo of herself on the "wrong" side of the collage above the word "Life" as if to say that it was wrong that the memories of the past still tormented her. Her life in the United States should have been joyful, instead, it was sad. The word 'hope' in the bottom left quadrant of the collage could possibly represent not only Olga's wish for the bully to change but also for her own life to change as well. In our conversation, she told me how much she had hoped that someone would adopt her. Several people visited the orphanage and even talked to her but then they 
picked other kids and not her. Every time she would get excited about a family adopting her, her hopes were crushed and she felt rejected, hopeless, and heartbroken. Olga almost gave up her dream when, one day she was invited into the headmistress's office to meet a couple from Kentucky. In her final interview, she shared with me:

I was afraid that these people will reject me too. I was nervous to answer their questions because I was afraid they will not like me. But they came back next day and we talked more. Then they came back again and we talked again. They asked me if I would like to move to the United States with them. It was the best day in my life.

After the interview was over, I read Olga's narrative. She used one sentence to describe her emotions, "Well I was happy but I was furious that she didn't get in bigger trouble than that."

Alberto and Olga's experiences were vastly different and happened hundreds of miles apart. Alberto wrote about his parents' separation and Olga described her life in a Russian orphanage and the bullying that she had endured daily. Both students chose two different orientations for their collages as wellAlberto's collage had a vertical orientation while Olga's collage had a horizontal one. The only commonality between the two was that the students used collage to reveal deep emotions that affected their current reality. Neither of them wanted to share their emotions openly with the class but both expressed an appreciation for the opportunity to reveal how they felt. The students employed two communicative modes, collage and written language, to tell their stories. Written language allowed them to describe events in their lives and collage helped to reveal emotions. Both modes complemented each other and allowed the students to describe an experience that impacted their lives and who they 
had become as individuals. Multimodality offered English language learners two ways to reveal their life stories and identities.

In class, the students had learned that, in the vertically oriented collages, the top two quadrants represented the ideal and the bottom two represented reality (Kress \& van Leeuwen, 1996). They also learned that, in horizontally oriented collages, the left side quadrants represented things that were known, while the right side quadrants represented new information (Albers, 2007). When working on their collages, the ELLs had to decide which orientation to choose: vertical or horizontal. They had to think about their experiences and differentiate between what was "real" and what was "ideal". Collage-making required the students to do deep analytical thinking—students had to look at the experience and separate it into meaningful parts then analyze the relationship between these parts and their role in the relationship. Collage-making also required students to employ their creative thinking-ELLs used colors, images, lines, and shapes to communicate with the audience and reveal parts of themselves that were hidden from others and possibly even themselves.

\section{Emotions in Students' Narratives}

As I continued reading English language learners' personal narratives, I realized that even though their stories differed, they had some commonalities. Two students (Alberto and Maria) described their parents' separations; three (Vivian, Marco, and Isabel) shared tragic events of losing loved ones; four students (Yoselin, Fatima, George, and Manuel) focused on their moves to the United States; two (Olga and Ernesto) addressed bullying; and two (Amal and 
Chol) dealt with accidents that affected their well-being. These events changed the trajectory of the students' lives and had an impact on their identity development (see Table 5.1).

Table 5.1

Student Narratives: Topics and Descriptions

Student Topic Description

Alberto Family Alberto's parents divorced when he was young. He Separation says these are his only happy memories and he wants to forget about his future.

Maria Family Her happy home and carefree life became nothing but Separation memories from the past when Maria's parents decided to separate. Having to go back and forth between her mom and dad made life stressful and complicated.

Vivian Losing a A typical weekend turned into the darkest day in Loved Vivian's life when she saw her mother lying dead on One the ground after touching an electric wire during a thunderstorm.

Marco Losing a A secret that was kept in his family for years was finally Loved revealed after Marco overheard his mother talk on the One phone with a friend. Marco and his twin brother had a baby sister who died soon after she was born. The news changed a lot of things in life for Marco.

Isabel Losing a It is never easy to lose someone particularly when it Loved happens unexpectedly. When you come home from One school after having a good day, you expect happiness to continue, instead, you learn that your step grandfather died of a heart attack and your mother takes it so close to heart that she gets seriously ill. 

Yoselin Moving to Yoselin and her mother moved to the United States in the U.S. hopes of having a better life. Leaving the comfort of home and dealing with the unknown put a lot of pressure on Yoselin and made her transition to a new life painful and stressful.

Fatima Moving to Fatima was raised by her grandmother. When Fatima's the U.S. mother called and said that it was time for them to reunite in the United States, Fatima wasn't ready. On top of everything, she didn't get to say a proper goodbye to her grandmother at the airport.

George Moving to George spent most of his life with his grandmother in the U.S. Mexico. Moving to the United States to join his parents wasn't easy for him. He knew that neither his grandmother nor his friends would be able to come with him.

Manuel Moving to Manuel learned about his family's decision to relocate the U.S. $\quad$ to the United States the night before the move. His parents didn't want to leave him behind in Mexico so he had to say goodbye to everyone he knew and loved. Luckily for Manuel, his story had a happy ending - his parents were able to save enough money to bring the rest of the family to the U. S.

Olga Bullying Life in a Russian orphanage was darkened by constant emotional and physical bullying that Olga endured daily. No matter how hard she tried to forget her childhood years, the memories of the past continue to haunt her.

Ernesto Bullying What do you do when the immigration service officers knock on your door in the middle of the night and demand to search your house without a warrant? What do you say when they take your father away without a probable cause? Will you see him again? Will your life be the same again? 
Amal Accident One of the best days in Amal's life turned into a disaster when his friend pushed him off a cliff and Amal broke his arm in several places. He was in need of a surgery but no one in his hometown would agree to do it. The injury caused him to miss many days of school and fall behind in his studies. Only when the family moved to the United States was he able to receive the proper medical treatment and gain full control of his arm.

Chol Accident Chol and his parents had everything they had hoped for until the day their house burned down. In a matter of minutes, they lost all of their possessions and were left only with memories of what life used to be before the tragic fire.

I read each narrative twice—during my first read, I focused on the overall content of the story; during the second read I paid attention to the students' choice of words, focusing on the words and phrases they used to describe their emotions and the feelings that the events evoked. None of the students elaborated on their emotional states. Rather, the emphasis of each piece of writing was on the sequence of events that led to a dramatic event and the event itself. Three out of thirteen students did not describe their feelings at all; five students used one word only to depict their emotions, with one student using the same word twice in the narrative; and four students incorporated between two to three words to reveal how they felt (see Table 5.2). 
Table 5.2

Student Emotion in Narrative

Student Event Emotion Expression

Alberto Family Separation None

Maria Family Separation Everything was weird, strange, and sad.

Vivian Losing a Loved One I am longing to see her face now.

Marco Losing a Loved One I was sad of what my mom had told me.

Isabel Losing a Loved One None

Yoselin Moving to the U.S. I remember that day I was so sad because I was going to leave all my family and I knew that I would never see them again. We all cried, I never been so sad.

Fatima Moving to the U.S. I was excited because I haven't seen my mom since I was 3 years old.

George Moving to the U.S. I was frightened because I was going to be with my sister only and not with my grandmother...

Manuel Moving to the U.S. I was mad so I ran... The whole trip I was sad...

I was so happy, I jumped up with excitement and I hugged my parents...

Olga Bullying Well I was happy but I was furious that she didn't get in bigger trouble than that.

I got so worried and scared.

Ernesto Bullying

I was scared because it was my first time

Amal Accident doing surgery.

Chol Accident 
Ms. D joined me during her planning period. She printed the ELLs' final narratives so that she could write comments for them. The published piece was the students' summative assessment. The goal of a summative assessment is to evaluate student learning at the end of the instructional unit by comparing their narrative writing against a benchmark. Therefore, Ms. D created a rubric which included the following categories: engaging title, lead, explode the moment, dialogue, plot, engaging conclusion, varied sentences and transitions, and colorful language_-everything she had taught them during the mini-lessons throughout the unit (see Figure 5.3). As I was reading and taking notes on how the ELLs expressed emotions, Ms. D was assigning points for each category and writing notes on the rubric explaining what students did well to get the full value points for a specific category and why she took some points off. Since I started reading personal narratives before Ms. D could join me, I completed my analysis ahead of her. I waited for Ms. D to finish grading before I shared my findings. 
Personal Narrative

\begin{tabular}{|l|c|l|l|}
\hline \multicolumn{1}{|c|}{ Include } & Point Value & Point Scored & Notes \\
\hline Engaging Title & 5 & & \\
\hline Engaging Lead & 15 & & \\
\hline Explode the Moment & 20 & & \\
\hline $\begin{array}{l}\text { Dialogue (correctly } \\
\text { punctuated) }\end{array}$ & 10 & & \\
\hline $\begin{array}{l}\text { Plot (conflict, turning point, } \\
\text { resolution) }\end{array}$ & 20 & & \\
\hline $\begin{array}{l}\text { Engaging Conclusion } \\
\text { Score }\end{array}$ & 15 & & \\
\hline $\begin{array}{l}\text { Varied Sentences and } \\
\text { Transitions }\end{array}$ & 5 & & \\
\hline $\begin{array}{l}\text { Colorful Language } \\
\text { strong verbs) }\end{array}$ & 10 & & \\
\hline & 50 & & \\
\hline
\end{tabular}

Figure 5.3. Ms. D’s writing rubric.

Ms. D was genuinely surprised and pointed out that she explicitly taught the importance of emotions in literature to English language learners. Every time she introduced her students to a picture book or a story during the unit, she made sure they discussed how the main character felt and how the words and actions of the characters made the audience feel. In order to help her students 
describe their personal experiences, Ms. D distributed several copies of the Explode the Moment graphic organizer she had found on the ReadWriteThink.org website. The purpose of the graphic organizer was to center ELLs' attention on what the character in a story says, thinks, feels, does, hears, and sees. Ms. D modeled how to complete the graphic organizers when reading aloud Let's Go See Papa (Schimel, 2011). Students filled out the graphic organizer with a partner when they read and discussed The Day I Followed written by Eric Luper and published in Dear Bully: 70 Authors Tell Their Stories (Kelley Hall \& Jones, 2011). Finally, they worked on completing the graphic organizer independently when drafting their personal narratives. The students were encouraged to write in complete sentences, yet many chose to put down only one or two words next to the icon of a heart and the word 'feel' below it. This was consistent with the students' final narratives. English learners either did not describe their emotions or kept their description to a minimum. In contrast, most of the students did well re-counting specific details, thoughts, and conversations. Their sentences varied in length and linguistic complexity and paragraphs included detail.

\section{Emotions in Students' Collages}

In order to have a better understanding of the English language Learners' collages I asked them to describe their artwork. During the final interviews, the students told me about their collages and what certain colors and images meant to them. I tape-recorded their explanations and then transcribed them. I later 
combined the students' collages with the transcriptions of the interviews pertaining to the collages in the table below (see Table 5.3).

Table 5.3

Students' Explanation of Their Collages

$\underline{\text { Name }}$

Alberto

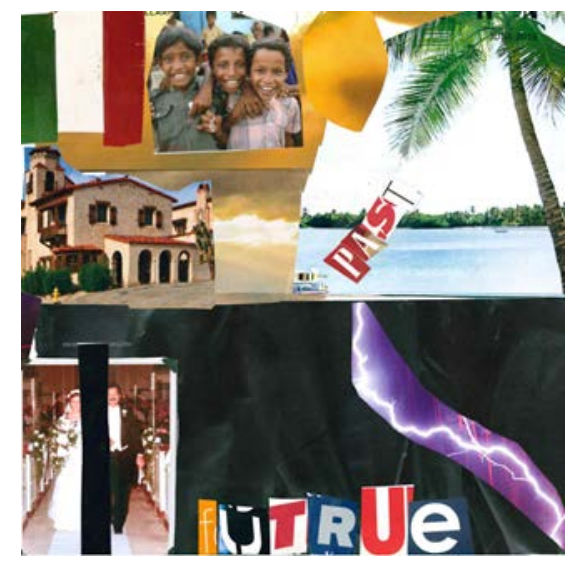

\section{Student Explanation}

All right. Well, about this story, it was just in the past, it was all wonderful. That is why I put the palm tree and sun, and I have three brothers (that ain't me though in the picture). Yeah, we bought like a house or something like that but I was born in here. I just put the Mexican flag because I know my both parents were from Mexico but brothers are from here as well. But in the future it's just like they got married and then they broke up because they got in a fight in a bad situation right now. It makes me sad. It makes me want to go to the back and forget about the future. [I was] about seven or six years old. I wish I could go back here [pointing to the upper two quadrants of the collage]. When I remember those memories, it makes me want to cry. 
Maria

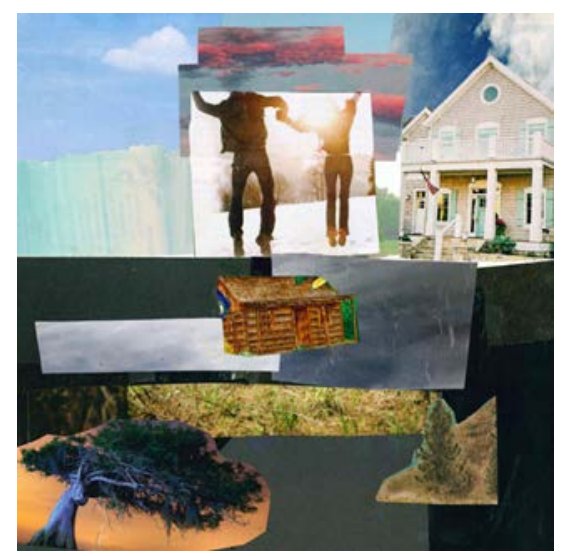

Vivian

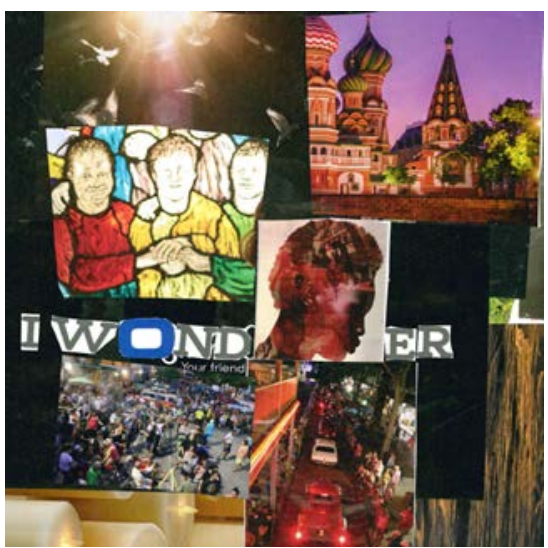

It [collage] talks about how my mom was happy and dad and then on the bottom I tried to make it sad like the trees were dry. That's supposed to be my house and I liked it even though it is brown [referring to brown color representing sadness]. It's in the middle because it was how our house used to be. It was brown and all happy and big part of us, then they separated and it all just stopped. The tree is not green because I am not happy. And dark. I wanted it that way because my real is dark and not happy.

My story is the day I will never forget. The day when I lost my mom. Right here [bottom left quadrant] it's me showing what happened. When I saw her on the ground and here [top two quadrants] are where all the things I was thinking. This represents when she was being taken away to the hospital [bottom right quadrant] and all those people who are standing around me. I used a picture of saints and doves for my mother's transition to the eternal life. My life here in America is this picture. It is beautiful building. I put me in the middle. We lived in Congo and if my mom did not dies we would have stayed there. I love America but I ask did the spirits take my mother so I can have a better life? Is my future better when my mother is not here? What would happened to me if mother was with me? What kinda life would I had if mother was with me? You see I have many questions and I have words "I wonder". 
Marco

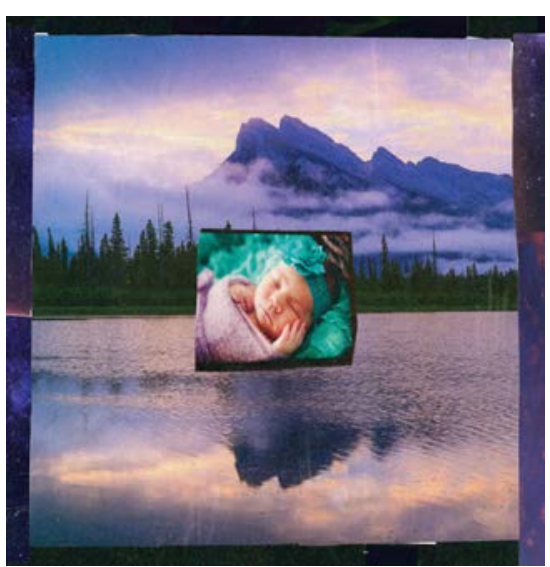

Isabel

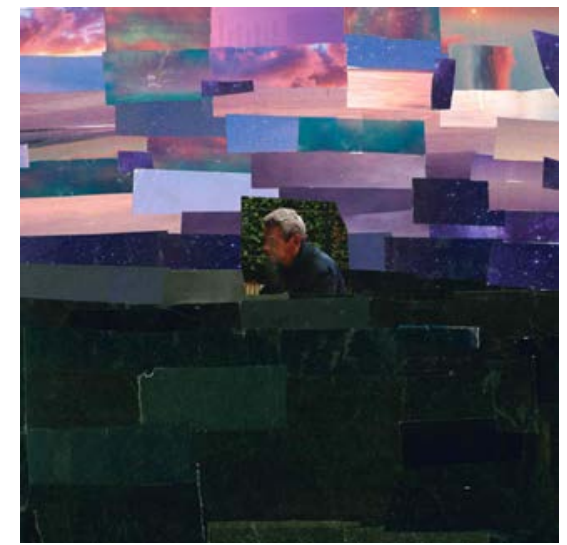

Well, it's about my mother and sister when she died in three days after she was born. Yeah, she was born in Mexico and sick from her kidney. She was so little. It makes me sad that she died. Water represents life but the border represents death... the dark colors. But everything in the picture represents life. So the baby is still alive in my heart. When I was doing collage, I was thinking like why did she die and why can't she be alive right now? And what would life be like if she was alive?

It was the saddest day. I came home and my mom told me that my step dad had a heart attack. I was happy that day but it all changed when I got home and my mom got sick after that too. I put a picture of my step dad in the middle. It is not him. I just found a picture to look like him. The colors show how I feel. And I thought a lot about him dying and how different our lives are without him and how sick my mother got because of him dying. You see my mom's real dad was abusive and my mom hated him with all her soul. And my step dad was good to us and took care of us and he will always be in our heart. 
Yoselin
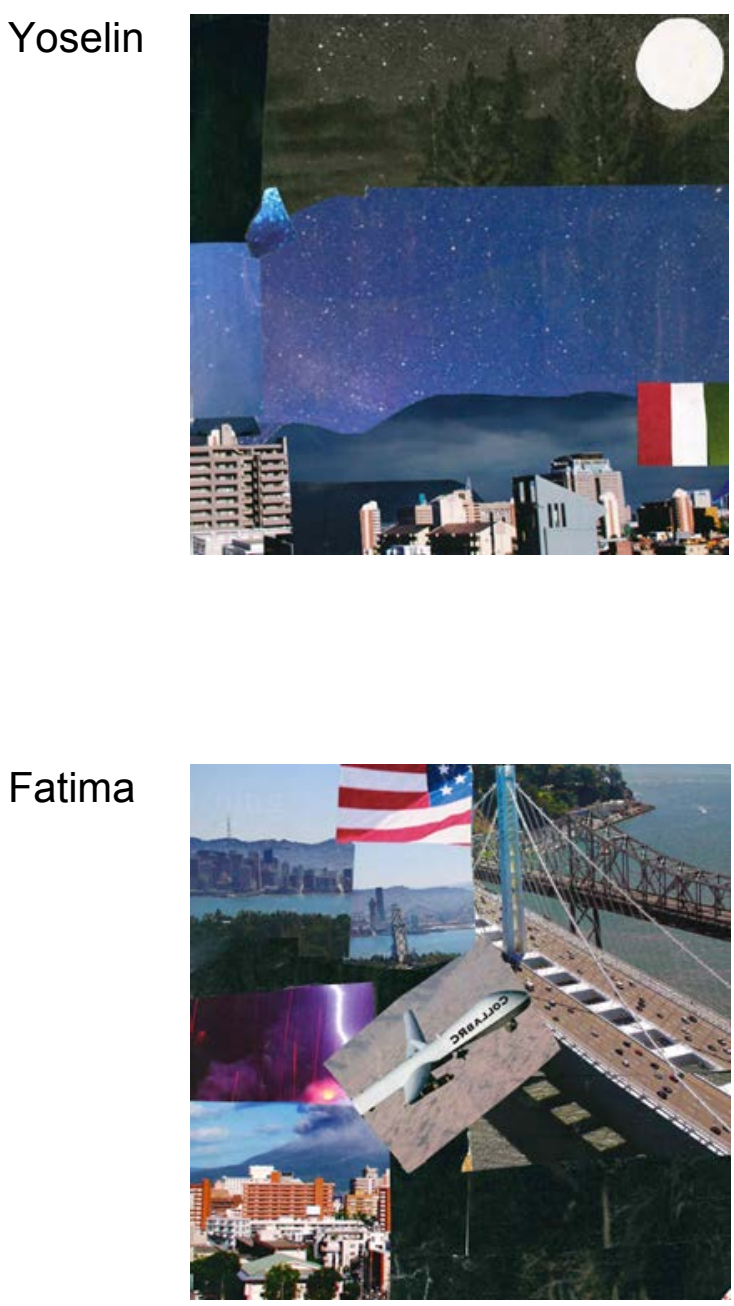

This collage is when I came to the United States. This Mexico [bottom two quadrants]. And this collage is my last day in Mexico. And then I used blue to make it sad. And black. I came here with my mom. She just said let's go one day and we go. It was a sad, sad day. I miss my family and dad and home. I want to go back.

Here is where I grew up in Somalia. Mom was here in the US. Yeah she was here. She came before me when I was three. So when I was little I had to leave home to join her. I was eight. I lived with grandmother. So she had business and stuff. So she couldn't move. She couldn't go with me. So I travel and then I came here to live with her. The plane shows how I got here. My grandmother is still there and I miss her. I was happy to see mom but sad to leave my grandmother. The happy times in this collage are right here, in this corner that represents my childhood with grandmother. Even though I traveled to America to see mom, this is still the only happy corner, my life with grandmother. 


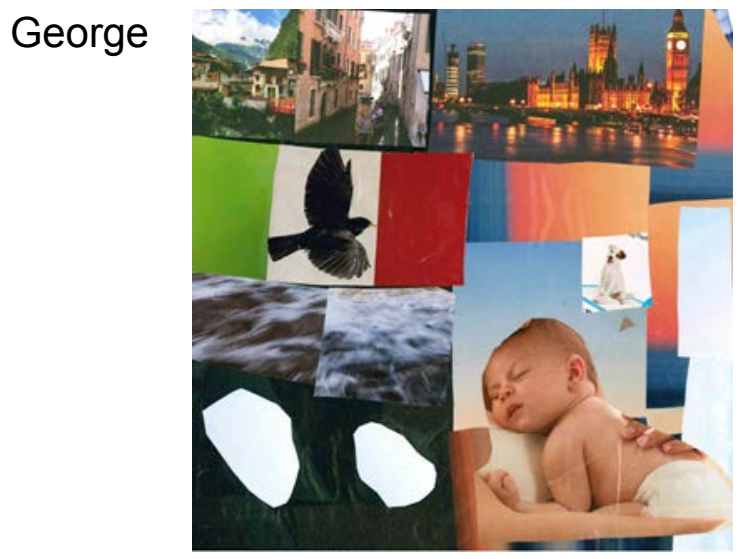

Manuel

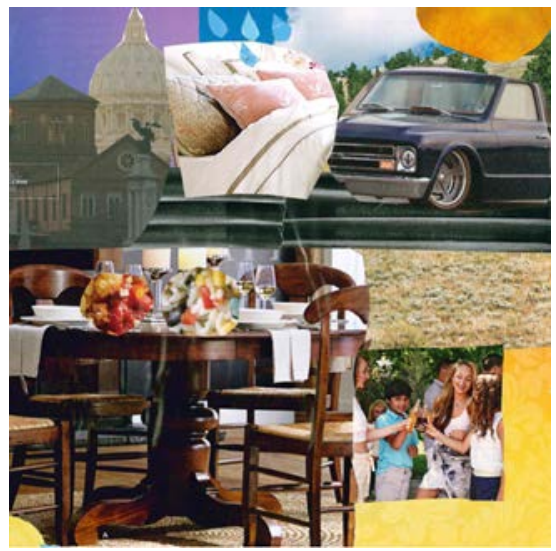

I just wanted to describe how I felt. This whole thing [upper quadrants of the collage] it was like happy moments and sad moments when I miss my parents when they were right here in the United States. Also, dark clouds represent my feelings [left bottom quadrant]. Two white spots are happy moments. I didn't have that much happy moments there so I just put two white clouds. I put baby because my mom got pregnant and had a baby and that's happy because I have a brother. Oh, I got a dog too here. His name is Toby.

First it started off in a deserty place. It was dry and really nasty - a nasty feeling. And then after that...oh, when my mom told me that we were going to leave to the United States, I ran to my room and ended up falling asleep because of how sad I was. Collage, the top part shows how I felt because I didn't want to leave where we lived and that is why I have a sad night and cold rain and the car explains how the long trip to America was. We got in a car and drove for a long time. And I was sad the entire time. And then we lived here and after that the whole family came together with my grandma because she came to visit and we all had a reunion and we ate and had fun. That's why the family is there. 
Olga

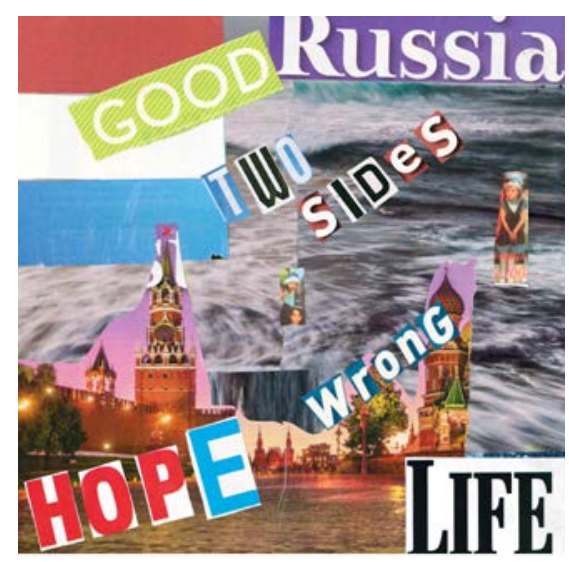

Ernesto

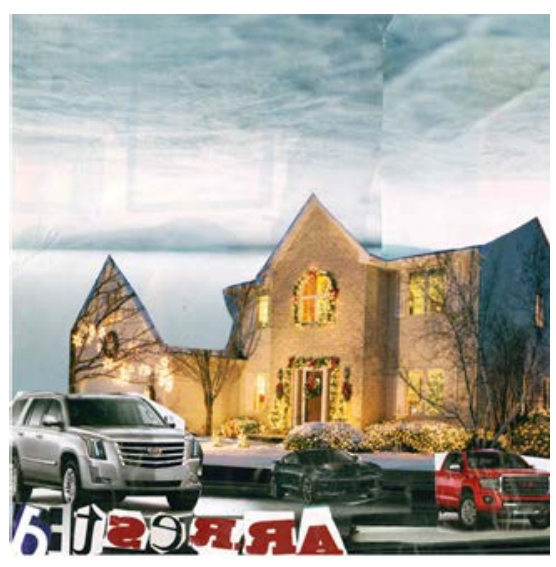

This collage is about my life and how I feel. Well, I have two sides because there's good and wrong. I was bullied in Russia and this is a small picture of her. She doesn't look like a bully but she was very mean. I put her in the middle because she could have chosen the right side, but since she didn't choose the right side, she just started to be mean and everything.

And the word "'hope"' means everyone can change but it just depends if that person wants to change or not. The Russian flag because it happened in Russia and then the building above 'hope' that's just to show it was Russia. Yeah, I'm right there on the not so happy side trying to forget those memories but I can't. Grey shows how sad and upset I am still.

This is about one night when loud knocks on the door woke me up. I was scared. People kept banging on the door and when we opened it they were looking for my dad. We were confused because he did nothing. But the immigration officers took him with them. The cars in the collage remind me of the cars they drove and they parked in front of the house. Our house was happy and we were happy and that's why I put a picture of this house on my collage. But that night I was scared and sad. And the grey clouds show how I feel and that you cannot be happy all the time because sadness is above your head all the time. 
Amal

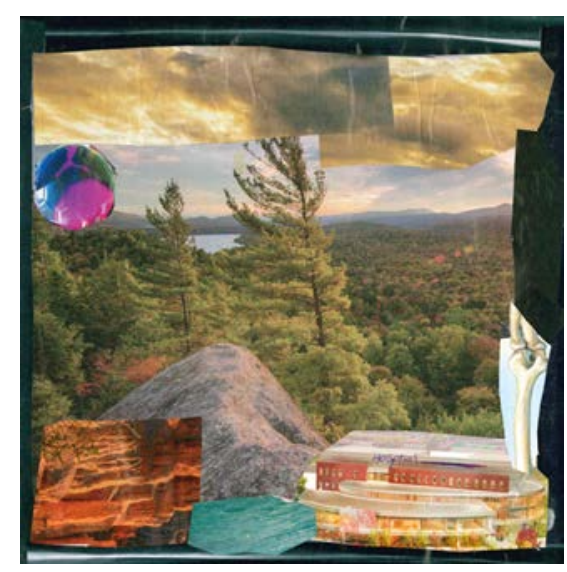

Chol

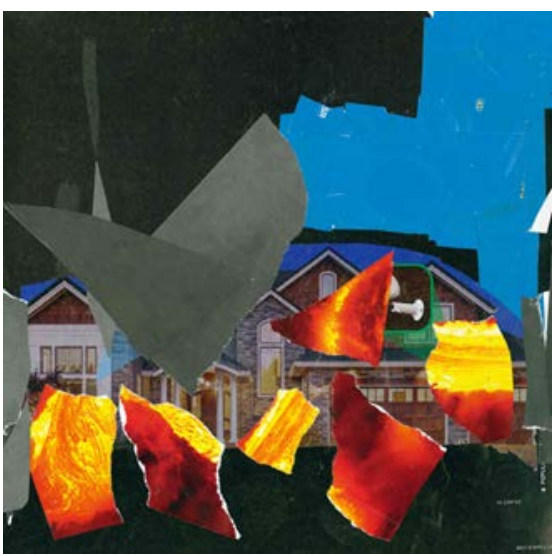

Collage is about bad things that happen in the past. Like when I was walking to my house, my friend accidentally pushed me to the rock. My bone came out of my hand. I went to the hospital but didn't stay too long. They were scared to do the surgery. So I stayed home. I didn't go to school long time. Dad took good care of me all the time. This black border represents dark things. The circle on the left represents soccer. I played soccer all that time. And I was walking to my house after I finished soccer playing. It was water there. We were swimming there after we played soccer. And we were walking through there. It was big rock there. My friend tried to scare me but he just pushed me and that's how I got hurt. They never did the surgery there. Only when I got to America they did the surgery here.

This fire was the worst day in my life. I felt sad and scared. I used blue and black colors and grey to show how scared and sad I was. The house was big and it was home. We lost it and everything. No one got hurt that is why I did not put people in the collage but we lost the house. The colors show how I feel. Oh, red and yellow represent fire. I couldn't find a picture of the fire so I had to be creative.

Ms. D's instruction on colors, lines, and shapes was detailed and included visuals to help get her point across. She taught the students that certain colors carried specific meanings and were used by the artists to depict emotions (see 
Table 5.4). Consequently, based on the events in their stories, ELLs chose different colors for their backgrounds.

\begin{tabular}{ll} 
Table 5.4 \\
What Color Meant in Students' Collages \\
Color & \multicolumn{1}{l}{ Meaning } \\
Brown & Sadness \\
Black & Hopelessness, Depression, Grief \\
Blue & Serenity, Calmness \\
Green & Balance, Harmony \\
Grey & Anguish, Unhappiness \\
Navy & Sadness \\
Purple & Spirituality, Sadness \\
Orange & Happiness \\
Violet & Contemplation \\
Yellow & Joy
\end{tabular}

Three students elected to use purple and violet—all three wrote about a loved one who died. Black, grey, and navy blue were dominant background colors in seven collages-these students wrote about family separation, moving to the United States, bullying, and accidents. Three ELLs decided to use yellow or orange as their background-these students wrote about their move to the United States and a childhood accident; however, their stories had happier endings than the stories of their peers.

The images the students used in their collages revealed that family, home, and familiar surroundings were the values they cherished the most. In his collage, George glued two pictures in the top left corner of the collage to 
represent Mexico, where he used to live with his grandmother. These were the happy moments from his past. The picture of a city in the top right corner portrayed the sadness he felt being away from his parents (see Figure 5.4). In his final interview, he said:

I just wanted to describe how I felt. This whole thing [pointing at the pictures in the upper quadrants of the collage] it was like happy moments and sad moments when I miss my parents when they were right here in the United States. Also, dark clouds represent my feelings [pointing at the left bottom quadrant]. Two white spots are happy moments. I didn't have that much happy moments there so I just put two white clouds. I put baby because my mom got pregnant and had a baby and that's happy because I have a brother. Oh, I got a dog too here. His name is Toby.

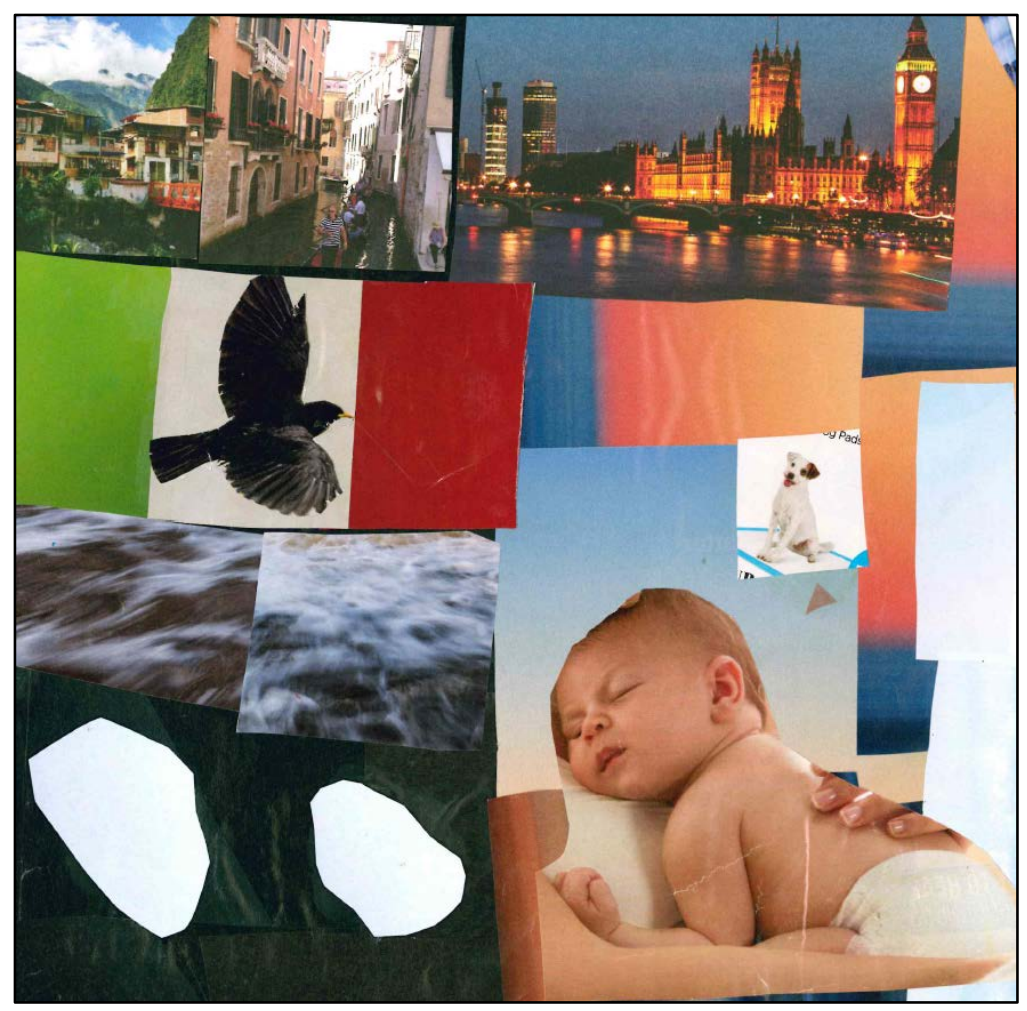

Figure 5.4. George's collage, depicting his move from Mexico to the U.S.

George was one of three students who included warm colors into the background; he also used a vertical orientation for his collage. George depicted his mixed emotions through colors. He revealed happy emotions about his 
reunion with his parents, baby brother, and dog through the orange background. He used black and grey colors to show the hopelessness, depression, and grief that he feels inside because of the losses he suffered—his grandmother had to stay in Mexico along with other family members and friends.

Manuel was the second student who used cool and warm colors to show emotions (see Figure 5.5). The background in the top two quadrants differs from the background in the bottom two. Manuel learned about the family's move to the United States the night before and was saddened by the news-his feelings are described in the top two quadrants. Once his grandparents joined the family in America, life became joyful again—Manuel used warm colors to reveal emotions and his reality.

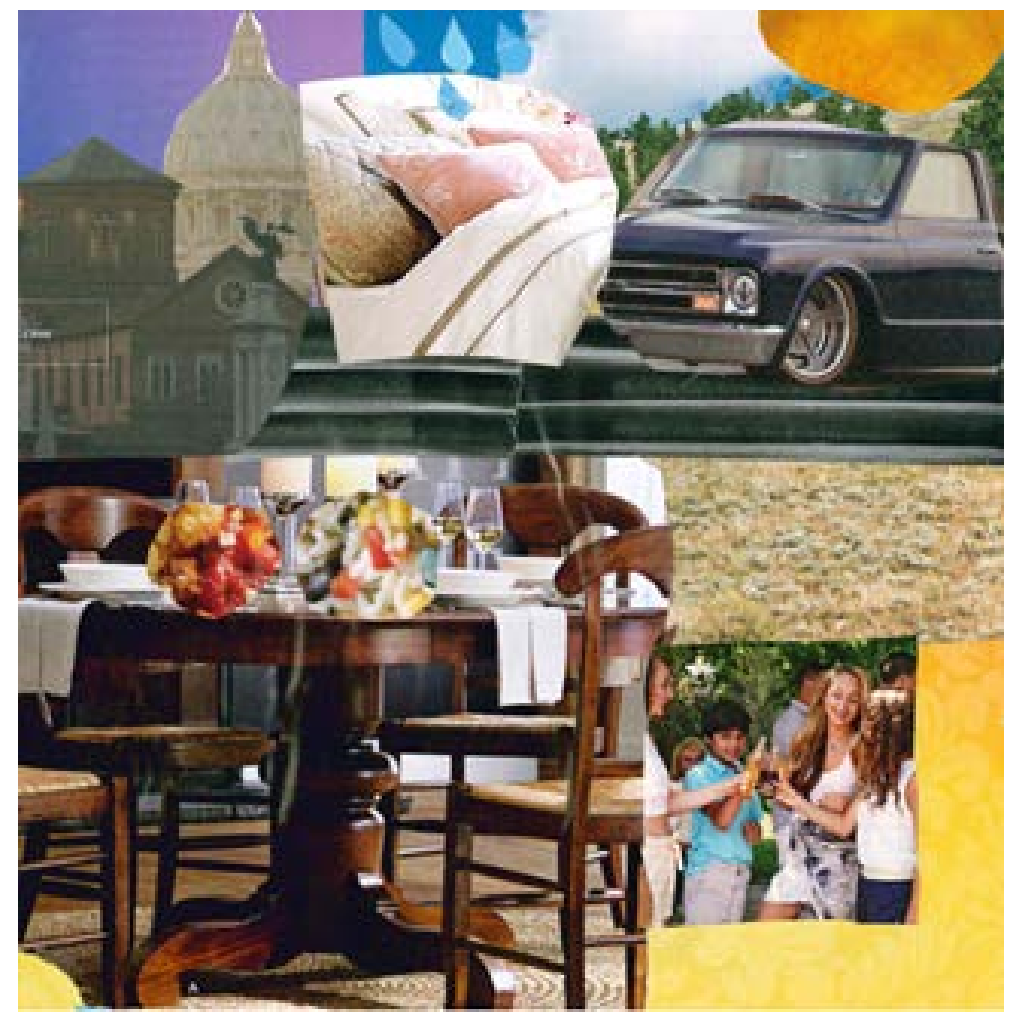

Figure 5.5. Manuel's collage, depicting his move from Mexico to the U.S. 
Similar to Manuel, Amal used warm colors in his collage (see Figure 5.6). He wrote about an accident that happened years ago in Nepal. During a fall, Amal broke his arm and spent months staying home with his dad who took care of him while mom worked. The injury was serious enough for him to go to a hospital; unfortunately, Nepali doctors couldn't help. Only after the family relocated to the United States through Kentucky Refugee Ministries, American surgeons were able to perform the surgery and Amal gained full control of his arm. He expressed his joy and happiness with life through yellow, orange, and green colors in his collage.

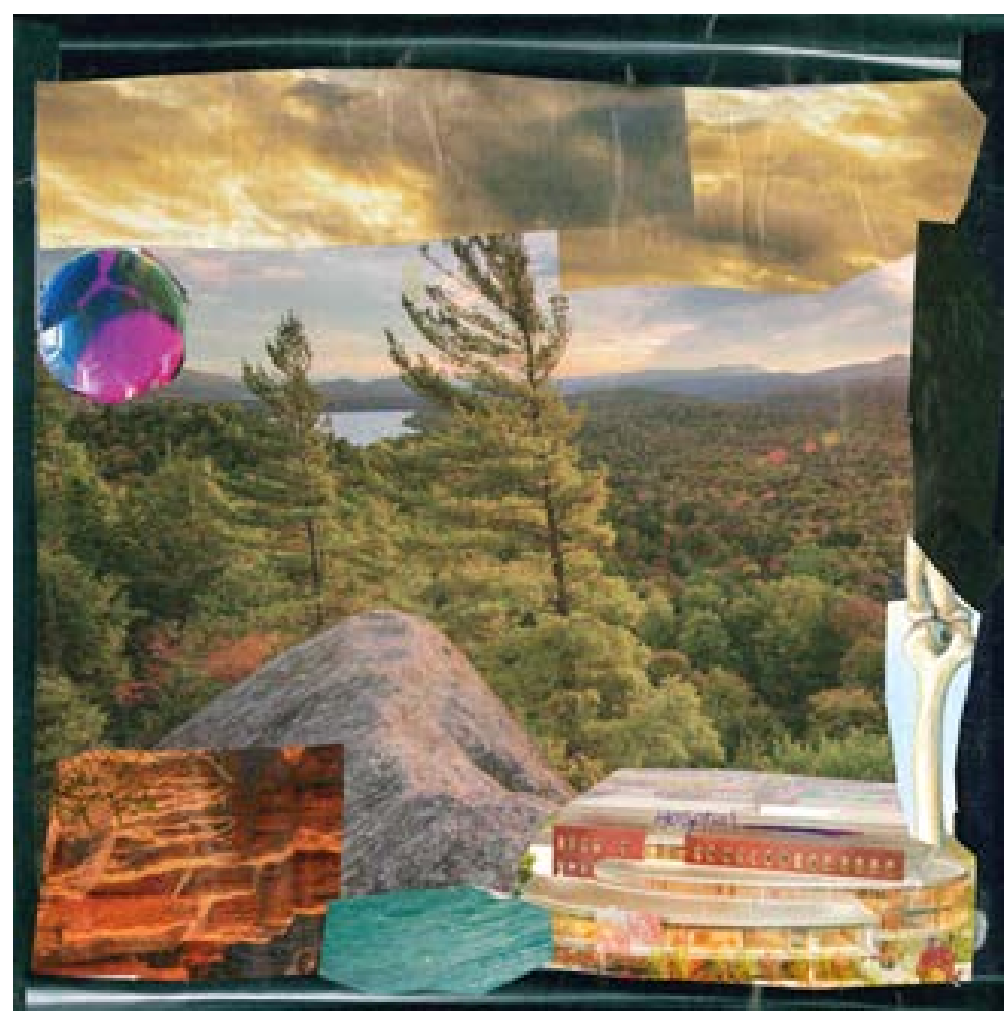

Figure 5.6. Amal's collage, depicting a childhood accident.

It appears that the loss or the attainment of values in English language learners' lives affected their emotions and consequently the color choice of the backgrounds. When students had lost what was dear to them, they expressed 
themselves through the colors black (hopelessness, depression, grief), grey (anguish, unhappiness), and navy (sadness). Whenever the values were gained back, the students incorporated the colors yellow (joy) or orange (happiness) into their collages.

An example of how a loss of values affected students' color choice is evident in Chol's collage. Chol used a picture of a house to show what he valued the most and what he had lost. He used a vertical orientation to tell his story, except he did not include any images in the top two quadrants of the collage, instead, he used colors to describe emotions (see Figure 5.7). In his interview Chol said,

I felt sad and scared. I used blue and black colors and grey to show how scared and sad I was. The house was big and it was home. We lost it and everything. No one got hurt that is why I did not put people in the collage but we lost the house. The colors show how I feel.

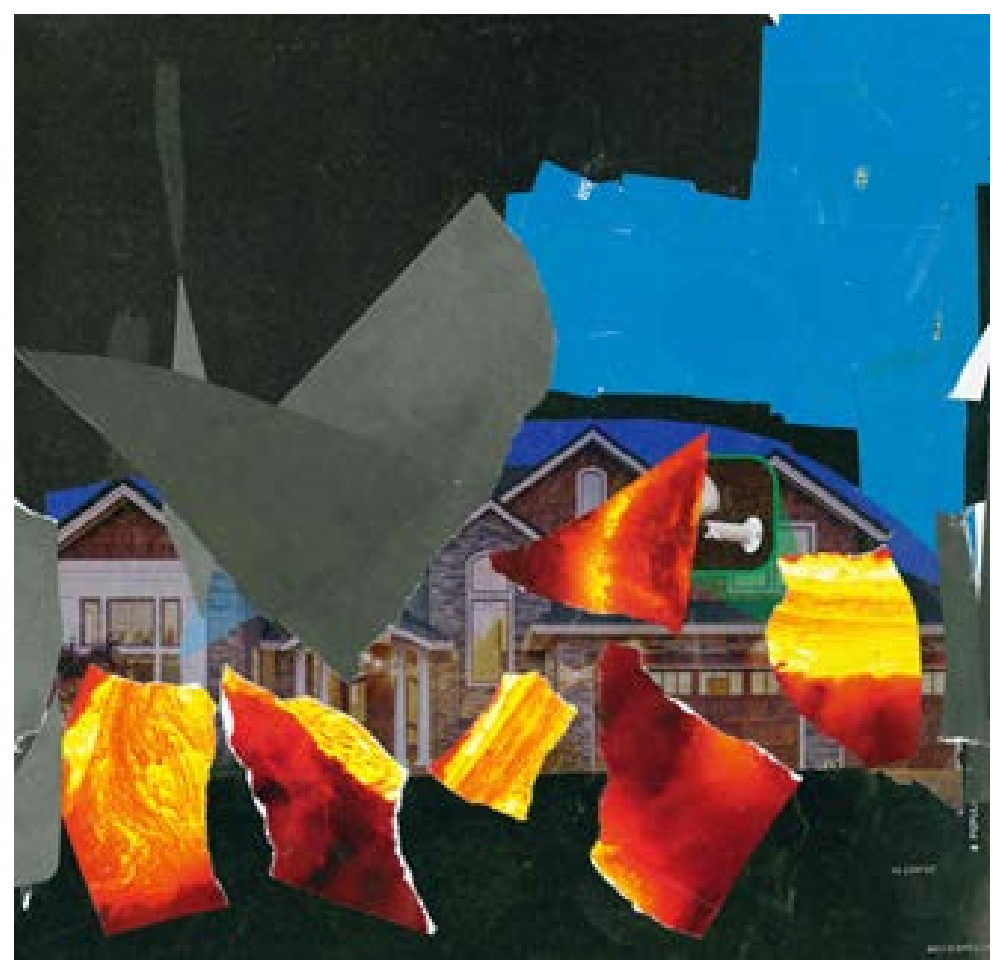

Figure 5.7. Chol's collage, depicting the house fire. 
Similar to Chol, Yoselin cut out pictures of buildings that reminded her of Mexico and placed them at the bottom of her collage with the Mexican flag just above the rooftops in the left bottom quadrant. She used navy and black colors as her background to reveal emotions (see Figure 5.8). In her narrative, she wrote:

I remember that day I was so sad because I was going to leave all my family and I knew that I would never see them again I had to leave everything I wanted and loved. It was going to be difficult for me because my whole life had been in Mexico.

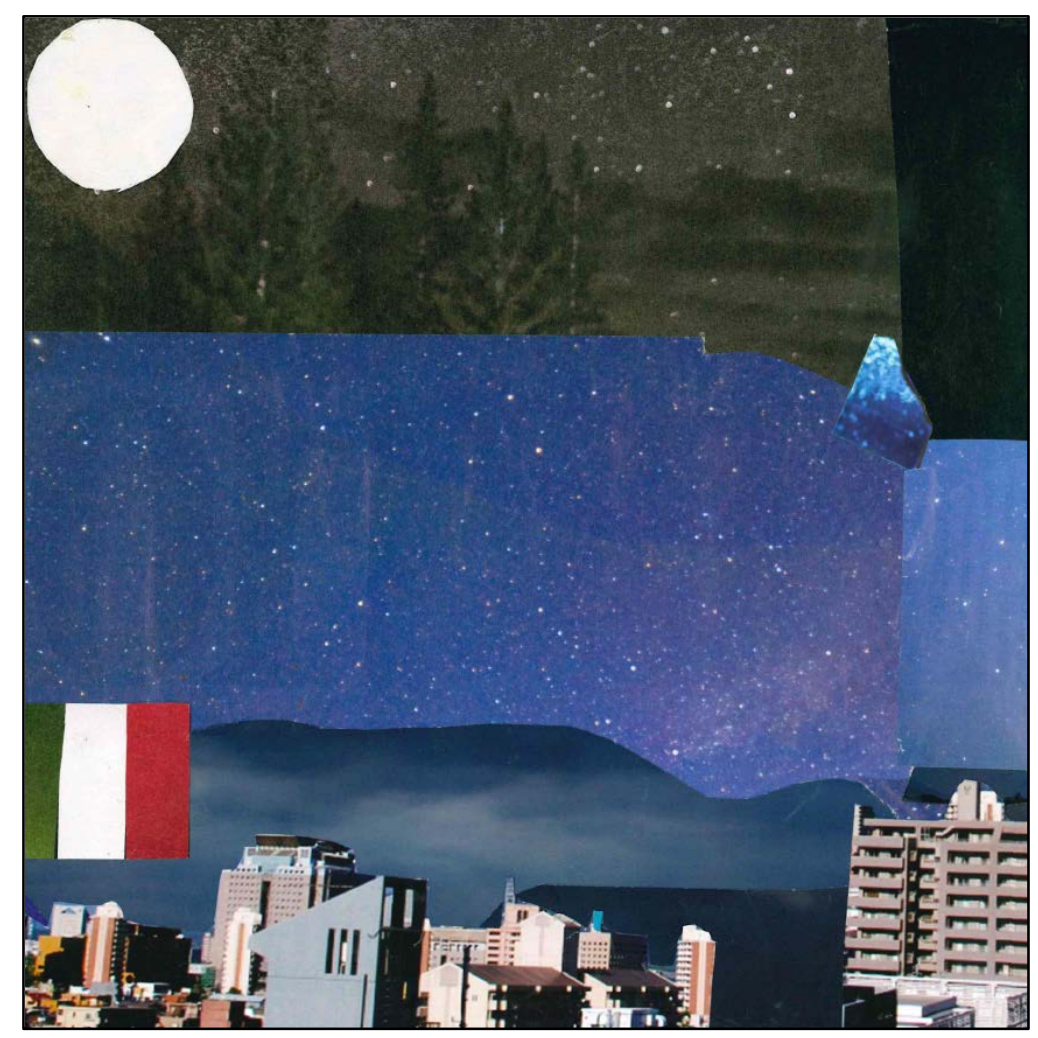

Figure 5.8. Yoselin's collage, about leaving Mexico for the U.S.

I vividly remembered Yoselin's interview; she cried the entire time.

Me: $\quad$ Tell me about your collage.

Yoselin: I like it. It helped to express myself. It is about when I came to the United States. This Mexico. And then I used blue to make it sad... 
and black.

Me: Why did you want to make it sad?

Yoselin: I came here last year [December 2016] or like four months ago. My dad, grandparents, and friends are all there.

Me: Who came with you?

Yoselin: Just my mom. She just said we have to go and l'm like okay.

Me: $\quad$ So this collage describes the day you left Mexico...

Yoselin: Yes, my last day in Mexico. Collage show how I feel. I miss so much my dad.

Me: $\quad$ Do you get to talk to him?

Yoselin: No.

Me: Do you think you will get to go back anytime soon?

Yoselin: No

Vivian also used the bottom two quadrants of her collage to tell her story. As she explained when we met, she placed a picture of a crowd in the low left corner to represent a moment in time-when she was leaving her friend's house and noticed people gathered around two women lying on the ground. Once she got closer, she realized that one of the women was her mother. She was outside during a thunderstorm and accidentally touched an electric wire that had been ripped off the electric pole by a strong gust of wind and thrown on the ground in front of the house. The picture to the right illustrates the two ambulances that took Vivian's mother and a neighbor to the hospital and several police cars that followed them. Vivian placed an image that represents her in the effective center 
of the collage. She expressed her emotions through colors: black (mourning) and violet (contemplation). She used a picture of three saints and a picture of the doves soaring in the light shining from above to illustrate her "mother's transition to the eternal life" (as Vivian called it). The picture of a beautiful cathedral represents her life in the United States. The significance of the picture also lies in its background—colored violet, which represents contemplation.

Vivian explained in the interview that she constantly thinks about her mother's death. She knows that the family would not have moved to the United States if her mother was still alive; they would have stayed in a small village in Congo. Vivian's collage does not show the ideal, per se; instead, it shows her reality and the thoughts and emotions that torment her. Vivian loves her life in the United States and appreciates the opportunities this country has to offer, yet more than anything, she wants her mother back. Did the spirits take her mother's life so that Vivian could have a better future? Is her future actually better without her mother? What would her life be if her mother was still alive? These are the questions that Vivian constantly asks herself. "I wonder" are the only words she chose to include in her collage (see Figure 5.9). 


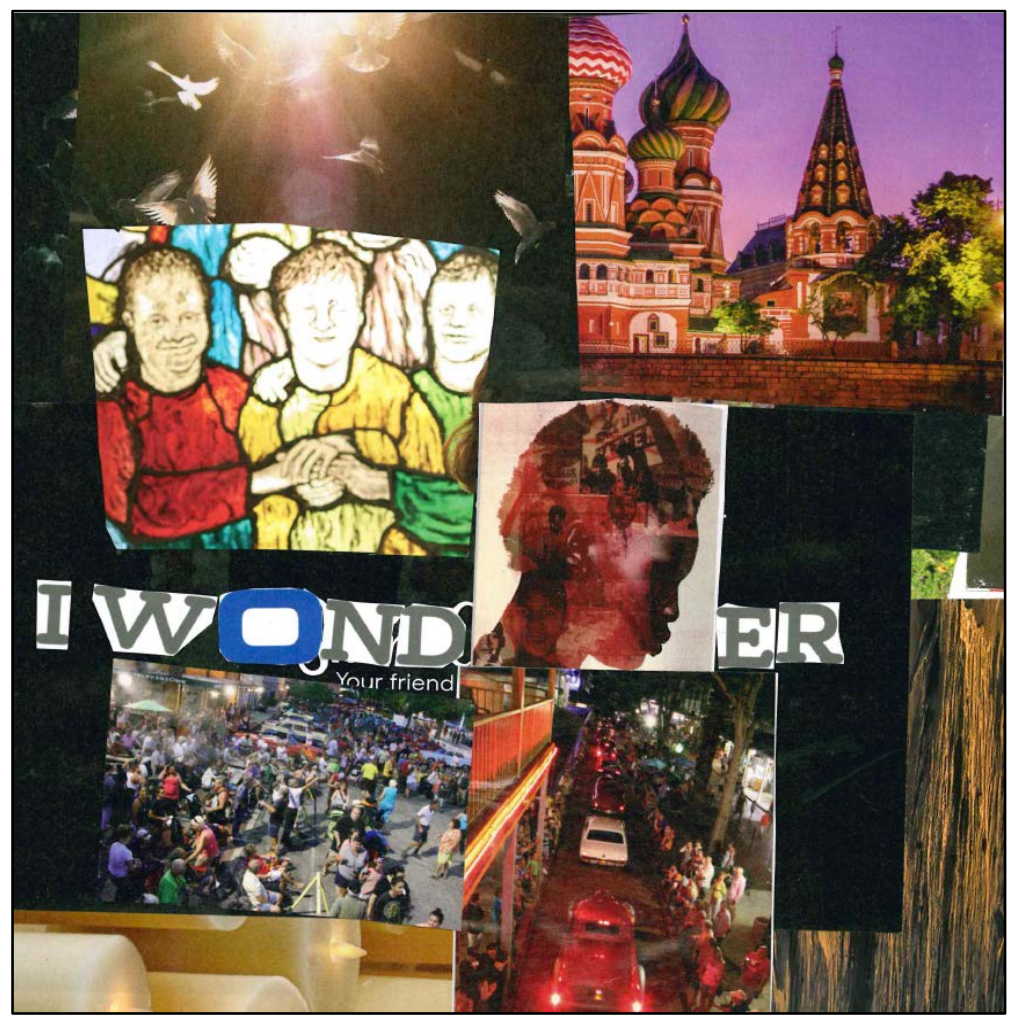

Figure 5.9. Vivian's collage, about her mother's death.

Maria's collage was similar to Alberto's. She used vertical orientation in which the ideal was represented in the top two quadrants and reality was displayed in the bottom two. Just as Alberto did, Maria wrote about their parents' separation. Even though their collages were similar in composition, Alberto and Maria were sitting at different tables and never communicated with each other during partner or group work. Maria used a black and grey background, as well as a dark tree against a brown sky and dead grass to depict the reality. However, she used bright colors, mostly different shades of blue and white, to show the life she would have loved to have. She used a picture of two adults holding hands and jumping joyfully to show her ideal world, with her mom and dad happily married. A white house in the top right corner of the collage was a 
juxtaposition of a small brown hut that she and her mother currently lived in (see

Figure 5.10). In her interview, Maria said:

It [collage] talks about how my mom was happy and dad and then on the bottom I tried to make it sad like the trees were dry. That's supposed to be my house and I liked it even though it is brown [referring to brown color representing sadness]. It's in the middle because it was how our house used to be. It was brown and all happy and big part of us, then they separated and it all just stopped. The tree is not green because I am not happy. And dark. I wanted it that way because my real is dark and not happy.

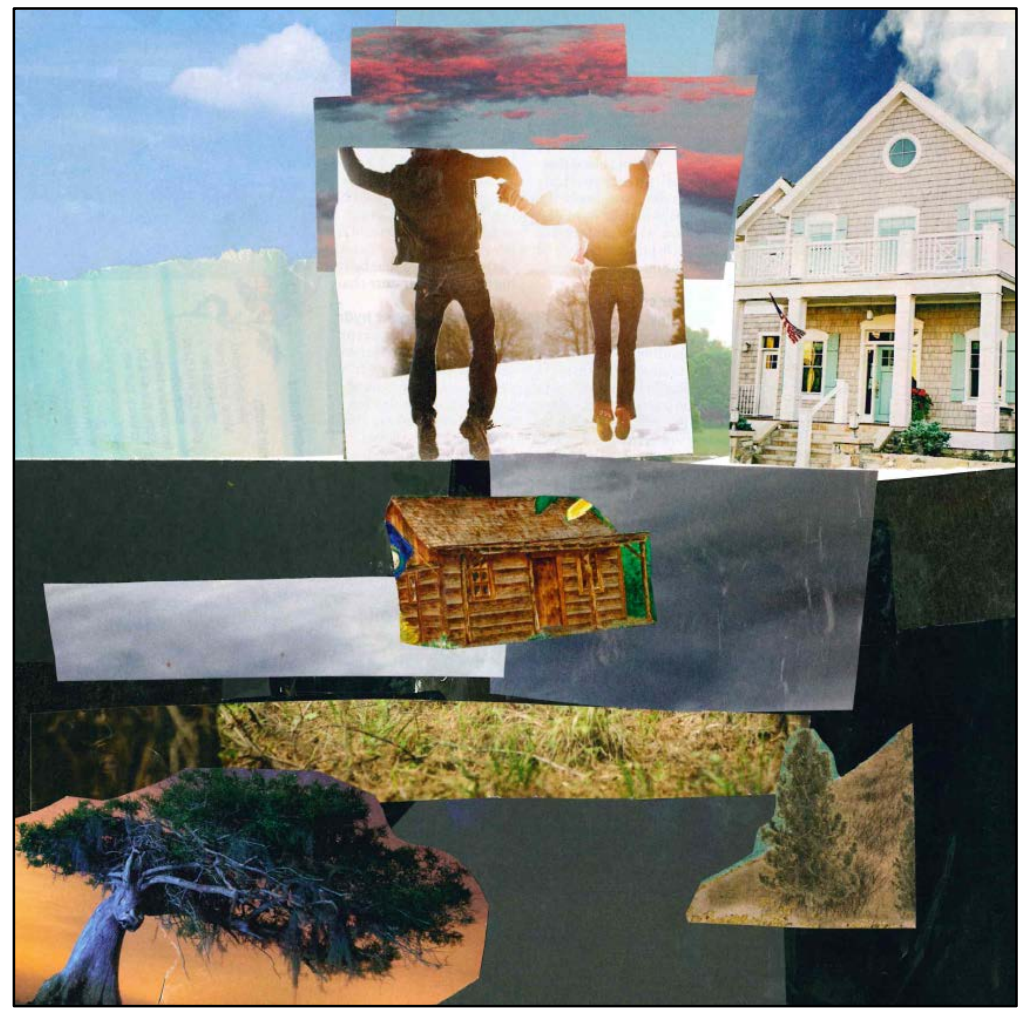

Figure 5.10. Maria's collage, about her parents' separation.

All thirteen English language learners used collages to reveal emotions about events in their lives they had no control over. During these events, the ELLs either lost or gained what was valuable to them. The students' choice of color was representative of their past and present emotions and affected by either the losses or the attainments of their values. 


\section{Achievement Emotions Related to Writing}

Writing activities were part of the language arts curriculum at Lanier Middle School and were an integral part of the ESL classroom. Thus, students in Ms. D's class were accustomed to various daily writing activities and many of the students were able to define how they felt about it. In our initial interviews, four students commented that they did not like writing or thought it was boring; one thought it was "okay" and two enjoyed or liked it.

Since writing was a recurring activity in the classroom, the students' appraisal of the activity had already happened and control and value was already established. The students expressed such a wide range of emotions about writing — from joy to hate and from liking to disliking—because they were able to determine the value of writing and establish their own capability of producing a proficient portfolio piece, as required by school and district guidelines. Those students who saw the value in writing and knew that they could successfully participate in the task, experienced positive emotions and stated in their initial interviews that they enjoyed or liked writing. For example, Marco said, "I enjoy

writing. Writing helps you do better and be a better writer. When you have a job when you grow up, you need to do well in writing." Marco saw the value in writing and felt confident in his ability to write. In the same interview he said, "I am doing better now. The body paragraphs are easy for me."

Just as his classmate did, Manuel felt comfortable with writing. In his initial interview he stated, "I like writing because l'm better at writing now and I have learned a lot about writing." He also saw the value in it, because he was 
the only one in his family who could write in English and he wrote at home for his mom.

Those students who were not interested in writing or perceived a lack of control over accomplishing the task experienced negative emotions and stated that they hated or did not like writing. Chol told me that he struggled with punctuation and did not like to write on certain topics. His lack of interest in the topic and his low self-perception as a writer led to negative emotions towards writing. Likewise, Yoselin told me that "writing in English was hard" and that it was much easier for her to write in her native language, Spanish. Even though she did not indicate in her initial interview if she assigned any value to the writing process in English, she did say that she wrote mostly in Spanish both in class and at home. This led me to believe that, at this point in Yoselin's second language acquisition, the value of an activity was determined by the type of activity she participated in. Because I believed that Yoselin saw the value in acquiring English, participation in some listening and speaking activities in class most likely evoked different degrees of positive emotions. Since she was more proficient in writing in Spanish than in English, she used her native language to express her thoughts in writing and to take notes in class; consequently, this led me to believe that Spanish was more valuable to her in writing activities than English. The combination of low controllability and value induced the negative emotions Yoselin experienced towards writing in English when she stated, "I don't like writing." 


\section{Achievement Emotions Related to Collage Making}

Collage making was a new activity for the majority of the students in class; therefore, the "appraisals of both control and value [were] necessary for an achievement emotion to be instigated" (Pekrun et al., 2007, p. 21). In the controlvalue theory, Pekrun et al (2007) posited that perceived value influences the type and intensity of emotions. Thus, if an activity or outcome is valued as positive, positive emotions are assumed, and vice-versa. In this way, the intensity of the emotion is a function of the degree of subjective value, such as the degree of interest in learning material or the perceived importance of success or failure on an exam. If a student perceives no value in an activity_implying that the activity or outcome is subjectively irrelevant-there is likely to be no positive emotion instigated (p. 22).

Prior to the collage activity, only the student who participated in the activity before was able to tell me how he felt about it, stating: "Did collage once. It's pretty fun." The rest of the class made comments such as, "I don't know about collage", "I don't know if I like it", and "Don't know how I feel about it".

After the collage activity, eleven of thirteen students chose collage making over writing and experienced strong positive emotions stating, "I enjoyed collage," and "I like collage, more funner to do." They saw the value in the activity and expressed confidence in their ability to perform the activity (see Table $5.5)$. 
Table 5.5

Students' Thoughts and Feelings about Collage

$\underline{\text { Name }}$

Thoughts and Feelings

Alberto Collage seems great. It seems fun. It's just good for to remember in the past. It was the most helpful. I would go for collage. You can cut out some stuff and put it on paper, get some background, get some ideas for what you're going to do. And I have a lot of great ideas... If I had to choose between writing and collage, I would choose this one [collage].

Maria I enjoyed making my collage because I expressed myself there. I wish we would have done more collage in the beginning of the year.

Vivian It's more funner to do and you get to be creative. Also, it's another way to express yourself. It shows more emotions. I enjoyed it.

Marco I enjoyed collage. I could express how I feel. If I had a choice between writing and collage, I would choose collage.

Isabel Doing collage was emotional but I enjoyed it the most because we could be creative. It allowed to show feelings.

Yoselin I like it the most. It helped to show how sad I was.

Fatima I enjoyed collage. It helped me to relive my happy moment in the childhood.

George I feel good about collage. It helped to describe how I felt.

Manuel The part that I really did like of this unit was collage. I enjoyed it a lot.

Olga It helped to express feelings. It helped remember the past. I feel good about collage. It just takes it out of me.

Ernesto I got to do the artwork to express feelings. I wish we could have done more of this and less bookwork, Collage was my favorite part. I enjoyed it a lot. 
Amal Collage is easier than writing and feel more emotional. I kind of felt happy and sad because I was remembering things. I enjoyed doing it.

Chol I liked collage the most. Cutting out images from magazines and gluing them on paper made me think.

These are the types of statements from students' reflections and interviews about collage that I coded as having intrinsic and extrinsic value:

- helped remember details

- brought back memories

- helped recollect past

- brought back feelings

- helped express feelings

- allowed to be creative

I coded these as examples of control:

- it is easier for me than writing

- we could use whatever we wanted

- I knew strategies to organize collage

- I have a lot of great ideas

Two out of thirteen students in class (George and Olga) stated that if they had to choose between the two modes of communication, writing and collage making, they would prefer writing. George said, "I can describe more through writing" (intrinsic value) and "What I learned in writing helped me improve for high school. I'm not going to have a lot of problems because I learned more things I didn't 
know about writing" (extrinsic value). When talking about the collage, George stated, "It helped to describe how I felt" (intrinsic value). Even though he saw the intrinsic value of the activity, he also noted a lack of control regarding some parts of the activity by saying, "When doing collage we couldn't draw something that we couldn't find that was related to our story." Similarly, Olga assigned both intrinsic and extrinsic value to writing when she said, "I can express more through writing" (intrinsic) and "learning about writing helped to get ready for school" (extrinsic). When talking about collage making, Olga stated, "It helped to express feelings. It helped remember the past" (intrinsic value). She was clear about her control over the writing activity, stating, "It's not hard if I pick the right topic. Once I get into the writing, I know what I am doing." However, she did not express how much control she had over her collage (see Table 5.6).

Table 5.6

Students Who Preferred Writing over Collage Making

\begin{tabular}{|c|c|c|c|c|}
\hline Student & Activity & Control & Value & Feelings \\
\hline George & Writing & It's kinda easy. & $\begin{array}{l}\text { I can describe more } \\
\text { through writing. } \\
\text { What I learned in writing } \\
\text { helped me improve for } \\
\text { high school. I'm not } \\
\text { going to have a lot of } \\
\text { problems because I } \\
\text { learned more things I } \\
\text { didn't know about } \\
\text { writing. }\end{array}$ & $\begin{array}{l}\text { I like } \\
\text { writing }\end{array}$ \\
\hline
\end{tabular}




\begin{tabular}{|c|c|c|c|c|}
\hline George & Collage & $\begin{array}{l}\text { When doing } \\
\text { collage, we } \\
\text { couldn't draw } \\
\text { something that we } \\
\text { couldn't find that } \\
\text { was related to our } \\
\text { story }\end{array}$ & $\begin{array}{l}\text { It helped to describe } \\
\text { how I felt }\end{array}$ & $\begin{array}{l}\text { I feel } \\
\text { good } \\
\text { about } \\
\text { collage }\end{array}$ \\
\hline Olga & Writing & $\begin{array}{l}\text { It's not hard if I } \\
\text { pick the right topic. } \\
\text { Once I get into the } \\
\text { writing, I know } \\
\text { what I am doing. }\end{array}$ & $\begin{array}{l}\text { I can express more } \\
\text { through writing. } \\
\text { Learning about writing } \\
\text { helped to get ready for } \\
\text { high school. }\end{array}$ & $\begin{array}{l}\text { I like } \\
\text { writing. }\end{array}$ \\
\hline Olga & Collage & & $\begin{array}{l}\text { It helped to express } \\
\text { feelings. } \\
\text { It helped remember the } \\
\text { past. }\end{array}$ & $\begin{array}{l}\text { I feel } \\
\text { good } \\
\text { about } \\
\text { collage. }\end{array}$ \\
\hline
\end{tabular}

Both George and Olga saw the intrinsic and extrinsic value of writing and knew that they were capable of completing the task successfully. Consequently, both students experienced positive emotions and stated that they liked writing. When asked about the collage, both students articulated the intrinsic value of the activity. The goal of the assignment, however, was to tell an audience about an event that had an impact on the students' lives. According to the students, the collage helped to express feelings but they both used writing to narrate the events in the story. Though a valued experience, the collage only partially helped George and Olga complete the assignment. And because the degree of subjective value regarding collage making was less than the students assigned to the writing activity, the intensity of positive emotion expressed was also less.

English language learners' achievement emotions about writing and collage-making varied and were influenced by how much control they had over 
the activity and how much value they appointed to writing and collage making.

\section{Ms. D's Final Thoughts}

I wanted to talk to Ms. D about the emotions her students revealed in their collages as well as the achievement emotions they shared with me in the interviews and reflections. I met with her for the final interview, which took place after the spring break. We sat in the school library during her planning period. Ms. D had already read her students' narratives and collages as well as the transcriptions of the interviews I had provided her with. Since this was not her first time using collages in an ESL classroom, I was interested in learning how different this experience was for her compared to her past experiences and if she had new insights or made surprising discoveries.

Ms. D shared with me that the unit validated her beliefs that English language learners should be allowed to use several modes to express themselves and that language is not always the right mode of communication for every classroom activity. English learners should be allowed to use drama, visual art, and various technological tools for learning and demonstrating their learning. She also said,

I was surprised at how disconnected many of my students seemed from their writing. It was clear by their writing that they learned from the lessons and included many of the writing elements we discussed like dialogue, descriptive language, leads, etc. Their writing lacked the details that showed the emotion they felt about their experiences. However, they seemed to find comfort in the collages which allowed them to freely express themselves without feeling like they were deficient.

Ms. D went on to say, "The numbers you get in the beginning of the school year [referring to the Students' 2016 WIDA ACCESS Results table] are cold and 
dangerously limiting. They label students and don't tell the real story. The narratives and collages do." When I asked her, "If you had to teach this unit again, what would you do differently?" Ms. D responded,

If I had to teach this unit again, I would not change anything as far as instruction but would change the time of the unit's implementation. I feel like this unit is best to do in the beginning of the school year and not towards the end. I learned so much about my kids from collage and how they feel. ... We assume kids that come here have a better life because it's America but we forget that many left so much behind in their home countries. I wish I had more time with them. ... I wish I learned this earlier in the year. . . I I would have been able to do so much more to help them.

Ms. D seemed distressed when she learned about her students'

experiences and emotions they harbored. The collages allowed her to enter her students' worlds and empathize with them. All of her English language learners experienced hardships and were left with memories that haunted them. Ms. D was overwhelmed by the sadness of the students' stories and wished she could have helped them; however, with the school year almost over, she was heartbroken realizing that she did not have enough time to ease their pain and build on their innate strengths to overcome the adversities in their lives.

\section{Summary}

The English language learners in Ms. D's classroom employed two communicative modes to tell their difficult stories. They used writing to describe events in their lives and collages to reveal emotions. Both modes complemented each other and allowed the students to describe an experience that impacted their lives and identity development as well as reveal strong emotions. The students' choice of color for their collages was affected by either the losses they had suffered or the attainments of values they had gained. 
English language learners' achievement emotions about writing and collage making varied and were influenced by how much control they had over an activity and how much value they appointed to writing and collage-making. The students who did not feel positively about writing struggled with language and did not assign importance to the act of writing. These students voiced issues of control over the words and with formulating concepts through narrative. Collage making was new for most of the students and therefore engaged them more and allowed them to experience a new mode to express themselves.

In the next chapter I will summarize the conclusions of the study, discuss conditions for creating effective instruction for ELLs, implications for policy and practice, and limitations of the study. 


\section{CHAPTER VI: DISCUSSION}

"Almost anyone who has spent time in a classroom can attest that the felt and expressed emotions, and the emotional dynamics of groups, shape the project of learning and the classroom environment" (Boler, 1997, p. 203).

Language has played a dominant role in education for years. Although many elementary school teachers encourage literacy learning through the arts, secondary schools predominately focus on literacy learning through language. Leland and Harte (1994) noted years ago that, "Historically, language arts programs have been largely verbocentric, focusing more on 'language' than on 'arts'” (p. 337). This is particularly challenging for English language learners. The predominance of activities that involve the use of oral and written English language can leave ELLs feeling overwhelmed and frustrated by their inability to communicate fully with others and may cause these students to develop negative emotions towards language-based activities. A verbocentric curriculum can negatively affect the self-esteem of English language learners because it restricts their ability to share their thoughts and learning. In turn, low self-esteem can have a negative impact on classroom behavior, desire to learn, academic performance, and ability and willingness to overcome challenges and take risks. It also has a bearing on how fast and successful ELLs can acquire English.

Proficiency in English induces various emotions in students about themselves as learners and amplifies emotions towards those who are involved 
in their learning, such as teachers and peers. Students who are at the lower level of English proficiency pay close attention to the facial expressions and tone of voice of people around them. They do that to help them understand the messages of others in a language in which there they are not yet proficient. They also become acutely aware of their own emotions, including emotions about classroom activities and topics discussed in class. Unfortunately, such students are not always willing or capable of revealing those emotions unless they are taught how and are encouraged to bring their emotions to light through writing that is connected to other forms, such as art, music, and drama. According to Eisner (2002), children's "conscious realizations that form can be manipulated to express feelings comes late in childhood" (p. 82). Many learn it in pre-school, unfortunately English language learners' educational backgrounds differ from that of their non-ELL peers and their schooling may or may not have included various communicative modes and supported the connection between "form" and "feelings". Exposing ELLs to arts-based learning and intentionally focusing on "nurtur[ing] appreciative, reflective, cultural, participatory engagements with arts by enabling learners to notice what is there to be noticed" (Green, 2001, p. 6) are essential to the development of the students' aesthetic experiences. These experiences "heighten feelings" (Eisner, 2002, p. 81) and allow for emotional expression without the use of language.

In this study, the collages became an aesthetic experience that enabled students to connect with their own pasts and simultaneously "discover the contours of [their] emotional selves" (Eisner, 2002, p. 11). This discovery 
happened during the process of creation and in moments of reflection. As Maxine Greene (1995) wrote, "Teachers must emphasize the importance of persons becoming reflective enough to think about their own thinking and become conscious of their own consciousness" (p. 65). Collage making as an activity stimulated reflection and encouraged the capturing of one's own thoughts, allowing the students to identify and name the specific emotions they experienced and to express them artfully on paper. This served an educational purpose and was therapeutic for the students, as it gave them a chance to remember and reconnect with their lived experiences. Collage making conjured memories and reminded students that their pasts were filled with both negative and positive emotions. Although collage making did not alleviate the sadness in some of the students' current realities, it gave them an opportunity to reexamine the events in their lives and to reflect upon their significance. Many of the students appreciated the chance to go back and experience the joy they had felt when surrounded by loved ones in a place they used to call home. In their final interviews, students acknowledged the important role collage making played in allowing them to reconnect with the people and places from their past. The use of visual images, colors, lines, and shapes made certain relationships vivid for the students and helped them notice and understand their place in them (Eisner, 2002). Introducing art into language arts thus provided students with a way to communicate their thoughts and, correspondingly, increased their self-esteem.

This phenomenon was present in Ms. D's classroom from the moment the arts-based unit began until the very last day. It was filled with emotions-ranging 
from excitement and joy to frustration and sadness, varying from student to student and from one activity to the next. As Ms. D introduced students to narrative writing and collage making, they revealed different emotions as they reminisced on their prior experiences with each part of the assignment. Because it was a recurring activity, the students had preconceived notions about writing. They appointed intrinsic and/or extrinsic values to the activity before they participated in it. Collage making was a new activity for most of the students; consequently, the arts-based unit became key in their control-value appraisal of it (Pekrun et al., 2007). The students who expressed uncertainty about collage making in the beginning of the unit ultimately developed an appreciation for this communicative mode and described it as fun and exciting.

During the writing portion of the assignment, a lack of language proficiency in English posed a communicative challenge for the English language learners and made it difficult for them to describe their emotions using language as the sole mode of expression. When given two modes of communication and representation, students chose written language to describe the sequence of events in their stories and used collages to express their emotions. Accompanying writing with collage making made it possible for students to accomplish the assignment because their ability to complete the project was not entirely tied to their English language proficiency. The students who had never made a collage before and were unsure about how they would feel about it, experienced strong positive emotions towards collage making once they had done it. In the end, the majority of the students stated that they enjoyed working 
on the collage and that it had become their preferred mode of communication and representation. When the students assigned more value to collage making, they experienced stronger positive emotions, and when they appointed less value to the activity, they experienced positive emotions to a lesser degree. Out of a class of thirteen students, two favored writing, perhaps because they were at a higher level of English proficiency and they understood the intrinsic and extrinsic values of writing in English due to their control in communication when using written language. Thus, it resulted in these students experiencing much stronger positive emotions towards writing compared to collage making.

Whether the students chose language or collage making as their preferred communicative mode, the students agreed on the existence of the intrinsic value of collage making, which manifested itself in the various colors and images that the students used to depict how they felt about past and present experiences. They felt that its composition triggered memories and allowed for the recall of the details. This was evident when the students were working on the activity: Even though it permitted student dialogue and sharing, the students stayed silent as they took time to remember and reflect and be alone with their emotions. Collage making became essential in mediating those memories and emotions while enabling students to examine carefully their thoughts and make feelings visible to others (Eisner, 2002). When students felt a lack of control over an experience such as their parents' separation or moving to the United States and they experienced a loss of certain values, negative emotions prevailed. In these situations, they chose dark colors and images to capture those emotions on 
paper and, through creative self-expression (Eisner, 2002), they shared them with the audience. When the students felt a lack of control but eventually retained their values or found new values in life, they experienced happiness and joy and revealed their emotions through warm colors and cheery images.

Collage and narrative writing served different purposes but complemented each other in delivering a message. If Ms. D had not integrated collage making into the curriculum and had not taught her students about colors, lines, and shapes, she most likely would not have seen the intense emotions behind each student's experience and their stories would have been incomplete.

\section{Creating Conditions for Effective Instruction for ELLs}

The implementation of quality instruction for English language learners has implications for its overall effectiveness in enhancing ELLs' literacy and language learning. It is important to remember that emotions are integral to the classroom and that they have a significant impact on learning and motivation. Levels of English language proficiency evoke different emotions in English language learners regarding classroom activities. The more proficient students are in a non-native language, the more able they are to successfully participate in a language-based activity and, consequently, the more likely they are to experience positive emotions regarding the activity. Students' engagement with an activity and the desire to participate in similar future activities are all determined by how much control English language learners have over an activity and how much value they assign to it. If students assign positive value to an achievement activity and perceive it as being sufficiently controllable by them, 
they will most likely be willing to engage with a similar activity in the future. If ELLs do not appoint neither intrinsic nor extrinsic value to an activity and they do not view an activity as controllable, they, most likely, will experience negative emotions and be less willing to engage with the activity, or similar activities, in the future.

Just as emotions impact student achievement, various communicative modes do as well. Therefore, it is essential to provide English language learners with information about and access to alternate ways of learning and sharing learning. Once ELL students understand how non-language based forms of communication can help them express their thoughts without language, they are more likely to perceive themselves as capable. Because each mode-including dance, music, and visual art-is unique, the more students know about the features of each, the more informed they will be of their choices to represent meaning in a particular way to ensure they pick the mode that best suits their interests and aptitudes (Eisner, 2002). Explicit teaching of communicative modes and class discussions about their usefulness can help ELLs understand and appreciate what is available to them so that they can employ an appropriate mode for a specific purpose. Using one mode of communication and representation is not enough to gain insight into English language learners' experiences, learn their thoughts and understand emotions. Providing students with a combination of communicative modes allows for a more insightful communication. 
Work with ELLs demands quality curriculum that fosters resiliency and allows students to read about children and adults who found themselves in difficult situations and had to overcome challenges before and after their move to the United States. Learning from others' experiences can help students cope with their emotions and provide them with the strength to overcome obstacles and recognize all the positives in their own lives. Many students are capable of bouncing back from tragic events on their own, while others need support in the recovery process. Through quality curriculum and class activities teachers can help students uncover their innate resiliency and develop a better outlook on life.

Creating conditions for effective classroom instruction for ELLs involves acquiring pertinent knowledge about the students, teachers becoming experts in the content they teach and instructional strategies they use in their teaching, and school leadership supporting and valuing diversity and capitalizing on students' funds of knowledge (Moll, Amanti, Neff, \& Gonzalez, 1992). Even with all the supports in place, the best designed instruction may fail if the following barriers continue to exist:

- Failure to teach ELLs self-advocacy. Students need to be aware of the policies and laws that are in place to protect them and ensure equal access to education. This includes students' knowledge of Program Services Plans and accommodations they are entitled to so that they can ask for these accommodations in mainstream classes. It is important for ELLs to recognize their own abilities and develop an understanding of their own needs. Students' knowledge of how 
accommodations can help them address those needs will allow ELLs feel more in control of classroom activities and, when needed, be more inclined to ask teachers for accommodations.

- Failure to recognize the importance of class discussions regarding values of academic engagement. If students struggle to see the value of a classroom activity, they will be less inclined to engage with that activity and less likely to experience positive emotions. Similarly, if English language learners fail to see the intrinsic and/or extrinsic value of communicative modes, they will be less willing to utilize that mode in the future. As Pekrun (2006) states, "[positive values] should be fostered and negative values prevented. Teachers, parents, and peers deliver direct, verbal messages about academic values, as well as more indirect messages conveyed by their behavior, and by the learning assignments provided to students" (p. 334). Meaningful assignments that promote content learning and the advancement of ELLs' language skills can help the development of positive values.

- Overreliance on language as a sole mode of communication;

- Marginalization of other communicative forms: digital, visual, musical, etc.

- Failure to give students autonomy. Autonomy in the classroom can be supported through student choice. Student choice can include student choice of communicative modes_-for example, the use of collages in an ESL classroom instead of or in addition to writing—or student 
choice of group work versus independent work. Lev Vygotsky (1978/1930-1934) proposed a concept of "zone of proximal development"-a space where students learn through collaboration with other students or teachers. When English language learners participate in an activity that requires the use of language or other communicative mode they are not yet proficient at, they may perceive themselves as less capable of completing the activity independently. Working with a peer or in collaborative groups within the "zone of proximal development" can help them see the activity as achievable and help them learn more.

\section{Implications for Policy and Practice}

Education of English language learners is impacted by policies that ensure equitable access to instruction and materials. The instruction that many ELLs receive is different than that of English-speaking peers due to their need to master language along with content. It is important that ELLs receive numerous opportunities to practice their oral language skills by engaging in academic conversations with peers through partner work or in collaborative groups. Spending quality time on perfecting their reading, writing, and listening skills is key to the students' obtainment of proficiency in English as well. There are no shortcuts to learning a language and it would be unrealistic to expect all ELLs to reach proficiency in English within a specific period of time. Each child is unique and learns at his own pace; furthermore, strategies that support academic growth of one English learner may not be as effective in advancing language skills and 
content learning of another student. What matters to all ELLs is quality instruction that encompasses a variety of strategies and approaches including a multimodal approach to teaching and learning.

Several years ago the U.S. Departments of Education (ED) and the U. S. Department of Justice (DOJ) released a guidance document "reminding states, school districts and schools of their obligations under federal law to ensure that English learner students have equal access to a high-quality education and the opportunity to achieve their full academic potential" (U.S. Department of Education, 2015). The document is an important step in bringing attention to the current state of affairs regarding students who speak English as other language; however, there is more that needs to be done.

- Policymakers could re-evaluate and redesign what is currently considered effective instruction for ELLs in order to increase opportunities for students to use various communicative modes. The growing prevalence of multimodality in everyday life should be more visible in the school curriculum. Instead of cutting the budget and minimizing already limited access to the arts education, policymakers need to ensure the employment of multiple modes for instructional supports to help advance ELL academic achievement and cultivate creativity.

Imagination is essential to child development, and as students grow older, it becomes instrumental to the learning process. When students apply their imagination to something concrete, they develop creativity, 
which is essential to one's success in today's world. Businesses look for people who are unique and who are able to generate innovative ideas and "display advanced aesthetic judgment and see problems through new perspectives" (Acerm \& Omeroðlu, 2007, p. 336). Today, when most activities in content classrooms emphasize literal language and hard facts, collage making offers a creative alternative; it gives students the chance to use their imaginations and contributes to the development of their aesthetic selves. Many scholars such as Green (2001), Eisner (2002), and Dewey (1934) recognize the importance of this. In Art as Experience, Dewey (1934) wrote that, "Aesthetic cannot be sharply marked off from the intellectual experience since the latter must bear an aesthetic stamp to be itself complete" (p. 40).

- States and districts could identify and develop expert resource teachers to support the development of multimodal curriculum and its implementation at the school level. These experts can provide professional development opportunities and one-on-one coaching to teachers to ensure a successful transition from language-based to multimodal instruction of ELLs. Research has shown that when teachers use a combination of modes, student literacy learning and level of engagement improve (Guichon \& McLornan, 2007; Early \& Marshall, 2008; Wei, 2011; Archer \& Newfield, 2011). Multimodality provides students with options for communication and allows them to access identities of experts (Ajaya, 2009; Black, 2009; Wilson et al., 
2012, Nteliglou et al., 2014). Incorporating research-based multimodal practices will ensure that school curriculums are connected with outside-of-school arts, multimodal, and $21^{\text {st }}$ century practices that students engage themselves in. As Albers and Sanders (2010) pointed out, educators "have the responsibility to provide students with a range of opportunities that enables them to expand their repertoire of ways in which they can communicate what and how they know" (p.3). The shift to multimodal curriculum will make the transition easy when policymakers accept their part of responsibility and give attention to the impact of multimodality on fostering the expansion of English language learners' literacy and identity development as well as language and content learning.

- States and districts could secure funds to support summer institutes and workshops for teachers designed to provide foundation for ongoing learning on effective instruction for ELLs. Teaching methods play an essential role in student investment in a subject and desire to excel at it. The more they are aligned with learners' everyday experiences and connect with "the everyday literacies students bring into the classroom" (Albers \& Sanders, 2010), the better of a chance teachers have at reaching all their students. By introducing teachers to various modes of communication and representation and providing them with multiple opportunities to practice them, teachers of ELLs will be able to experience first-hand all the advantages these modes bring 
to teaching and learning. In order for teachers to start incorporating these forms into their teaching, they have to learn how to use them first. Teachers are like students and need a supportive learning environment to take risks and be able to step out of their comfort zones to explore and experiment. As Albers and Sanders (2010) noted, "teachers who lack skills or experience with the arts or new literacies are a lot like struggling readers-they avoid what they are not good at" (p. 18). Consequently, summer institutes and workshops will ensure teachers' hands-on, collaborative learning experiences necessary to successfully incorporating multiple communicative modes into their teaching.

Emotions are pivotal to student psychological health and well-being and their influence on student learning and achievement cannot be overlooked (Pekrun, 2006). English language learners come from diverse cultural backgrounds and their educational histories differ. Some students were exposed to and have had classroom experiences similar to ones in the United States. Other students came from educational backgrounds that were different; therefore, their emotional reactions to certain activities may differ as well. For instance, some ELLs' test anxiety may be higher than their classmates'. Students may also react differently to various communicative modes. For some ELLs an activity that requires the use of English language may not be as stressful as for the others. Nevertheless, in order to address the needs of the students, teachers and policymakers need to be aware of these educational 
differences and be ready to attend to their emotions regarding classroom activities, materials, and curriculum topics. Without proper training, teachers may not know how to deal with negative emotions and provide their students with:

The cognitive and motivational quality of classroom instruction, [where] cognitive quality is defined by structure, clarity, task difficulty, and the match between task difficulty and students' competencies. Wellstructured, clear instruction and use of moderately challenging tasks promote students' understanding. As a result, students experience an increase of self-confidence and enjoyment, and a reduction of boredom and anxiety. (Pekrun, 2014, p. 20)

Consequently, policymakers could secure funds for competency trainings for teachers that focus on literacy, cultural and educational differences, and emotions. Becoming familiar with ELLs' educational backgrounds, including schooling and grading systems, could help teachers better understand their students' emotions and make their transitions to the U.S. education system easier for the students.

\section{Limitations of the Study}

The current study focused on the role that collages played in an English as a Second Language classroom and its value to English language learners as a communicative mode. The study took place in an eighth grade ESL classroom and involved thirteen students who spoke English as other language. Even though theoretically, the findings of the study can be generalized to any middle school grade level—sixth through eighth—it is unknown if the present findings will be applicable for elementary and high school level English language learners. Furthermore, it is unknown if a larger sample of ELLs would yield the same results. One of the possible limitations to the study was the presence of an iPad and several tape recorders in the classroom, of which the students were acutely 
aware. During the first week of fieldwork, the students kept asking me if I was taking their pictures or videotaping conversations, and they appeared anxious in the presence of the iPad and the tape recorders I used to record group conversations. Every time I turned the recorders on, the students would either get quiet or lower their voices so it would be difficult to hear their utterances. I tried to make the students feel comfortable; however, there is a possibility that despite of my efforts, the students still felt self-conscious and unable to fully reveal their thoughts and emotions.

\section{Conclusion}

Emotions in education have been overlooked because teaching has been viewed as primarily a cognitive activity (Boler, 1999). This study reveals the power of emotions in an ESL classroom and the impact emotions have on English language learners. Additionally, the study highlights the important role that collages play in an ESL classroom and the value of collage making to English language learners, as a communicative mode.

English language proficiency levels can be a deciding factor in how English language learners feel about an activity. Students who are at the beginning stages of acquiring English may feel less in control of languagecentered activities, yet feel empowered by activities that involve the use of other expressive modes, such as collage making. The overreliance on language as the sole mode of communication and representation in classroom activities may limit students' expression of thought and demonstration of their knowledge. 
If we want English language learners to experience positive emotions towards school and enable their meaningful participation in all classroom activities, then perhaps it is time for educators and policy-makers to re-examine "effective instruction" for English language learners. The current state of academic achievement for ELLs versus native English speakers necessitates a shift in how we educate ELLs. Language-based programs and activities, although critical to students' attainment of English proficiency, are not sufficient. The current data on English language learning supports the fact that, although students are learning and moving towards proficiency, progress is slow. Until ELLs reach a certain degree of language proficiency and develop confidence in their ability to manipulate the English language, participation in state assessments that rely solely on language and on the students' achievement of proficiency on those assessments is unattainable for many ELLs. This begs the question-why continue to rely on language-based instruction and assessments, knowing that newcomers to the U.S. and ELLs at the beginning stages of English proficiency will not be able to demonstrate their content learning and do well, even when provided with certain accommodations?

Although there is a current transition towards multimodality, resulting in changes to literacy education, there remains a valid concern as to why various communicative modes are still considered inferior to language. These changes are occurring at the classroom level and not at the administrative level. Why are we not utilizing those modes when creating district curriculums and state assessments? The overreliance on language is challenging not only for ELLs, 
who must demonstrate what they have learned; it can also promote negative emotions, due to lack of control, when using the English language. Additionally, many teachers experience negative emotions towards language-based curriculums and assessments because they do not cater to the educational needs of their ELL students. Therefore, it may be time to begin focusing on emotions in education and to equalize various communicative modes to ensure that English language learners receive an education that facilitates both learning and acquisition. 


\section{REFERENCES}

Acer, D., \& Ömeroðlu, E. (2008). A study on the effect of aesthetic education on the development of aesthetic judgment of six-year-old children. Early Childhood Education Journal, 35(4), 335-342. doi:10.1007/s10643-0070193-4

Ahmed, S. (2014). The cultural politics of emotion (2nd. ed.). Edinburgh, Scotland: Edinburgh University Press.

Ajaya, L. (2009). English as a second language learners' exploration of multimodal texts in a junior high school. Journal of Adolescent \& Adult Literacy 52(7), 585-595.

Albers, P. (2007). Finding the artist within: Creating and reading visual texts in the English language arts classroom. International Reading Association.

Albers, P., \& Sanders, J. (2010). Literacies, the arts, and multimodality. Urbana, IL: National Council of Teachers of English.

Albers, P., Holbrook, T., \& Seely Flint, A. (2014). New methods of literacy research. New York, NY: Routledge.

American Educational Research Association. (2016). Trending Research Topics. Retrieved from http://www.aera.net/Newsroom/Trending-Research-Topics

American Immigration Council (2015). An Overview of U.S. Refugee Law and Policy. Retrieved from http://www.immigrationpolicy.org/justfacts/refugees-fact-sheet

American Immigration Council (2015). New American in Kentucky. Retrieved from http://www.immigrationpolicy.org/just-facts/new-americans-kentucky

Archer, A., \& Newfield, D. (2014). Multimodal approaches to research and pedagogy. New York, NY: Routledge.

Barone, T., \& Eisner, E. (2012). Arts based research. Thousand Oaks, CA: SAGE. 
Batchelor, K. (2014). Investigating transmediation in the revision process of seventh grade writers (Doctoral dissertation, Kent State University). Retrieved from https://etd.ohiolink.edu/letd.send_file?accession= kent1404761683\&disposition=inline

Bezemer, J., \& Kress, G. (2008). Writing in multimodal texts: A social semiotic account of designs for learning. Written Communications, 25(2), 166-195.

Black, R. (2009). English-language learners, fan communities, and 21st-century skills. Journal of Adolescent \& Adult Literacy, 52(8), 688-697.

Blizzard Entertainment (2004). World of Warcraft [Video Game]. Retrieved from http://us.battle.net/wow/en/legion/

Bogard, J., \& McMackin, M. (2012). Combining traditional and new literacies in a $21^{\text {st }}$-century writing workshop. The Reading Teacher, 65(5), 313-323. doi:10.1002/TRTR.01048

Bogdan, R. C., \& Biklen, S. K. (2007). Qualitative research for education: An introduction to theories and methods. Boston, MA: Pearson.

Boler, M. (1997). Disciplined emotions: Philosophies of educated feelings. Educational Theory, 47(2), 203-227. doi:10.1111/j.17415446.1997.00203.x

Boler, M. (1999). Feeling power: Emotions and education. New York, NY: Routledge.

Brouillette, L. R., Burge, K., Fitzgerald, W., \& Walker, P. (2008). Teaching writing through the arts in urban secondary schools: A case study. Journal for Learning through the Arts, 4(1), 1-28.

Carrillo Syrja, R. (2011). How to reach and teach English language learners. San Francisco, CA: Jossey-Bass.

Creswell, J. W. (2013). Qualitative inquiry \&research design: Choosing among five approaches. Thousand Oaks, CA: SAGE.

Cultural Orientation Resource Center. (2016). About refugees. Retrieved from http://www.culturalorientation.net/learning/about-refugees\#7

Cummins, J. (1979). Cognitive/academic language proficiency, linguistic interdependence, the optimum age question and some other matters. Working Papers on Bilingualism, 19, 121-129.

Cummins, J. (2006). Multiliteracies and equity: How do Canadian schools measure up? Education Canada, 46(2), 4-7. 
Dema. A. (2015). The development of language and identity: A sociocultural study of five international graduate students living in the U.S. (Doctoral dissertation, University of Nevada, Las Vegas). Retrieved from http://digitalscholarship.unlv.edu/cgi/viewcontent.cgi?article=3472\&context $=$ thesesdissertations

DeOlivera, L. (2016). Teaching as a Top Education Policy Priority. TESOL Blog. Retrieved from http://blog.tesol.org/teaching-as-a-top-education-policypriority/

Dewey, J. (1934). Art as experience. New York, NY: Penguin.

Dyson, A. H. (2001). Donkey Kong in Little Bear country: A first grader's composing development in the media spotlight. The Elementary School Journal, 101(4), 417-433.

Early, M., \& Marshall, S. (2008). Adolescent ESL students' interpretation and appreciation of literary texts: A case study of multimodality. Canadian Modern Language Review, 63(3), 377-397.

Education for All Global Monitoring Report. (2006). Understanding of literacy. Retrieved from http://www.unesco.org/education/GMR2006/full/ chapt6_eng.pdf

Edwards-Groves, C. (2011). The multimodal writing process: Changing practices in contemporary classrooms. Language and Education, 25(1), 49-64. doi: $10.1080 / 09500782.2010 .523468$

Ehrenworth, M. (2003). Literacy and the aesthetic experience: Engaging children with the visual arts in the teaching of writing. Language Arts, 81(1), 43-51. Retrieved from http://www.jstor.org.echo.louisville.edu/stable/pdf/ 41484176.pdf

Eisner, E. (2002). The arts and the creation of mind. New Haven, CT: Yale University Press.

Erikson, E. H. (1994). Identity and the life cycle. New York: W.W. Norton.

ESSA (2015). Every Student Succeeds Act of 2015, pub. I. no. 114-95 § 114 stat. 1177 (2015-2016).

Frankel, S. (2011). Picturing writing: Fostering literacy through art@ AEMDD research findings 2007-2010. Retrieved from http://www.picturingwriting.org/pdf/AEMDDFindings.pdf 
Frankel, S., Olshansky, B., \& Yang, J. (2015). Picturing writing/image-making integrated curriculum model: Evaluation of an alternative art-and-literaturebased approach to literacy learning. Retrieved from http://rmcresearchcorporation.com/portsmouthnh/wpcontent/uploads/sites/2/2015/06/PW_FinalReport.pdf

Gee. P. (1989). What is literacy? Journal of Education, 171(1), 18-25.

Gee, P. (2004). Situated language and learning: A critique of traditional schooling. New York, NY: Routledge.

Gee, P. (2010). The new literacies: Multiple perspectives on research and practice. Guilford Press, pp. 165-193. Retrieved from http://www.jamespaulgee.com/pubdisp.php?id=0\&scateg=Linguistics

Glesne, C. (2011). Becoming qualitative researchers: An introduction (4th ed.). Boston, MA: Pearson.

Greene, M. (1995). Releasing the imagination: Essays on education, the arts, and social change. The Jossey-Bass education series. San Francisco, CA: Jossey-Bass.

Greene, M., \& Lincoln Center Institute. (2001). Variations on a blue guitar: The Lincoln center institute lectures on aesthetic education. New York, NY: Teachers College Press.

Guichon, N., \& McLornan, S. (2007). The effects of multimodality on L2 learners: Implications for CALL resource design. Science Direct, 36(1), 85-93.

Gumperz, J. (Ed.). Language and social identity. Cambridge, MA: Cambridge University Press.

Harste, J. (2003). What do we mean by literacy now? Voices from the Middle, 19(3), 8-12. Retrieved from http://www.readwritethink.org/files/ resources/lesson_images/lesson1140/VM0103What.pdf

Hepple, E., Sockhill, M., Tan, A., \& Alford, J. (2014). Multiliteracies pedagogy: Creating claymations with adolescent, post-beginner English language learners. Journal of Adolescent \& Adult Literacy, 58(3), 219-229. doi: 10.1002/jaal.339

Hodge, R., \& Kress, G. (1988). Social semiotics. New York, NY: Cornell University Press.

Horsford, S. D., \& Sampson, C. (2013). High-ELL-growth states: Expanding funding equity and opportunity for English language learners. Voices in Urban Education, 37, 47-54. Retrieved from http://vue.annenberginstitute.org/sites/default/files/issuePDF/VUE37.pdf 
International Reading Association. (2012). Adolescent literacy: A position statement of the International Literacy Association. Retrieved from https://www.ttac.vt.edu/content/dam/ttac_vt_edu/Adolescent_Literacy_Pos ition.pdf

James, W. (1902). The principles of psychology. New York, NY: Henry Holt.

Jenkins, H. (2006). Convergence culture: When old and new media collide. New York, NY: University Press.

Jewitt, C. (2003). Re-thinking assessment: Multimodality, literacy and computermediated learning. Assessment in Education, 10(1), 84-102.

Jewitt, C. (2008). Multimodal discourses across the curriculum. In M. MartinJones, A. M. de Mejia, \& N. Hornberger (Eds.), Encyclopedia of language and education: Discourse and education (pp. 357-367). Boston, MA: Springer.

Jewitt, C., \& Kress, G. (2003). Multimodal literacy. New York, NY: Peter Lang.

John-Steiner, V., \& Mahn, H. (1996). Sociocultural approaches to learning and development: A Vygotskian framework. Educational Psychologist, 31(3/4), 191-206.

Kanno, Y. (2003). Negotiating bilingual and bicultural identities: Japanese returnees.betwixt two worlds. Mahwah, NJ: Lawrence Erlbaum.

Kentucky Center for Economic Policy (2014). A profile of new Americans in Kentucky. Retrieved from http://kypolicy.org/dash/wpcontent/uploads/2014/07/New-Americans-in-Kentucky-2.pdf

Kentucky Department of Education. (2016). Administrative Regulation: 703 KAR 5:070. Retrieved from http://education.ky.gov/districts/legal/Documents/ 703\%20KAR\%205070.pdf

Kentucky Refugee Ministries. (2015). Retrieved August 17, 2017 from https://kyrm.org/services/esl-cultural-orientation/ /

Kissau, S., Adams, M. J., \& Algozzine, B. (2015). Middle school foreign language instruction: A missed opportunity? Foreign Language Annals 48(2), 284303.

Krashen, S. (1982). Principles and practice in second language acquisition. Retrieved from http://www.sdkrashen.com/content/books/ principles_and_practice.pdf

Kress, G. (2009). Multimodality: A social semiotic approach to contemporary communication. London, UK: Routledge. 
Kress, G., \& Jewitt, C. (2003). Introduction. In C. Jewitt \& G. Kress (Eds.), Multimodal literacy (pp. 1-18). New York: Peter Lang.

Leland, C. \& Harste, J. (1994). Multiple ways of knowing: Curriculum in a new key. Language Arts, 71(5), 337-345. Retrieved from http://www.jstor.org/stable/41961975

Kress, G., \& van Leeuwen, T. (1996). Reading images: The grammar of visual design. New York, NY: Routledge.

LCSI (2014). Microworlds [Computer Software]. Retrieved from http://www.microworlds.com/solutions/

Linden Lab (2003). The Second Life Virtual World [Video Game]. Retrieved from https://join.secondlife.com/?lang=en-US

Loerts, T. (2013). Multimodal literacy learning opportunities in one grade six classroom: Possibilities and constraints. (Doctoral dissertation). Retrieved from http://ir.lib.uwo.ca/cgi/viewcontent.cgi?article=3106\&context=etd

Maxwell, J. A. (2005). Qualitative research design: An interactive approach (2nd ed.). Thousand Oaks, CA: Sage.

McArdle, F., \& Boldt, G. (2013). Young children pedagogy and the arts: Ways of seeing. New York, NY: Routledge.

Mead, G. (1934). Mind, self, and society: From the standpoint of a social behaviorist. Chicago, IL: University of Chicago Press.

Merriam, S. B. (2009). Qualitative research: A guide to design and implementation. San Francisco, CA: Jossey-Bass.

Moje, E., \& Luke, A. (2009). Literacy and identity: Examining the metaphors in history and contemporary research. Reading Research Quarterly. 44(4), 415-437. Retrieved from http://www.jstor.org/stable/25655467

Moje, E., Overby, M., Tysvaer, N., \& Morris, K. (2008). The complex world of adolescent literacies: Myths, motivations, and mysteries. Harvard Educational Review, 78(1), 107-154.

Moll, L. (2014). L. S. Vygotsky and education. New York, NY: Routledge.

Moll, L. C., Amanti, C., Neff, D., \& Gonzalez, N. (1992). Funds of knowledge for teaching: Using a qualitative approach to connect homes and classrooms. Theory into practice, 31(2), 132-141.

National Center for Education Statistics (2003). National assessment for adult literacy (NAAL). Retrieved from https://nces.ed.gov/naal/fr_definition.asp 
National Council for Teacher Education (2005). NCTE Position Statement on Multimodal Literacies. Retrieved from http://www.ncte.org/positions/statements/multimodalliteracies

National Council for Teacher Education (2013). The NCTE Definition of 21st Century Literacies. Retrieved from http://www.ncte.org/positions/statements/21stcentdefinition

Newfield, D. (2011). Multimodality and children's participation in classrooms: Instances of research. Perspectives in Education. 27-35.

No Child Left Behind Act of 2001, P.L. 107-110, 20 U.S.C. § 6319 (2002).

Norton, B. (1997). Language, identity, and the ownership of English. TESOL Quarterly, 31(3), 409-429.

Norton, B. (2003). The motivating power of comic books: Insights from Archie comic readers. The Reading Teacher, 57(2), 140-147.

Norton, B. (2006). Identity as a sociocultural construct in second language education. In K. Cadman \& K. O'Regan (Eds.), TESOL in Context [Special Issue]. (pp. 22-33). Retrieved from http://faculty.educ.ubc.ca/norton/Norton\%202006\%20in\%20Australia\%20T ESOL.pdf

Norton, B. (2010). Identity, literacy, and English-language teaching. TESL Canada Journal, 28(1), 1-14.

Norton, B., \& Toohey, K. (2011). Identity, language, learning, and social change. Language Teaching, 44(4), 412-446.

Norton, B., \& Williams, C. J. (2012). Digital identities, student investments and eGranary as a placed resource. Language and Education, 26(4), 315329.

Ntelioglou, B., Fannin, J., Montanera, M., \& Cummins, J. (2014). A multilingual and multimodal approach to literacy teaching and learning in urban education: a collaborative inquiry project in an inner city elementary school. Frontiers in Psychology, 5, 1-10. doi: 10.3389/fpsyg.2014.00533

Olshansky, B. (2008). The power of pictures: Creating pathways to literacy through art. San Francisco, CA: Jossey-Bass.

Olshansky, B. (2016). Time for a paradigm shift: Recognizing the critical role of pictures within literacy learning. Occasional Paper Series, 2014 (31). Retrieved from http://educate.bankstreet.edu/occasional-paperseries/vol2014/iss31/10/ 
Pavlenko, A., \& Lantolf, J. P. (2000) Second language learning as participation and the (re)construction of selves. In J. P. Lantolf (Ed.), Sociocultural theory and second language learning (pp. 155-177). Oxford, England: Oxford University Press.

Pekrun, R. (2006). The control-value theory of achievement emotions: Assumptions, corollaries, and implications for educational research and practice. Educational Psychology Review, 18(4), 315-341. doi:10.1007/s10648-006-9029-9

Pekrun, R., \& Linnenbrink-Garcia, L. (2012). Academic emotions and student engagement. In S. L. Christenson, A. L. Reschly, \& C. Wylie (Eds.), Handbook of research on student engagement (pp. 259-282). New York, NY: Springer.

Pekrun, R. (2014). Emotions and learning (Educational Practices Series 24). Switzerland: UNESCO International Bureau of Education.

Pekrun, R., Frenzel, A., Goetz, T., \& Perry, R. P. (2007). The control-value theory of achievement emotions: An integrative approach to emotions in education. In P. A. Schutz \& R. Pekrun (Eds.), Emotion in education (pp. 13-36). San Diego, CA: Academic Press.

Penn Hill Group (2016). Notice of Proposed Rulemaking on ESSA Accountability and State Plans. Retrieved from http://www.ccsso.org/Documents/2016/ ESSA/CCSSOMemoESSAProposedRegulationsAccountabilityReport CardsStatePlans6116.pdf

Ranker, J. (2009). Redesigning and transforming: A case study of the role of semiotic import in early composing processes. Journal of Early Childhood Literacy, 9(3), 319-347.

Scherer, K. (2005). What are emotions? And how can they be measured? Social Science Information, 44(4), 695-729.

Schutz, P. A., \& Pekrun, R. E. (2007). Emotion in education. San Diego, CA: Academic Press.

Sousa, D. (2011). How the ELL brain learns. Thousand Oaks, CA: Corwin.

Stein, P. (2000). Rethinking resources: Multimodal pedagogies in the ESL classroom. TESOL Quarterly 34(2), 333-336. Retrieved from http://www.jstor.org.echo.louisville.edu/stable/pdf/3587958.pdf?_=146687 5178090

Sunstein, B., \& Chiseri-Strater, E. (2012). Fieldworking: reading and writing research. (4th ed.) Boston, MA: Bedford/St. Martin's Press. 
Sylwester, R. (1994). How emotions affect learning. Educational Leadership, 52(2), 60.

The Executive Office of the President. (2015). Giving Every Child a Fair Shot: Ensuring All Students Have Equal Opportunity to Succeed. Retrieved from https://www.whitehouse.gov/sites/default/files/docs/esea_white_house_re port_.pdf

Tierney, R. J., Bond, E., \& Bresler, J. (2006). Examining literate lives as students engage with multiple literacies. Theory Into Practice, 45(4), 359-367.

Unrau, N. J., \& Alvermann, D. E. (2013). Literacies and their investigation through theories and models. In D. E. Alvermann, N. J. Unrau, \& R. B. Ruddell (Eds.), Theoretical models and processes of reading (6th edition, pp. 4-90). Newark, DE: International Reading Association. Retrieved from http://www.academia.edu/25728615/

Literacies_and_their_Investigation_through_Theories_and_Models

U.S. Department of Justice \& U.S. Department of Education. (2015). Dear colleague letter: English learner students and limited English proficient parents. Retrieved from http://www2.ed.gov/about/offices/list/ocr/letters/ colleague-el-201501.pdf

Vagan, A. (2011). Towards a sociocultural perspective on identity formation in education. Mind, Culture, and Activity, 18, 43-57.

Vagle, M. (2014). Crafting phenomenological research. Walnut Creek, CA: Left Coast Press.

Vincent, J. (2006). Children writing: Multimodality and assessment in the writing classroom. Literacy 40(1), 51-57. Retrieved from http://onlinelibrary. wiley.com.echo.louisville.edu/doi/10.1111/j.14679345.2006.00426.x/epdf

Vygotsky, L. S. (1978). Mind in society: The development of higher psychological processes. (M. Cole, V. John-Steiner, S. Scribner, \& E. Souberman, Eds.). Cambridge, MA: Harvard University Press. (Original manuscripts 1930-1934). Retrieved from http://www.cles.mlc.edu.tw/ cerntcu/099curriculum/Edu_Psy/EP_03_New.pdf

Walsh, M. (2009). Pedagogic potentials of multimodal literacy. In L. Tan \& R.Subramaniam (Eds.), Handbook of research on new media literacy at the K-12 level: Issues and challenges. Hershey, PA: Information Science Reference.

Walsh, M. (2010). Multimodal literacy: What does it mean for classroom practice? Australian Journal of Language and Literacy, 33(3), 211-239. 
Wei, Li (2011). Multilinguality, multimodality, and multicompetence: Code- and modeswitching by minority ethnic children in complementary schools. The Modern Language Journal, 95(3), 370-384. doi: 10.1111/j.15404781.2011.01209

WIDA. (2012). 2012 Amplification of the English language development standards: Kindergarten-grade 12. Retrieved from https://www.wida.us/standards/eld.aspx

WIDA. (2017). SPRING 2017 interpretive guide for score reports kindergartengrade 12. Retrieved from https://www.wida.us/assessment/ACCESS20.aspx

Williams, L. (1983). Teaching for the two-sided mind. Englewood Cliffs, NJ: Prentice-Hall.

Wilson, A., Chavez, K., \& Anders, P. (2012). "From the Koran and family guy": Expressions of identity in English learners' digital podcasts. Journal of Adolescent \& Adult Literacy. 55(5), 374-384.

Wiseman, A., Makinen, M., \& Kupiainen, R. (2015). Literacy through photography: Multimodal and visual literacy in a third grade classroom. Early Childhood Education 44, 537-544. doi: 10.1007/s10643-015-0739-9

Zacarian, D. (2012). Serving English learners: Laws, policies, and regulations. Retrieved from http://www.colorincolorado.org/sites/default/ files/Policy_Guide_Final.pdf 


\section{APPENDIX A: STUDENT INTERVIEW QUESTIONS}

\section{Initial Semi-structured Student Interview Questions}

1. Tell me about yourself:

a. What is your name? What languages do you speak? How long have you been in the United States? Did you go to school in your home country?

b. Can you read and write in your native language?

c. What do you like to do outside school?

2. How do you feel about writing?

3. How comfortable are you with writing in English?

4. What are your favorite writing activities? What is your favorite type of writing?

5. Do you write outside of school?

6. What makes writing in English difficult for you?

7. What makes writing in English easy for you?

8. How comfortable are you with collage?

9. Do you like to work on the assignments that include collage? Why and why not?

10.What is the most recent assignment you worked on that included the arts?

11.Do you engage in the arts outside of school time? 


\section{Follow-up Student Interview Questions:}

1. How do you feel about writing now?

2. How do you feel about the arts now?

3. What strategies or activities in the unit were helpful and why?

4. What strategies or activities were challenging and why?

5. Describe your experience with the arts? Describe your experience with writing?

6. How did the experience make you feel?

7. What have you learned from this experience? 


\section{APPENDIX B: TEACHER INTERVIEW QUESTIONS}

\section{Initial Semi-structured Teacher Interview Questions:}

1. Tell me about yourself and your professional history:

a. What are you certified to teach?

b. How long have you been teaching?

2. Tell me about your experience with the writing process as a student first and then as a teacher.

a. Do you consider yourself a good writer? If so, what makes you a good writer?

b. How often do you write?

3. Tell me about your experience with the arts as a student first and then as a teacher.

4. Tell me about your students.

a. What do you know about their writing strengths and weaknesses?

b. What do you know about their experiences with the arts?

5. How often do you incorporate writing into your teaching? For what purpose?

6. How often do you incorporate the arts into your teaching? For what purpose?

7. What strategies and activities have you used to help your students with writing? How successful or unsuccessful were these strategies? What do 
you hope your students will gain from participating in this unit? What are your goals for your students?

\section{Follow-up Teacher Interview Questions:}

1. Do you think you have accomplished the goals you had set for you and your students? Why and why not?

2. How comfortable are you with incorporating the arts into your teaching now?

3. In your opinion, what role did the arts play in the student learning?

4. How do you feel about integrating the arts into your teaching now?

5. If you were to do this unit again, what would you do differently? What would you keep the same? 
APPENDIX C: ORGANIZATION OF VISUAL TEXTS (Albers, 2007)

Images used:

- Photos

- Magazine pictures

Type of visual text structure:

- Aesthetic

- Metaphoric

- Narrative

- Narrative text structure:

o Schematic

o Descriptive

o Multiphasic

\section{Color:}

- Cool colors

- Warm colors

Lines: 


\section{Shapes:}

\section{Composition:}

\section{Orientation:}

- Vertical orientation: information is displayed in the upper and lower two quadrants (image is read from top to bottom).

\begin{tabular}{|l|l|}
\hline Ideal & Ideal \\
\hline Real & Real \\
\hline
\end{tabular}

- Horizontal Orientation: information is displayed in the left top and bottom quadrants and he right top and bottom quadrants (image is read from left to right).

\begin{tabular}{|l|l|}
\hline Known & New \\
\hline Known & New \\
\hline
\end{tabular}

\section{Comments:}


APPENDIX D: CODES

ELLs' Feelings about Collage-Making Activity

- enjoyed

- felt happy

- liked the most

- collage was fun

- felt good

\section{ELLs' Feeling about Writing Activity}

- didn't like writing

- hate writing

How ELLs Experienced Collage-Making Activity

- wanted to be alone

- didn't want to talk

- time went fast

- it was emotional

- made think

- could use whatever wanted

- knew strategies to organize

- easier than writing

- couldn't draw

How ELLs Experienced Writing Activity

- writing was hard

- a lot of work

- expressed more through writing

- not hard (if pick the right topic)

- know what l'm doing

Feelings Evoked by the Topics of Collages

- upset

- sad

- sad and happy

- not happy 
- scared

How Collage Helped ELLs (Intrinsic and Extrinsic Values)

- helped remember details

- brought back memories

- helped recollect past

- brought back feelings

- helped express feelings

- allowed to be creative

How Writing Helped ELLs (Intrinsic and Extrinsic Values)

- helped express myself

- helped describe things

- helped get ready for high school 


\section{CURRICULUM VITAE}

NAME:

ADDRESS:

DOB:

EDUCATION:
Irina V. McGrath

1815 Warrington Way

Louisville, KY 40222

502-614-0125

Irina.mcg11@gmail.com

St. Petersburg, Russia - April 9, 1971

M.A., English and French

Kuban State University

1993

M.A., Reading Education

University of Louisville

2012

ED.S. Educational Administration

University of Louisville

Anticipated 2018

Ph.D., Curriculum and Instruction

University of Louisville

CERTIFICATIONS: Endorsement for Literacy Specialist, All Grades

Endorsement for Teaching English as Second Language, All

Grades

Professional Certificate for Teaching French, All Grades

Approval for English Program Consultant

Approval for ESL Program Consultant

TEACHING

EXPERIENCE: Graduate School:

EDAP 642 Literacy and Cultural Differences

EDAP 638 Instructional Strategies for Diverse Learners

EDAP 521 Teaching English Learners

Middle School:

English as a Second Language (ESL), $6-8^{\text {th }}$ grades 


\section{EMPLOYMENT:}

ESL Middle School Resource Teacher

$$
2008 \text { - Present }
$$

* Support teachers in effectively planning and presenting effective lessons

* Provide professional development to teachers

* Present ESL professional development to individual district school

- Provide assistance to teachers and staff in the area of effective instructional and class management techniques.

* Model research-based ESL literacy instruction

University of Louisville Part-Time Instructor

2007 - Present

* Trained with the University of Louisville Delphi Center to design, online courses.

* Taught online and face-to-face courses: EDAP 642, EDAP 638, and EDAP 521.

ESL Middle School Teacher

$$
2002-2008
$$

* Successfully taught Language Arts and Reading to $6^{\text {th }}-8^{\text {th }}$ grade ESL students

* Managed a 6-8 ESL curriculum

* Consistently demonstrated significant LA \& reading gains via state tests while reaching proficiency on state assessments

Thomas Jefferson Middle Literacy Lead

$$
2006-2008
$$

* School contact person for JCPS District Reading Personnel and Instructional Coaches

* Implemented plan to successfully monitor illiteracy interventions

* Tracked student progress and collected and analyzed reading data to develop instruction

\section{OTHER RELATED EXPERIENCE:}

National Writing Project (NWP)

$$
2007-2012
$$

Urban Sites Network Leadership Team

- Participated in NWP USN Meetings and initiatives to strengthen urban writing projects, to support and sustain diverse teacher leadership pools, to support needs of teachers in urban schools

* Facilitated NWP USN workshops.

Louisville Writing Project (LWP XXV)

$$
2005 \text { - Present }
$$

* Organize LWP mini-conferences: contact possible presenters, create schedules, create brochures, and advertise the conferences

* Headed the National Writing Project Urban Sites Conference in Louisville, KY

Facilitated ELL Academies 
Adelante Hispanic Achievers Program

2007 - Present

Executive Board Member

* Worked to provide support to assist personal, social, cultural, and educational success

* Facilitated workshops

\section{NATIONAL PRESENTATIONS:}

McGrath, I., \& Dunn, T. (2017). Writing narratives with ELLs. Conference Presentation at SETESOL.

Patton, E., \& McGrath, I. (2017). Connecting the dots: Helping ESL teachers translate theory to practice. Conference Presentation at KYTESOL.

McGrath, I. (2015). Narrative writing through co-teaching. Conference Presentation at Louisville Writing Project mini-conference.

McGrath, I. (2015). Understanding Danielson's Domains 2 and 3. Conference Presentation at Louisville Writing Project mini-conference.

Wolph, J., Howell, P., McGrath, I., Burger, M. (2015). Multiple sessions facilitated for the UofL-LWP Adolescent Literacy Project.

McGrath, A. (2014). Prepare English learners to be college- and career-ready! Professional Development Workshop delivered for Kentucky teachers, Louisville, KY

McGrath, I., \& Dinkins, E. (2014). Building knowledge through collaboration: Expertise, expectations, and communication. Conference Keynote. KYTESOL.

McGrath, I. (2014). The art of writing narratives with English language learners. Conference Presentation at Kentucky Writing Project State Network Conference.

McGrath, I., Kraemer, J., \& Shory, M. (2014). Effective professional learning through lesson study. Conference Presentation at WIDA 2014 National Conference.

McGrath, I. (2009). Professional tools: Digging in to the Literacy PERKS tool for developing a schoolwide plan. Conference Presentation at Kentucky Writing Project Fall Conference.

\section{PUBLICATIONS:}

Chisholm, J. S., Whitmore, K. F., Shelton, A., \& McGrath, I. (2016). Moving interpretations: Using drama-based arts strategies to deepen learning about The Diary of a Young Girl. English Journal, 105(5), 35-41. 


\section{EVALUATION REPORT:}

Chisholm, J. S., Whitmore, K. F., Shelton, A., McGrath, I., \& Ousley, C. (2015, May). Anne Frank: Bearing Witness. Executive Summary and Evaluation Report submitted to Jeffrey Jamner, Senior Director, School Programs, The Kentucky Center for the Performing Arts.

\section{NATIONAL CONFERENCE PRESENTATIONS: (PEER-REVIEWED)}

Whitmore, K. F., Chisholm, J. S., Joiner, K., Whittaker, F., Shelton, A., \& McGrath, I. (2016, November). Integrating the arts to layer embodied and empathetic literacies: Middle school learners read Anne Frank. Paper presented at the meeting of the National Council of Teachers of English, Atlanta, GA.

Chisholm, J. S., Whitmore, K. F., McGrath, I., \& Shelton, A. (2015, February). Using arts-based literacies to develop, embody, and transmediate empathy in middle grades ELA classrooms. Paper presented at the meeting of the Journal of Language and Literacy Education, Athens, GA. 